\title{
THE VEIL OF MODERNITY \\ HERITAGE PRESERVATION IN TORONTO'S LIBERTY VILLAGE
}

\author{
By \\ Vedrana Maric
}

A thesis submitted to the Faculty of Graduate and Postdoctoral Affairs in partial fulfillment of the requirements for the degree of

Master of Architecture

Carleton University

Ottawa, Ontario

(C) 2014

Vedrana Maric 


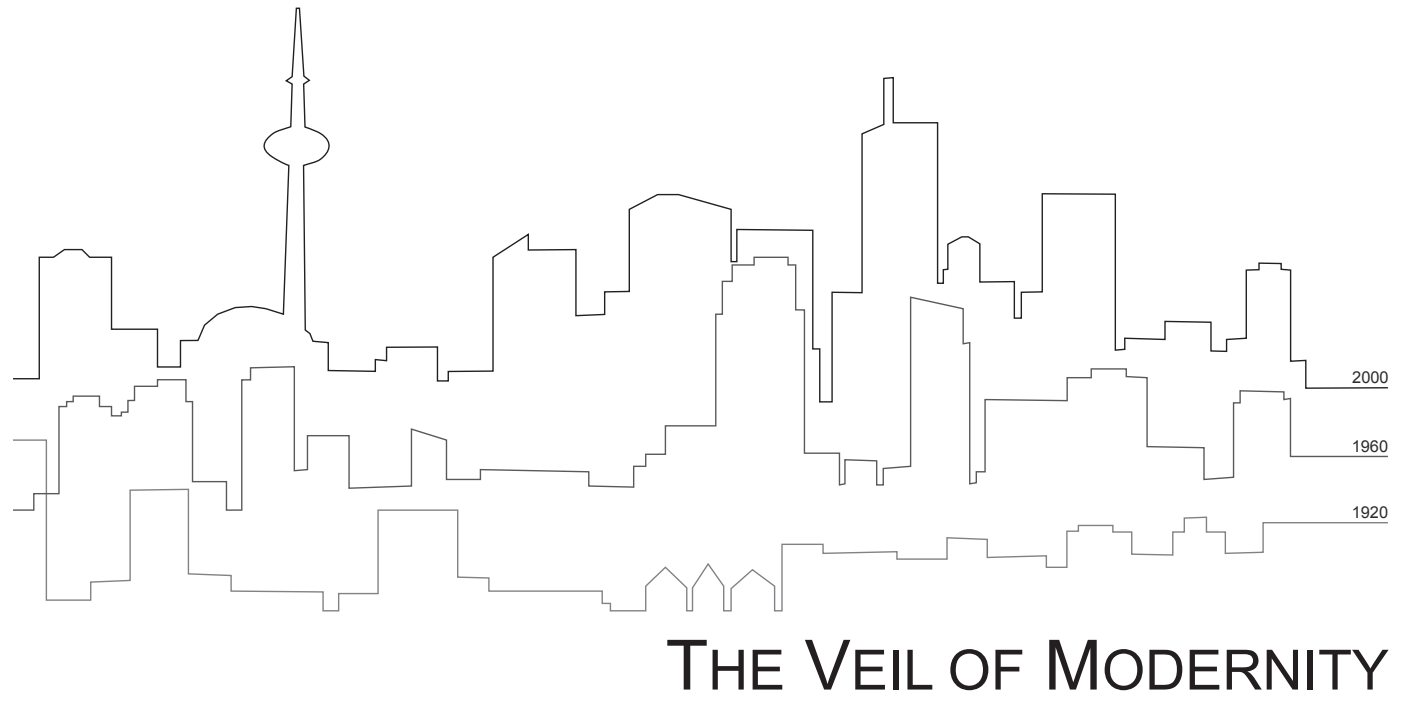
HERITAGE PRESERVATION IN TORONTO'S LIBERTY VILLAGE 


\begin{abstract}
Through etymological interpretations and a study of architectural roots, this thesis will propose a modern intervention to a historically rich component of Toronto's urban fabric. Architects are often faced with the dilemma of translating heritage as a continuum extending beyond our past and into our future. Strategies for creating an architectural palimpsest can be applied to modern construction and methodology as the architect creates a contemporary dialogue with the urban landscape.

The dichotomy presented between the grounding truth of the authentic and the fleeting temporality of the modern in architecture will play a key role in developing a program and contemporary intervention to the Toronto Central Prison Chapel. Located in the highly developed east end in Liberty Village, this thesis will propose a design strategy that will link Toronto's founding architectural language to the ever changing needs of the modern individual. The proposed design will serve as framework to embrace the collective and cultural past of the city while preserving and adapting the Prison Chapel to suit contemporary needs of the residents of Liberty Village.
\end{abstract}




\title{
Table of Contents
}

\author{
i Abstract \\ ii Table of Contents \\ iv Introduction: Translating Architecture \\ $1 \quad$ Chapter 1: The Authentic \\ 2 Defining authenticity \\ $4 \quad$ Authenticity in Historical Discourse \\ 7 Authenticity in Architectural Discourse \\ 9 Re-appropriating memory
}

13 Chapter 2: The Modern

14 Defining the Modern

15 Modernity as the Fleeting

18 The Destructive Character

21 Chapter 3: Situating the Chapel

24 Industrial Development and Urban Growth

27 Liberty Village

40 Toronto Central Prison Chapel

47 Chapter 4: The Veil of Modernity

73 Conclusion

74 Bibliography

76 List of Illustrations

$77 \quad$ Appendices 


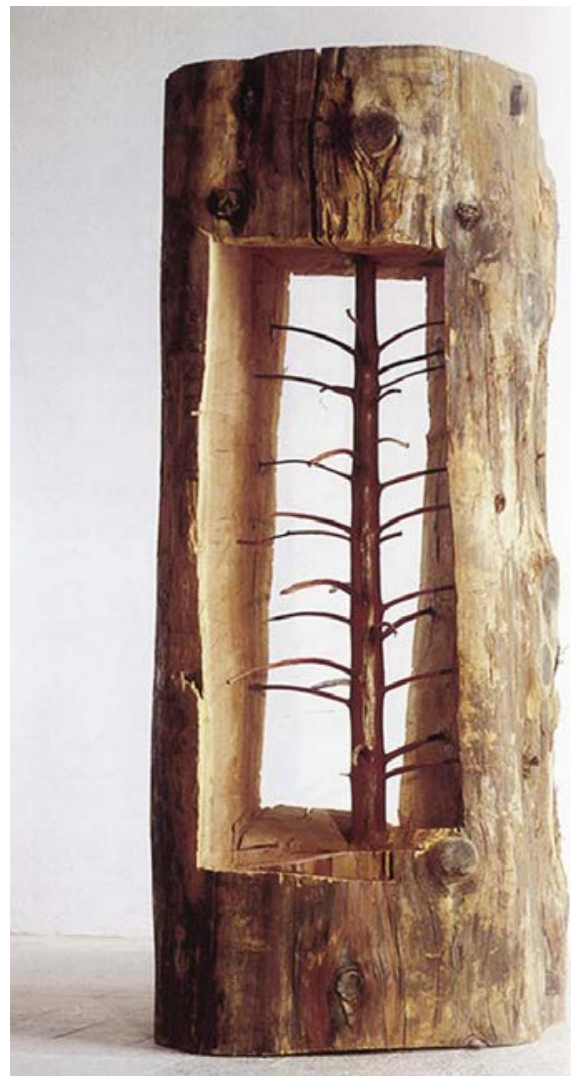

IMAGE 1 . Wood carving
"My artwork shows, with the language of sculpture, the essence of matter and tries to reveal with the work the hidden life within."

Italian artist Guiseppe Penone in The Hidden Life Within, 2011 


\section{INTRODUCTION | TRANSLATING ARCHITECTURE}

Through evolution of language, the original meaning of words takes form and adapts over time into the words we use today. A definition is tied to a combination

of letters in any language yet modern meaning offers only a superficial understanding of the word's significance. It is only by tracing back a word through its history that it translates into a story and offers insight into the deeper meaning and understanding of present conditions. Taken at face value, a word, as many other things, will limit ones knowledge and by extension their creative potential. It is through understanding of origins that a word becomes a story.

"What does language communicate? It communicates the mental being corresponding to it. [...] Mental being communicates itself in, not through, a language, which means that it is not outwardly identical with linguistic being [...] What is communicable in a mental entity is its linguistic entity. Language therefore communicates the particular linguistic being of things, but their mental being only insofar as this is directly included in their linguistic being, insofar as it is capable of being communicated."

In his short essay On Language as Such and on the Language of Man, Walter Benjamin differentiates between the conventional acceptances of meaning in language today and the essence of the original language. Language as we know it is a weakened derivative of an original language man created using the concept of mimesis, meaning an imitation or reproduction of the real - In using the term language,
Benjamin refers to all
communication of the contents
of the mind. All expression of
life is a kind of language that
communicates meaning. This
thesis will henceforth use this
meaning of the word. world. Benjamin distinguishes the mimetic dimension as the basis of language, a language which was created by naming things on the basis of similarities between the 
thing or person and the name attributed to it. This mimetic structure which lends itself to the origins of language is often no longer pronounced and recognizable in the words we use today, but no matter how altered this structure supports the foundation of language and meaning behind it.

Drawing parallels to language, modern architecture reflects this detachment between contemporary and origins. Present day architecture that is created to replace or inhabit the existing in order to adapt to present day needs is often a product of distraction rather than contemplation. In today's "surreal materialist culture", the emphasis on newness is not a product of aesthetic and artistic value but rather one of consumption and novelty in a futuristic bias. ${ }^{2}$ Modern architecture is largely influenced by this bias, as the positive reception of new, shiny and impressive architectural imagery takes precedent over the continuum of culture and tradition.

The qualities inherent in architectural remnants allow for a richer interpretation of a city's memory and play an integral part in shaping its future. Alongside the written and visual arts, architecture makes up the most significant externalization of human memory. ${ }^{3}$ These remnants are physical expressions of a city's founding language, one which created the foundation of the architectural fabric we see today. The same concept of mimesis that is applied to language can be seen in architecture, as built form is used as a mnemonic device to materialize time and concretize remembrance.

"Buildings project epic narratives." -Juhani Pallasmaa in Space, Place, Memory and Imagination, 2007 
The first intent of this thesis will be to establish the importance and role of authenticity in architecture through its elaboration as a moral and subjective ideal. Walter Benjamin's notion of aura and Charles Taylor's interpretation of common space will be presented as significant authenticating sources. This thesis will build upon the idea that these elements are critical in architectural discourse on heritage preservation and its role in nation building. The next step will introduce modernity in the words of Charles Baudelaire as "the transitory, the fugitive [and] the contingent." This will inform the notion of modernity as a perpetual cycle of destruction and rebirth, which in turn is an integral part of self-identity.

The site chosen for this thesis project is located in Liberty Village, a master-planned community in Toronto's west side which combines residential, commercial and retail uses. The Central Prison Chapel is a small heritage brick building that has survived since Toronto's beginnings as an industrial port city and currently stands vacant among a sea of glass-clad condominims. This thesis will present authenticity and modernity as opposing notions and elaborate on their understanding in order to propose a design intervention in which both concepts can co-exist. 


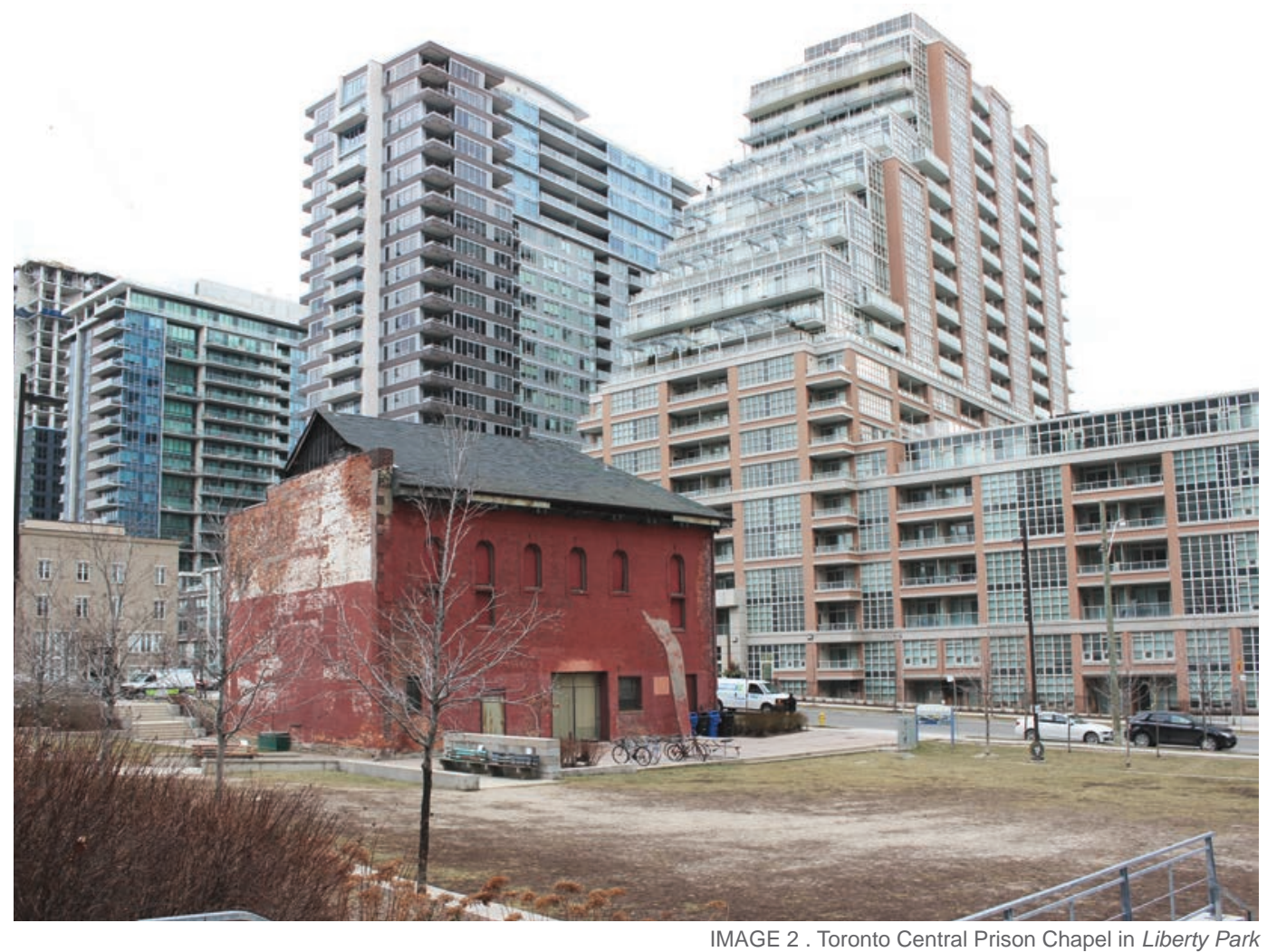


Chapter 1: The Authentic

\author{
au•then•tic \\ adjective \\ 1. \\ real or genuine: not copied or false \\ $\downarrow$ Greek Origins \\ auton $+\quad$ thetos \\ as "self" as "thesis \\ self authenticity as a means of self positing
}




\section{1 | Defining Authenticity}

In today's common definition of the word, authenticity is bestowed as a state of ontological superiority produced by origins - that which is authentic is presumed to be more real than that which is imitative. This desire for the real reflects the notion of authenticity as an ideal which reveals reality without the pretext of misconceptions and any form of artifice. Benjamin states that "the presence of the original is prerequisite to the concept of authenticity," ${ }^{4}$ implying that there is an essential connection between a phenomena and its original, authenticating, source. A certain privilege is assumed by authentic phenomena, given by its author or by an authenticating source. However the question then becomes the validity of this authenticating source: how much legitimacy should be attributed to this source, and why?

The introduction of Malcolm Gladwell's book Blink: The Power of Thinking Without Thinking speaks of a marble statue that was acquired and bought by the J. Paul Getty Museum in 1983 for $\$ 10$ million. After a thorough investigation, the statue appeared to be consistent with other known kouroi, and a scientific analysis revealed that the material which it consisted of indicated that the statue was not a contemporary fake. Documents pertaining to its authenticity were provided, and yet despite all these factors, many scholars did not believe that the sculpture was authentic. When Evelyn Harrison, one of the world's

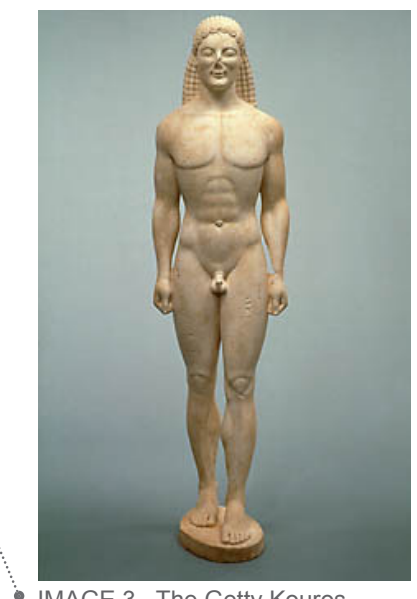
foremost experts on Greek sculpture was invited to see it, it was said that she had a "hunch, an instinctive sense that something was amiss." ${ }^{5}$ The same is said of Thomas Hoving, former director of the Metropolitan Museum of Art in New York, whose first instinct about the statue was 
that it was fresh, and Angelos Delivorrias, director of the Benaki Museum in Athens, who felt "a wave of intuitive repulsion" ${ }^{6}$ as he first laid eyes on it. Since there was no physical evidence, the authenticity of the statue was widely debated until gradually the documents of authentication proved to be forgeries. Further testing revealed that the sculpture was in fact a pastiche of several different styles from different places and periods, and that the surface of the stone could very easily have been aged manually in a matter of months.

What is it about this work that made certain experts refute its legitimacy at first glance? In his book Gladwell seeks to explain the strength of the adaptive unconscious and intuitive judgment. However through a study of the viewer rather than the object, Gladwell fails to credit the power of the statue itself in producing an instant recognition of authenticity to the observer. In the scope of authenticity in art, Benjamin introduces the notion of the aura, stating that "the authenticity of a thing is the essence of all that is transmissible from its beginning, ranging from its substantive duration to its testimony to the history which it has experienced." ${ }^{8}$ In The Work of Art in the Age of Mechanical Reproduction, Benjamin attributes an atmosphere or quality to a phenomena that is unique to itself, which no reproduction could emulate. Though he recognizes the reality of artistic reproduction and its social significance, Benjamin suggests that mechanized reproduction results in a "tremendous shattering of tradition" defined as an incapacity to participate in the aesthetics and politics of earlier times (of the original) that are embedded within that traditional process of production. "The uniqueness of a work of art is inseparable from its being imbedded in the fabric of tradition," 10 thus production that occurs outside of tradition does not hold this aura. An authentic source will always contain this aura.

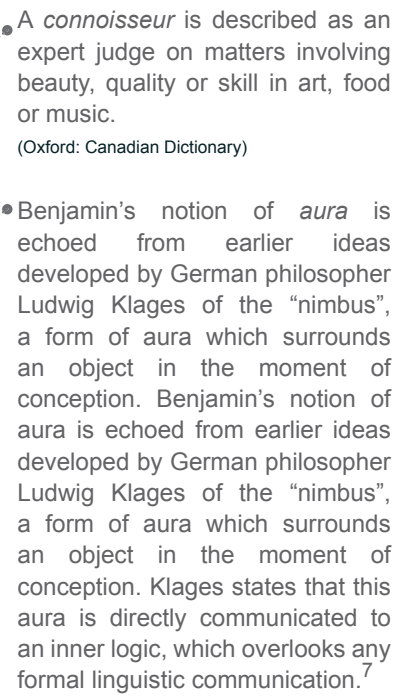
expert judge on matters involving beauty, quality or skill in art, food or music.

(Oxford: Canadian Dictionary)

- Benjamin's notion of aura is echoed from earlier ideas developed by German philosopher Ludwig Klages of the "nimbus", a form of aura which surrounds an object in the moment of conception. Benjamin's notion of aura is echoed from earlier ideas developed by German philosopher Ludwig Klages of the "nimbus", a form of aura which surrounds an object in the moment of conception. Klages states that this aura is directly communicated to an inner logic, which overlooks any formal linguistic communication. ${ }^{7}$ 


\section{2 | AUTHENTICITY IN HISTORICAL Discourse}

In historical discourse, questions of authenticity arise in a wide range of concepts; from the interpretation of one's self to the reality and significance of an object. The etymology of the word authenticity can be traced to the Greek roots auton, meaning self as the author, and thetos, meaning thesis, or the notion of one's true self. ${ }^{11}$ This self-actuality and authenticity has been explored by many philosophers and theorists, and though their views may vary there is a common general understanding of the importance of the individuals' reaction to the outside world and influences in order to define personal authenticity.

Jean-Jacques Rousseau was perhaps the first to elaborate the role of social pressures on the romanticized ideal of being one's true self in The Social Contract in 1762. He states that the concept of authenticity is connected with one's acceptance of inner motives in the valuation of moral worth of one's actions. It is only when one's moral guidance becomes the sole source for normativity that his or her identity is deemed authentic. ${ }^{12}$ Le sentiment de l'existence is a term coined by Rousseau describing the contentment felt through authentic reflection of oneself. It is Rousseau's belief that this contentment is more fundamental than any moral view. ${ }^{13}$

This emphasis on social norms as a formative constituent of man is accepted but rephrased later by Friedrich Nietzsche, whose view on self-authenticity relies on elevating oneself above conventional ideas of morality and faith. He opposes the role of religion as a tool for self-positing because he believes in shaping ones beliefs without the use of virtues which can cloud judgement. According to Nietzsche, in order for man to 
achieve true authenticity, he must elevate himself over such conventional ideas of morality and faith, and shape his beliefs according to his own personal ethics. In the process of realizing the nature of one's existence and identity, their authenticity, i.e. what is real, becomes subjective to its creator. "If Nietzsche made us aware of anything in ethics, it is the importance of perspectives, the need to see all concepts and values in context." ${ }^{14}$

The search for authenticity as a mode of selfdefinition provides a grounding truth in a world of fleeting phenomena. In the absence of an external universal frame of reference, individualism has become the gateway to one's moral compass, and thus their authenticity. Reflecting on authenticity as a moral issue, Charles Taylor in The Malaise of Modernity states that "before the late 18th century, no one thought that the differences between human beings had this kind of moral significance. There is a certain way of being human that is my way. I am called upon to live my life in this way, and not in imitation of anyone else's life." ${ }^{15}$ Taylor promotes the notion that authenticity is an ideal and a goal to be attained. Contradicting Nietzschean schools of thought, Taylor goes on to say that the authenticity we derive cannot come from within, as man's understanding of "[his] own identity depends on [his] dialogical relations with others," ${ }^{16}$ that our identity is shaped by communication with the outside world. 
This notion of the social realm as a formative element of identity is what Charles Taylor calls the public sphere, where democratic space provides the framework for developing our authenticity. A central feature of modern society is "common space in which the members of society are deemed to meet through a variety of media: print, electronic, and also face-to-face encounters; to discuss matters of common interest; and thus be able to form a common mind about these. ${ }^{17}$ In this modern public sphere, Charles Taylor describe its constituents, i.e. modern people, as a unified group of members of equal value whose common consensus emerges from rational, critical debate.

This thesis will build upon the idea that common space is critical for addressing the concept of authenticity. 


\section{3 | AUthENTICITY IN ARCHITECTURAL Discourse}

"Authenticity is in practice never absolute, always relative"

- David Lowenthal in Changing Criteria in Authenticity, 2008

The concept of authenticity as a deciding factor in identity and collective memory has been an important topic in architectural discourse, heritage preservation and nation building. ${ }^{18}$ The desire for authenticity in architecture today is a contributing factor in the expanding interest in heritage preservation. The rational, critical debate of Charles Taylor speaks has led to two important documents that connect authenticity to an external authenticating source: the Venice Charter and the Nara Document.

The Venice Charter of 1964 is an internationally recognized document stating that it is "our duty to hand [historic monuments] on in the full richness of their authenticity." ${ }^{19}$ The Venice Charter introduced the term authenticity in its preface and became a framework for recognizing authenticity in architecture. The document is a code of professional standards which sets forth principles of preservation and restoration of historic buildings based on the "test of authenticity in design, materials, workmanship, and setting." ${ }^{20}$ Thirty years later, the Nara Document on Authenticity of 1994 was created as a response to the challenge of defining authenticity based solely on the universal conditions listed in the Venice Charter. The previously stated "test of authenticity" was reformulated to include new parameters such as "form and design, materials and substance, use and function, traditions and techniques, location and setting, spirit and feeling, and other internal and external factors." ${ }^{21}$ 
If one accepts a definition of authenticity that can be broken down into individual components, then parts are subject to evaluation for the whole to be collectively deemed genuine. This kind of approach to authenticity in architecture has made it mainly a subjective debate. In order to define the value of a particular heritage site or structure, its relevant parameters and specificity must be critically and comparatively evaluated taking into account the diversity of heritage deemed sites and their interpretations. ${ }^{22}$ At the drafting of the Nara Document in Nara, Japan, the concept of progressive authenticities defined as the historical palimpsest that a property has acquired over time was established, as was the importance of flexibility. The Nara Document proposed a vision of authenticity as more intangible, relative, and culturally diverse..$^{24}$

Though the word authentic has no literal translation in certain languages, the Nara document recognizes that the concept itself exists in every culture. The concept of authentic approaches to historic sites must be inclusive of different traditions. ${ }^{25}$ The values which guide reconstruction of a damaged site should be culturally defined and maintenance and repair should consider traditional forms, methods, materials and suitable parameters (i.e. the new layer should not take away from the original structure).

The word integrity is often used in discussions on preservation and built heritage and refers to a state honesty. In the Nara document, authenticity refers to the reconstruction of a site through methods that respect the historic character of the original. Buildings and properties are said to retain their integrity over time if the character defining features are preserved which include decorative details, craftsmanship, massing, materials and finishes. ${ }^{27}$

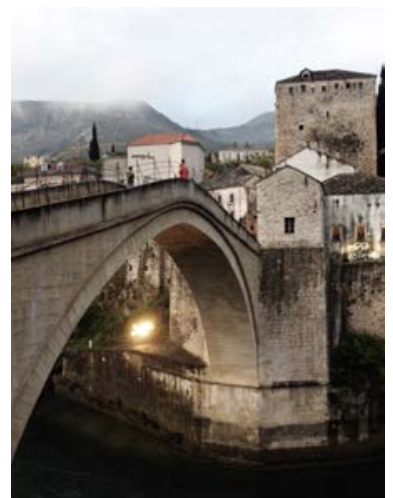

iMAGE 5. The Old Bridge in Mostar, Bosnia.

The reconstruction of the Old Bridge after its complete demolition in the civil war reflects a change in the international heritage field to place greater emphasis on intangible values. In the case of the Old Bridge, criterion (vi) of the Nara Document required a property to be "directly or tangibly associated with events or living traditions". ${ }^{23}$

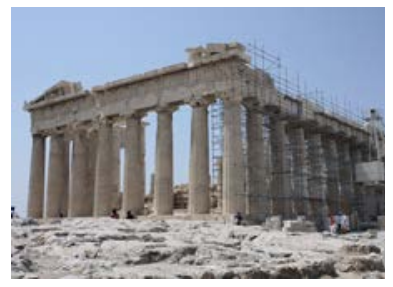

IMAGE 6 . The Parthenon on the Athenian Acropolis in Greece.

Anastylosis is a reconstruction technique where a damaged monument or building is restored using the maximum capacity of original architectural elements. Anastylosis is currently being applied to the ongoing restoration of the Parthenon. ${ }^{26}$ 


\section{4 | RE-APPROPRIATING MEMORY}

"One who cannot remember can hardly imagine because memory is the soil of the imagination. Memory is also the ground of self-identity; we are what we remember."

-Juhani Pallasmaa in Space, Place, Memory and Imagination, 2007

The city of Salonica serves as a contemporary example of the formation of a nation state identity through discourse of authenticity of its architectural fabric. ${ }^{28}$ Salonica, later renamed Thessaloniki, is a small provincial town in Greece which experienced rapid demographic and urban growth under the Ottoman administration between the $15^{\text {th }}$ and $19^{\text {th }}$ centuries. Its modernization at the beginning of the $20^{\text {th }}$ century was in large part due to the Millet system. ${ }^{29}$ However the Islamic nature of the Ottoman Empire characterized Salonica's urban landscape with elements of oriental architecture and occasional features borrowed from classical and western forms of architecture. Following the Balkan war of 1912 to rid the territory of Ottoman rule, Salonica fell under the Kingdom of Greece. The new administration chose to purge the city of all Ottoman heritage and non-Greek memory pertaining to its occupation, to highlight the city's

Greek past through its architecture.

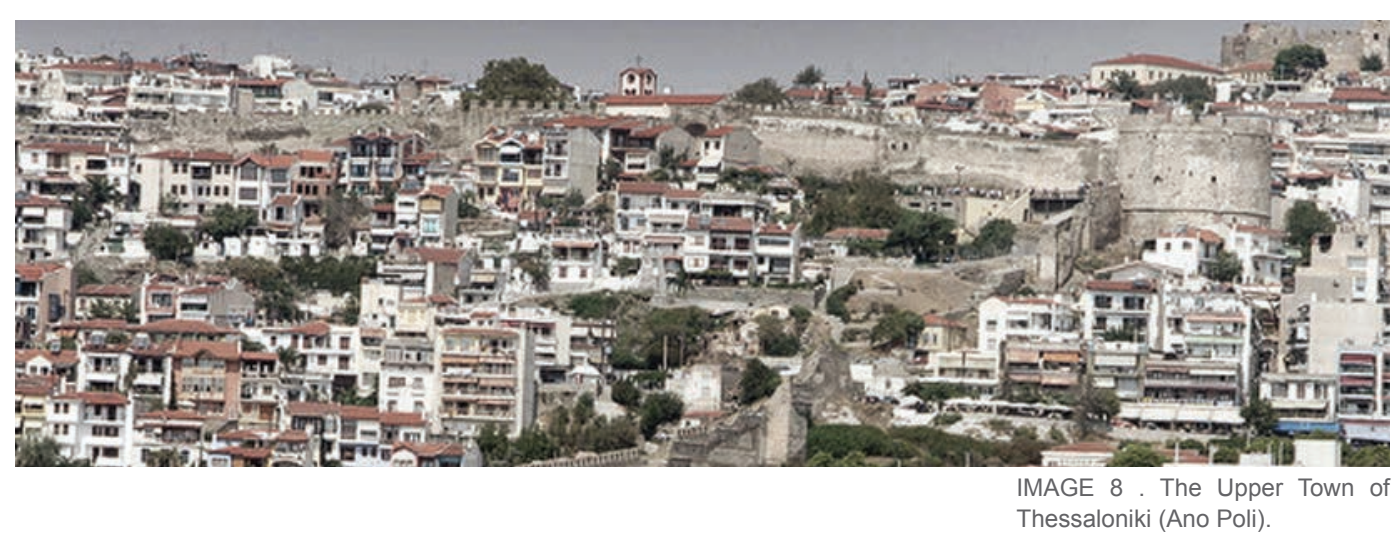


The Muslim population of Salonica was quickly declining during this time and events such as the big fire of 1917 that destroyed almost two thirds of the city as well as the Nazi occupation during WWII, would contribute to the greekification of the city and ethnic homogenization of its people. The reconstruction which occurred during the interwar decades shed the city of its Ottoman presence and resuscitated its former neo-Hellenic and Christian past. This involved demolishing buildings around the city's main monuments (such as the Rotunda and the Agora) that brought emphasis to these landmarks and formed public squares around them. ${ }^{29}$ These squares were decorated with statues of Greek heroes and the surrounding building facades were covered with Greek ornamental motifs. The existing ottoman city plan characterized by winding and narrow streets was reshaped into a rigid grid. By the mid20th century, Salonica had become a Greek town not only in ethnic demographic, but in urban form and fabric. A new identity had been imposed on Salonica.

Cities have a way of re-appropriating collective memories. ${ }^{30}$ In times of peace, emphasis shifts to the importance of architectural monuments as authentic reminders of the past. The last few decades in Salonica have seen a considerable spike in attention to heritage issues which has precipitated the restoration of a number of mosques, hammams and other remnants of the Ottoman period, particularly the old Turkish quarters of Ano Poli. Today Salonica is a UNESCO world heritage site with many of its Ottoman and Byzantine structures having been restored and readapted creating a new national identity.

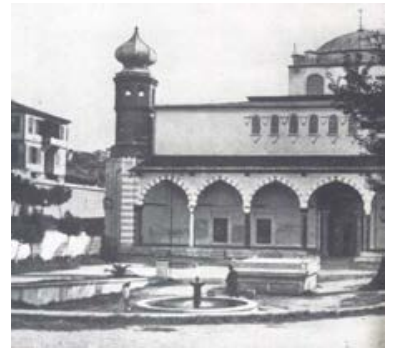

IMAGE 9 . The Hagia Sophia as a mosque in 1900. It was converted from a church in 1430 after the capture of Thessaloniki by the Ottoman Empire.

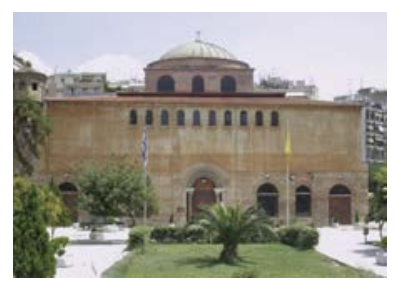

IMAGE 10 . The Hagia Sophia as a church upon the liberation of Thessaloniki in 1912. Much of has been stripped of its former oriental elements. Today it is one of several monuments in the city included as a World Heritage Site on the UNESCO list. 
Heritage preservation asserts a history that is unique and authentic to it, and places modern individuals on a trajectory of on-going progression rather than as simply a member of a static mass. ${ }^{31}$ In The Ethics of Authenticity, Charles Taylor attributes the exaggerated individualism and break from traditional values in modern society to the "disenchantment" of our world as "the dark side of the individual, which both flattens and narrows our lives, makes them poorer in meaning, and less concerned with others or society." ${ }^{32}$ Civic nationalism has led to the use of architectural preservation not only as a utilitarian means to conserve the physical form of a building, but rather as scaffolding to reveal the collective and cultural past of a nation that led to its present state. The act of preserving built urban heritage provides a physical narrative of a city's cultural development. 


\title{
ENDNOTES
}

\author{
1. Benjamin, Walter. "On Language as Such and on the Language of Man." \\ Walter Benjamin: Selected Writings 1 (1996): 62-74 p.63 \\ 2. Pallasmaa, Juhani. "Space, Place, Memory and Imagination: The Temporal \\ Dimension of Existential Space." Spatial Recall: Memory in \\ Architecture \\ and Landscape na, 2001. p. 17 \\ 3. ibid., p. 18 \\ 4. Benjamin, Walter. The work of art in the age of mechanical reproduction. \\ Penguin UK, 2008. p. 4 \\ 5. Gladwell, Malcolm. Blink: The power of thinking without thinking. Back Bay \\ Books, 2007. p. 6 \\ 6. ibid., p. 7 \\ 7. Richter, Gerhard. Walter Benjamin and the corpus of autobiography. Wayne \\ State University Press, 2002., p. 64 \\ 8. Benjamin, The work of art, $p$. \\ 9. ibid., \\ 10. ibid., \\ 11. Vannini, Phillip, and J. Patrick Williams, eds. Authenticity in culture, self, and \\ society. Ashgate Publishing, Ltd., 2009. p. 39 \\ 12. ibid., p. 21 \\ 13. Taylor, Charles. The Malaise of Modernity. House of Anansi, 1991. p. 27 \\ 14. Conway, Daniel W., and Peter S. Groff, eds. Nietzsche: On morality. Vol. 3. \\ Taylor \& Francis, 1998.. p. 323 \\ 15. Taylor, Charles. The Malaise of Modernity. House of Anansi, 1991. p. 29 \\ 16. ibid., 48 \\ 17. Taylor, Charles. Modern Social Imaginaries. Duke University Press, 2004. p. 83 \\ 18. Cameron, Christina. "From Warsaw to Mostar: the World heritage Committee \\ and Authenticity." APT Bulletin: Journal of Preservation Technology 39, \\ no. 2-3 (2008): p. 20
}

19. Charter, Venice. "International charter for the conservation and restoration of monuments and sites." In Second international congress of architects and technicians of historic monuments. 1964.

20. ibid.

21. Stovel, Herb. "Origins and Influence of the Nara document on authenticity."APT Bulletin (2008): 9-17.

22. Jerome, Pamela. "An introduction to authenticity in preservation." APT Bulletin39, no. 2/3 (2008): 3-7

23. Cameron, "From Warsaw to Mostar" p. 23.

24. ibid., p. 23

25. ibid., p. 24

26. Jerome, "An introduction to authenticity", p. 3

27. ibid., p. 6

28. Downes, Brant William. Constructing the modern Ottoman waterfront: Salonica and Beirut in the late nineteenth century. ProQuest, 2007. p. 17

29. ibid., p. 32

30. Trieb, Marc. "Remembering Ruins, Ruins Remembering." Spatial Recall: Memory in Architecture and Landscape. Routledge, 2013, p. 22

31. Rajagopalan, M. (2012). Preservation and Modernity: Competing Perspectives, Contested Histories and the Question of Authenticity. The SAGE Handbook of Architectural Theory, 308.

32. Taylor, Charles. The malaise of modernity. House of Anansi, 1991. p.5 


\section{Chapter 2: The Modern}

mod•ern

adjective

1.

of or relating to the present time or the recent past : happening, existing, or developing at a time near the present time

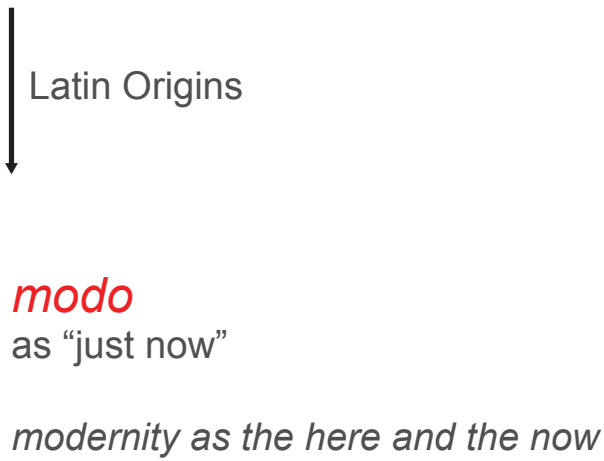




\subsection{DEFINING MODERN}

Architectural historian Hilde Heynen identifies three modes of "the modern"; the current, the new, and the transient. ${ }^{1}$ The root of the word comes from the Late Latin word modernus, derived from modo meaning 'just now or in a certain manner'. This is the first and oldest sense of the word, dating back to the middle ages. In Shakespeare, the word modern was used with a sense of "every-day, ordinary, and commonplace." The second sense of the term comes in the late $17^{\text {th }}$ century following a period of great social and cultural change in Europe. In this period, the term modern was used to denote the historical period following the middle ages. Modern as an adjective thus first emerged to refer to the present and current in contrast to the past which was regarded as ancient and old-fashioned. In general academic discourse, the period prior to modernity is characterized as agrarian and feudal, with public consciousness governed by religion. The understanding of modernity as the here and now is linked with the industrialization, capitalism, and progressive social thought of the $19^{\text {th }}$ and $20^{\text {th }}$ centuries. ${ }^{3}$

This etymology of the word modern as the here and the now reflects the problematic chronology of modernization today; it is notion by which to define an everchanging present. Since the Enlightenment, modernity has been related to the notion of reason. ${ }^{6}$ "Nothing is permanent; reason becomes identified with change and otherness. We are ruled not by identity, [...] but by otherness and contradiction, the dizzying manifestations of criticism. In the past the goal of criticism was truth; in the modern age truth is criticism. Not an eternal truth, but the truth of change."7

\footnotetext{
$\bullet$ in॰dus•try: noun

1. economic activity concerned with the processing of raw materials and manufacture of goods in factories 2. hard work

(Oxford: Canadian Dictionary)

The word industry itself is derived from the late 15th century French word industrie, meaning "activity or aptitude", or directly from the Latin word industria, meaning "diligence, activity, zeal". ${ }^{4}$ As cities experienced massive urban growth and expansion, the urban form of industrial capitalism became the standard of modernization, and the word industry took on a new meaning referring now to a new sector of the economy. ${ }^{5}$
} 


\subsection{MOdeRnIty AS the FleEting}

"Modernity is the transitory, the fugitive, the contingent,
which makes up one half of art, the other being the
eternal and the immutable. This transitory fugitive
element, which is constantly changing, must not be
despised or neglected."

- Charles Baudelaire in The Painter of Modern Life, 1864

Modernity has been marked by a questioning and rejection of the past, leading to changes driven by progress towards the future. It is also a frame of mind that embraces industrialization, urbanization and the rise of bureaucracy, nationalization and capitalism. In this way, modernism can be seen as a movement which is both an objective one, linked to socioeconomic process, and a subjective one, linked to theoretical reflections and analysis.

The third understanding of the word modern evolved during the $19^{\text {th }}$ century as a connotation of the fleeting and transitory, and of the impermanent. This modern differentiated the present from the past and propelled us into the future. Modernity became increasingly visible in the changing urban environment driven by great political and economic shifts. A new power of the industrial order has reinvented social relationships with the physical environment and overturned earlier ways of thought. This urban-industrial rupture has created the modern city which became more than an intellectual notion or concept. ${ }^{8}$

"The only thing that can last is the essence, otherwise it's transitory, it's fashion".

- I.M. Pei in First Person Singular, directed by Peter Rosen, 1997 
In his 1859 essay The Painter of Modern Life, Charles Baudelaire described modernity as "the transient, the fugitive, [and] the contingent". The painter of modern life an illustrator and quick sketch artist who spent his days depicting fast-paced scenes of modern life but more importantly an outsider to the emerging bourgeois society of Paris much like Baudelaire. ${ }^{9}$ Modern urban life in 19th century Paris was defined by the concept of constant change and an increasing rise of individualism. In this long essay Baudelaire describes the social conditions in Paris during the urban transformations of Haussmann. Haussmann's 'renovation' of Paris was undertaken to clear away "crowed and unhealthy" medieval neighbourhoods and to improve the quality of life in the capital. The identification of metropolitan modernity as a quality of life governed by the "ephemeral, contingent newness of the present" was associated with the destruction of the past. ${ }^{10}$

Baudelaire is a key figure in discourse on modernity and his work was interpreted and analyzed by many subsequent thinkers. Benjamin translated some of Baudelaire's essays and echoed Baudelaire in own literary work. More recently, Marshall Berman reaffirms and elaborates on the overall vision of modernity constructed by Baudelaire: "these first modernists may turn out to understand us - the modernization and modernism that constitute our lives - better than we understand ourselves". ${ }^{12}$

Baudelaire's presentation of modernity as the fleeting implies the impermanent character of the present. This notion is presented and elaborated in what Benjamin calls The Destructive Character. which will play a key role in this thesis in developing a modern architectural intervention to an component of built heritage.

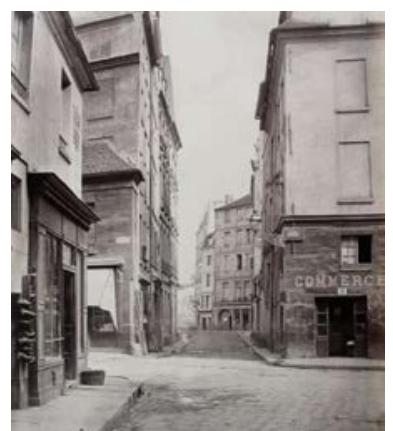

IMAGE 11 . Rue des Grans-Degres in Paris, $1865-69$

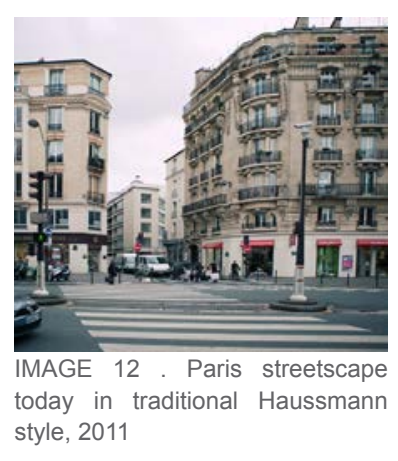

- Baudelaire expressed criticism for Haussmann's rebuilding of Paris through his poem The Swan: ${ }^{11}$

"Old Paris is gone (no human heart changes half so fast as a city's face)... There used to be a poultry market here, and one cold morning... I saw a swan that had broken out of its cage, webbed feet clumsy on the cobblestones, white feathers dragging through uneven ruts and obstinately pecking at the drains..

Paris changes ... but in sadness like mine nothing stirs-new buildings, old neighbourhoods turn to allegory,
and memories weigh more than stone." 
'There is a mode of vital experience-experience of space and time, of the self and others, of life's possibilities and perils-that is shared by men and women all over the world today. I will call this body of experience "modernity". To be modern is to find ourselves in an environment that promises us adventure, power, joy, growth, transformation of ourselves and the world-and, at the same time, that threatens to destroy everything we have, everything we know, everything we are. Modern environments and experiences cut across all boundaries of geography and ethnicity, of class and nationality, of religion and ideology: in this sense, modernity can be said to unite all mankind. But it is a paradoxical unity, a unity of disunity: it pours us all into a maelstrom of perpetual disintegration and renewal, of struggle and contradiction, of ambiguity and anguish. To be modern is to be part of a universe in which, as Marx said, all that is solid melts into air' 


\section{3 | The Destructive ChaRACter}

The perpetually evolving nature of modernity establishes a rapidly shifting landscape as contemporary mindsets are recognized and subsequently discredited by new generations of theorists. To be a modernist is to "make oneself somehow at home in the maelstrom, to make its rhythms one's own, to move within its currents in search of the forms of reality of beauty, of freedom, of justice, that its fervid and perilous flow allows." ${ }^{13}$

Marshall Berman's All That Is Solid Melts Into Air: The Experience of Modernity calls for a re-examination of modernity in the $20^{\text {th }}$ century. Berman saw the experience of modernity as one of tension and paradox in modern life; the tension between modernity as a sporadic and unregulated movement and modernity as a process of rational critique whose consequence is the regulation of movement. This paradox in modernity which Berman establishes can be seen as the tradition of the modern, which in turn leads us to the tragedy of development. The concept of modernity is personified in Goethe's Faust, a character whose "desire for development"14 leads him to bargain with his soul. The story of Faust represents the similarity between the ideal of self-development and the existing social movement toward economic development. Goethe's character is revelled as a hero for his liberation of repressed human energies - intellectual, moral, economic and social, but in doing so turns to the infernal arts of industrialisation and technology. This in turn initiates the self's inevitable destruction, which Berman argues is an integral part of self-development and hence of modernity. "In [Faust's] new work, he will work out some of the most creative and some of the most destructive potentialities

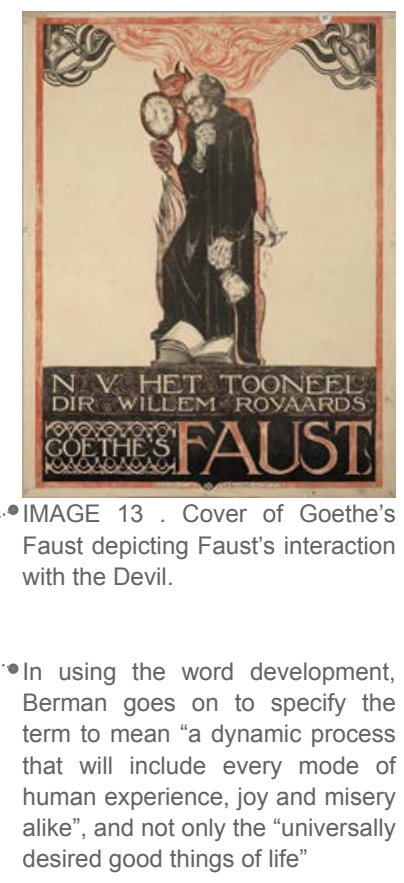


of modern life: he will be the consummate wrecker and creator, the dark and deeply ambiguous figure that our age has come to call the developer." ${ }^{15}$ Berman argues that in the $20^{\text {th }}$ century, "faustian development has come into its own"16 through the success of the capitalist world.

Benjamin's concern stems from the consequences of modernization on the personal and spatial qualities of the daily life. The effect of modernity on self-development requires a sensibility and consciousness in order to benefit from its effects and become an enriched notion of selfawareness.

In his short essay entitled The Destructive Character, Benjamin presents destruction as crucial to rejuvenation of self and in turn to the creation of new, reanimated forms of life. To be modern means accepting destruction as a positive. Modernity embraces this method of cleansing as essential to the intellectual, technological and overall advancement of human progress. "The destructive character is young and cheerful. For destroying rejuvenates, because it clears out of the way the traces of our own age; it cheers because every clearing away means, to the destroyer, a complete reduction, indeed eradication, of his own condition." ${ }^{17}$ Benjamin describes the modern destructive character as Apollonian, meaning that it is based on reason and logical thinking as opposed to the Dionysian character we traditionally attribute to destruction. Returning to Benjamin's essay on the work of art, we can compare this notion of the destructive character to modes of technical reproduction. Photography is seen as the antithesis to the aura of an object, yet through the elimination of aura we are introduced to the possibility of a dynamic new knowledge: the optical unconscious. ${ }^{18}$ The destructive element that guarantees the authenticity of dialectical thought is this same element that guarantees the temporality of the present.

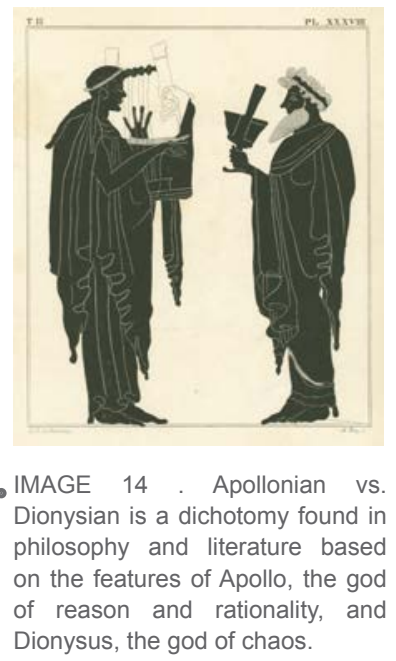

- "With the close-up, space expands; with slow motion, movement is extended. The enlargement of a snapshot does not simply render more precise what in any case was visible, though unclear: it reveals entirely new structural formations of the subject" 


\section{ENDNOTES}

1. Heynen, Hilde. Architecture and modernity: a critique. MIT press, 2000., p. 20

2. Lukacs, John. Democracy and populism: Fear \& hatred. Yale University Press, 2005. p. 1921

3. Short, John Rennie. Globalization, modernity and the city. Routledge, 2013. p. 53

4. ibid., p. 53

5. ibid., p. 54

6. Heynen, Hilde. Architecture and modernity: a critique. MIT press, 2000., p. 21

7. Paz, Children of the Mire, p. 26

8. Heynen, Architecture and modernity, p. 54

9. Hvattum, Mari, and Christian Hermansen. Tracing modernity: manifestations of the modern in architecture and the city. Routledge, 2004. p. 7

10. ibid., p. 8

11. Leakey, Felix William. Baudelaire: Les fleurs du mal. Cambridge University Press, 1992. p. 85

12. Berman, Marshall. All that is solid melts into air: The experience of modernity.

13. ibid., p. 346

14. ibid., p. 39

15. ibid., p. 63

16. ibid., p. 74

17. Benjamin, Walter. "The destructive character." Reflections: Essays, Aphorisms, Autobiographical Writings 301 (1978).

18. Benjamin, Walter. The work of art in the age of mechanical reproduction.

Penguin UK, 2008 
Chapter 3: Situating the Chapel

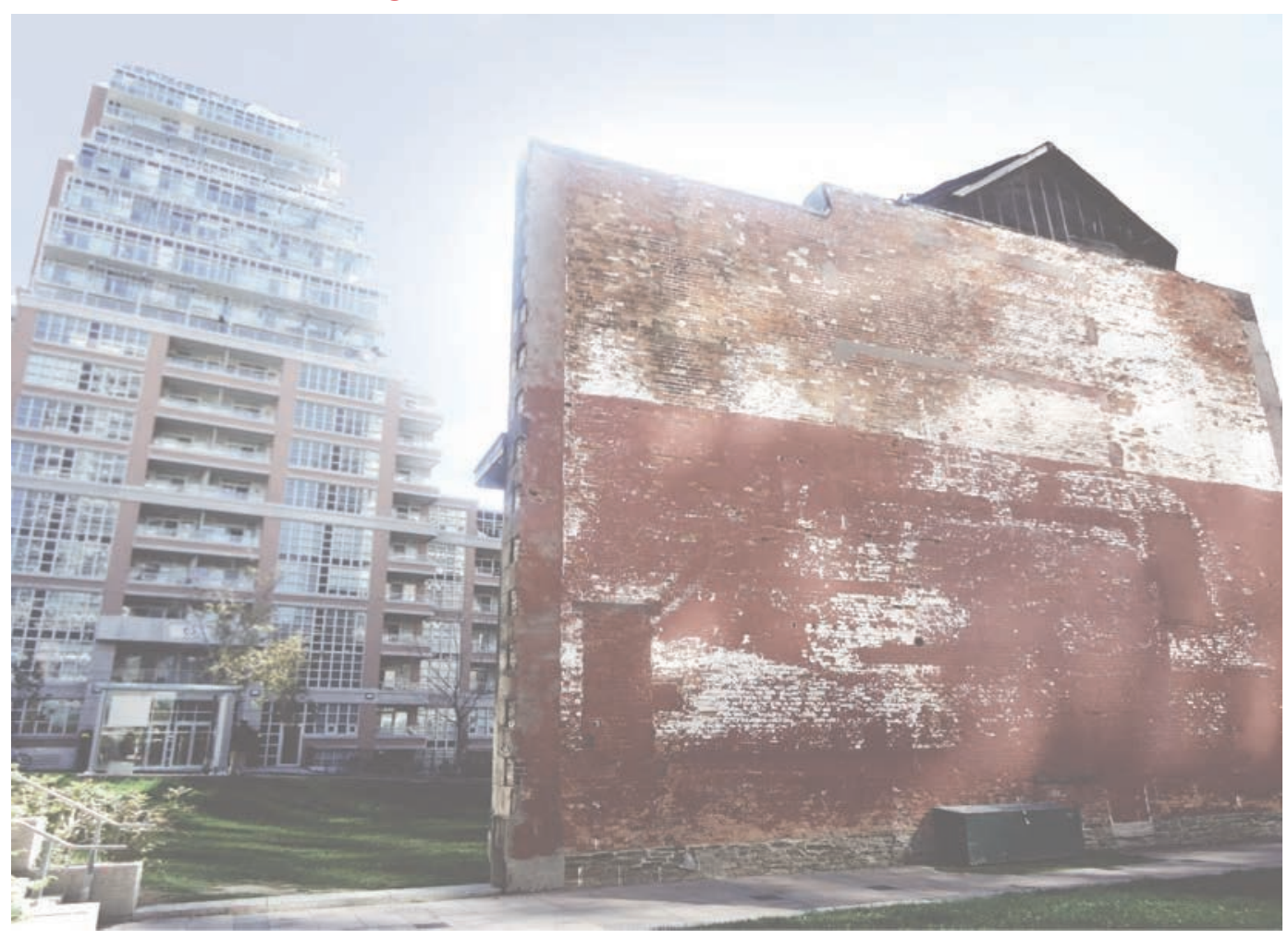


In the previous chapter, the notion of the destructive and fleeting character of modernity was elaborated and embraced as a constructive method of progress. However if one were to blindly follow the modernist ideology that all that is solid melts into air, what is to stop the complete demolition of a city's built heritage for the production of more modern edifices? The Prison Chapel was built in 1877, a few decades prior to the peak of industrialization in Toronto. If this chapel is a part of modernization of Toronto, naturally its process of death and rebirth should come with ease.

However while many modernist theories may center on the cycle of destruction and rebirth, modernization as a social development is partially characterized by an ever-expanding self-consciousness. It is likely for heritage preservationists to advocate against the destruction of built heritage as much as it is for modernists to embrace contemporary ideas. 
The following chapter will introduce the site for the design intervention and describe why Toronto's Liberty Village is an appropriate location for an architectural project that investigates the concept of the veil of modernity. This concept is driven by combining opposing notions of preserving authenticity in built heritage and the destructive cycle of modernity. Rather than placing our built heritage as the starting point for the cycle of modernisation, this intervention will propose a project where modernity becomes part of the life of the building. The subsequent interventions will be able to be erased as naturally as they are introduced, but the progressive authenticities of the building will now include these interventions. Thus the cycle of modernity and authenticity are able to coexist on a site: modernity becomes part of the cycle of destruction and rebirth of the Toronto Central Prison Chapel, rather than vice versa. This project will engage a site in Toronto that embodies this paradox. 


\subsection{TORONTO INDUSTRIAL DEVELOPMENT AND URBAN GROWTH}

Toronto's urban growth started in 1787, with the surrender by the Mississaugas of Port Credit First Nations of $1000 \mathrm{~km}^{2}$ of land to the British Crown. The site for Toronto (then known as York) was chosen as the capital of the new province of Upper Canada and was built within a large protected bay formed by the Toronto Islands. The following century marked Toronto as a major destination for immigrants to Canada growing the population from 9,000 in 1800 to 65,000 in 1860 . Early settlement occured at the eastern end in what is today the Corktown-St. Lawrence area. ${ }^{1}$

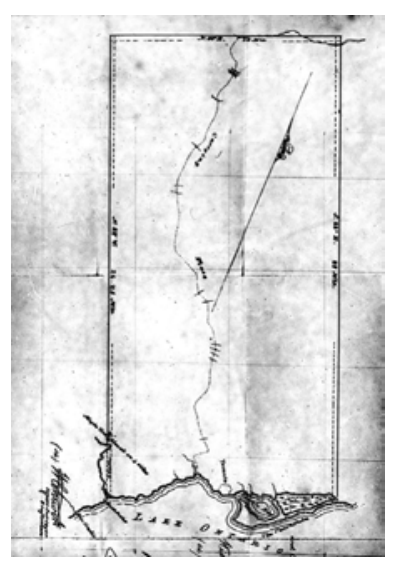

IMAGE 15. Map of the 1787 Toronto Purchase.

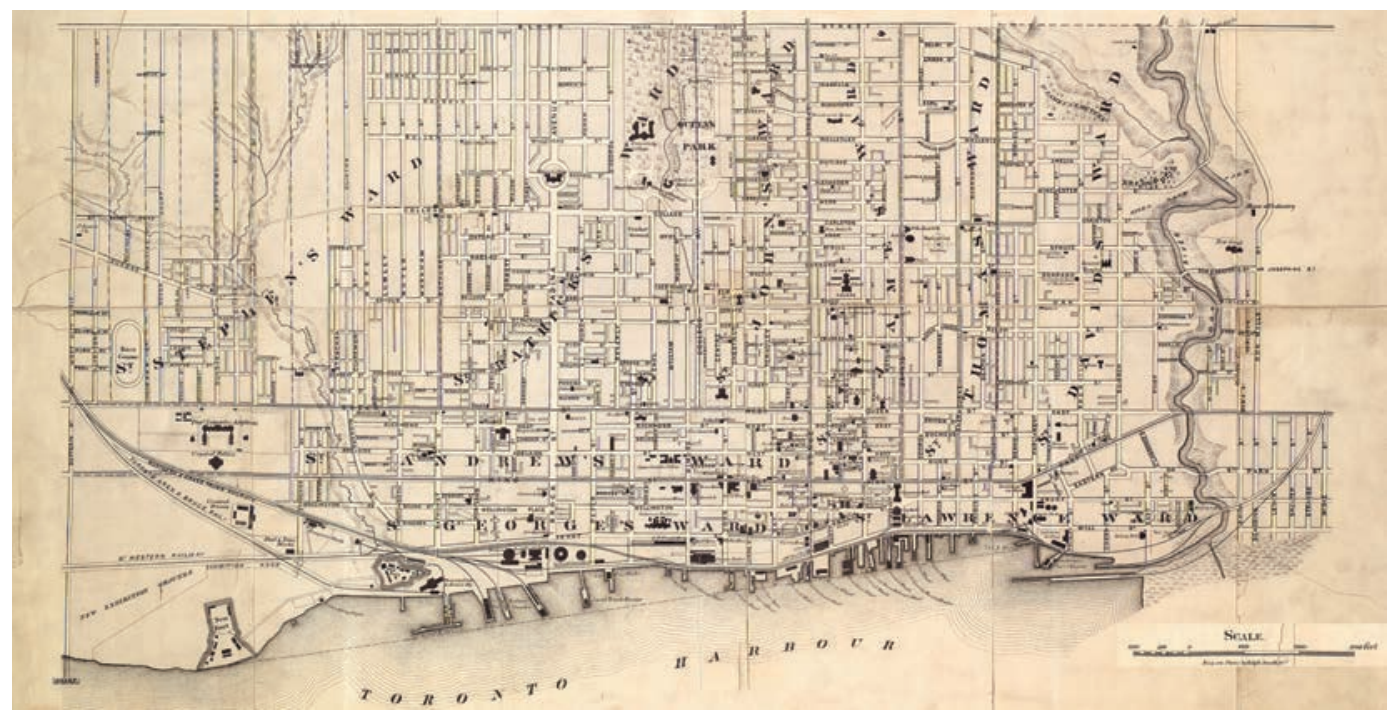

IMAGE 16. Map of Toronto in 1872 showing Toronto Harbour between Dufferin Street and Don Mills Road up to Bloor Street in the North. 
The Toronto harbor was gradually transformed into an industrial zone with long-distance railway lines and port facilities linking Toronto to the Upper Great Lakes. The arrival of the Grand Trunk Railway and the Northern Railway of Canada coupled with Toronto's growing influx of immigrants saw exponential growth of industrialization in Toronto in the 1800s. Due to its location on Lake Ontario, Toronto became a major gateway to interior Canada and the US, its manufacturing sector being the major source of employment for its residents at the time. The industrial port lands themselves were of such importance that the delineation of the old shoreline was moved by filling in the lakefront southwards, in some areas as much as 900 meters. Factories were established close to the railway and other major transportation routes and many adjacent rural areas along these routes were converted into industrial sectors. This trend continued well into the 20th century, when factories were expanded and adapted for war efforts and the city limits grew further out. Following the Second World War, Toronto's population had reached one million and in just 20 years the population would double to 2 million. $^{2}$

The postwar boom brought forth a rapid period of large-scale suburbanization, aided in large part by the growth of the automobile industry, the development of railways and highway corridors and the expansion of the Toronto Transit Commission (TTC). Suburbs allowed for working people to live away from city life, and consequently for industries to transfer their facilities to these areas which held lower land costs and room for future expansion. By the 1980s, Toronto surpassed Montreal and became Canada's largest primary economic centre, its downtown district slowly becoming a financial hub with the expansion of the national market. ${ }^{3}$ Companies which
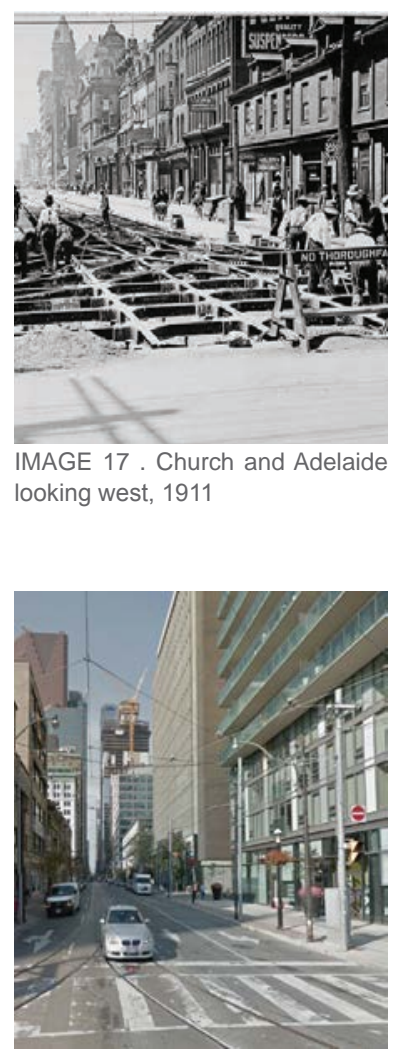

IMAGE 18 . Church and Adelaide looking west, 2014 
had relocated their operations to the suburbs left factories and warehouses in the city vacant and entire industrial districts became opportunities for change. Although some developers have chosen to take on the tabula rasa approach to dealing with derelict industrial sites, as was the case with most of Toronto's downtown core, others have fortunately preferred to preserve and readapt these sites to contemporary uses. This approach has created a patchwork of architecture in Toronto and contributed to its unique urban fabric.

During the industrial revolution a belt of industrial structures expanded east and west along the Toronto harbour. Looking at the city of Toronto today, few of these areas retain traces of that industrial heritage yet some have been preserved, converted, or are awaiting redevelopment plan such as the Port Lands District. In the east end, the Distillery District is a national heritage site which has adapted the massive Gooderham \& Worts Distillery into a thriving entertainment precinct and just north of this district is Corktown, a residential area which contains many vacant industrial buildings. Industrial buildings are often unoccupied due to environmental contamination and complex laws pertaining to their reuse. A similar condition is seen in the west end where areas in Brockton Village, Liberty Village, Weston and Junction neighbourhoods retain an industrial presence through remaining factories and rail yards. ${ }^{4}$

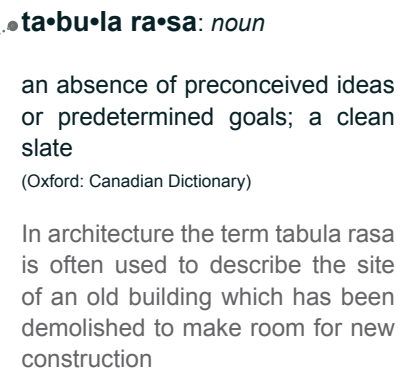

In architecture the term tabula rasa is often used to describe the site of an old building which has been demolished to make room for new construction

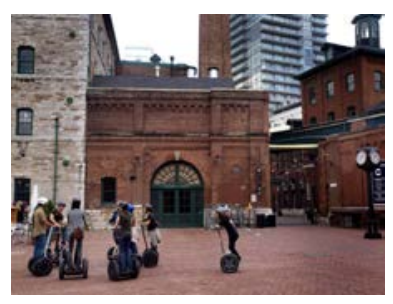

-IMAGE 19. Courtyard in Toronto's Distillery District. Part of its success as a redevelopment is due to its leasing policy. Distillery District owners do not lease any of their spaces to chains or franchises, choosing instead to occupy the buildings with boutiques, galleries, cafes, restaurants and the Mill Street Brewery. 


\section{3 | LIBERTY VILLAGE}

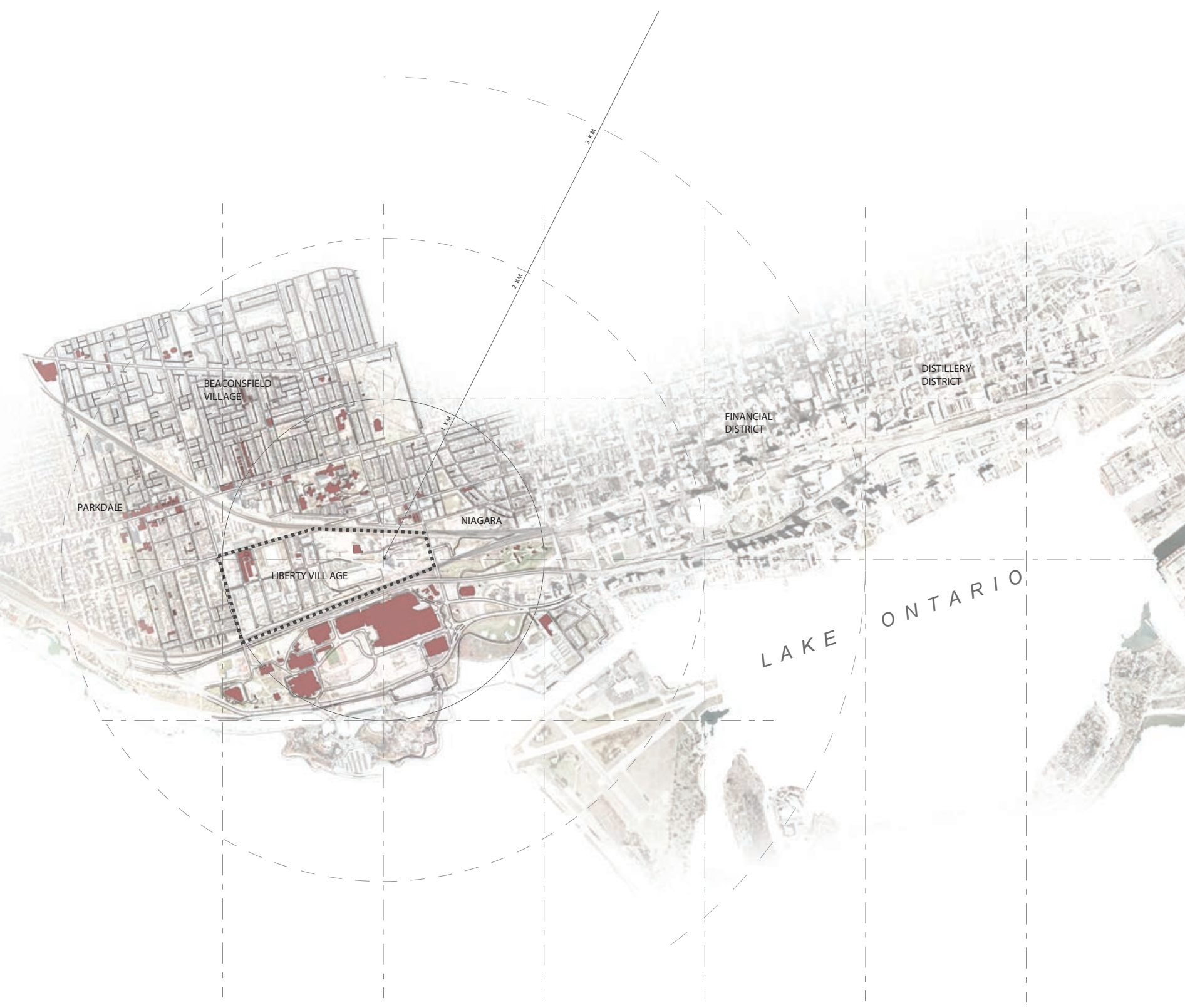


Before the advent of the railway in the 1850s, the area of Liberty Village served as a military fortification in Garrison Commons, one of Toronto's oldest settlements. Due to its location near the Toronto harbour, the Great Western Railway and the Toronto, Grey and Bruce Railway, the area was seen as an industrial hub rather than its intended use as a residential district. New warehouses and factories were built as well as the (now demolished) Toronto Central Prison that opened in 1873 and the Andrew Mercer Reformatory for Women that opened in 1878. The name Liberty Village comes from its main Liberty Street, so called because it "was the street upon which reformed prisoners set foot when they'd served their time."

During its time as the epicentre of Toronto's manufacturing industry, the John Inglis and Company and Massey-Harris (later Massey Ferguson) were the most

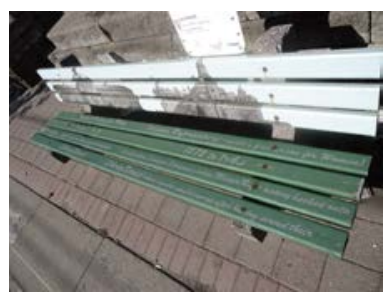

-IMAGE 20. "BENCHmark" is a unique art initiative by Liberty Village that converts old wood park benches into public art pieces. These benches celebrate the industrial past of the neighbourhood by utilizing its present creative potential. $^{7}$

This particular bench depicts the Toronto Central Prison for Men and the Mercer Reformatory for Women.

prominent and largest to have manufacturing factories in Liberty Village. Other companies include Irwin Toy, Canada Metal, Simmons Bedding and Sunbeam (later Canadian General Electric). Factories in Liberty Village were booming well into the 20th century. Some produced armaments and weapons for war efforts in 1940 and adapted to consumer products after the war. ${ }^{6}$ 


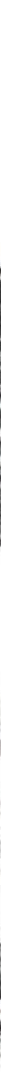


A few decades later, suburbanization, rising land costs and a shift from rail to road shipping meant the end of Liberty Village's industrial stronghold. By 1991, the Toronto Carpet Manufacturing plant had shut down, as had the Inglis plant and Massey-Harris factories. The latter two were demolished and many other factories closed as the site became home to a small population of artists drawn by low rents and the distinctiveness and eccentricity of the area. Gregory Green, film maker and local resident long before the gentrification of Liberty Village discusses what made the area unique for artists such as himself:
Artscape is a not-for-profit organization that creates spaces for artists in communities through collective housing with affordable rent. In 1991, Artscape opened its second location in Toronto in Liberty Village which provided 48 affordable artist studio spaces and played an important role in transforming the area into one of Canada's most important clusters of creative sector employment. - The area's makeover was promoted as an "artsy loft district" and "bohemian enclave", and with its desirable proximity to downtown it became the target of an influx of large-scale developers. In November of 2012, Artscape was forced to close its doors due to the rising cost of land value in Liberty Village. $^{8}$

"It was a beautiful area, there were actually meadows [former Inglis lands] you could walk through... you could wander through and see the old factories; you could climb into the old factories. It was beautiful. There was something very special about it. It lends a certain magic to a city to have abandoned spaces and you know those were natural magnets for artists and people who wanted to find their communities and their living spaces kind of in their own terms that is the people the neighbourhood used to attract."

The transition from an affordable artist's enclave to the trendy highrise condominium neighbourhood we know today started following municipal deregulation of zoning by-laws of the area in $1994 .{ }^{10}$ These changes attracted developers and real estate opportunists to the area and in turn evicted small businesses and low-income tenants to facilitate the conversion of these promising industrial buildings for residential and commercial purposes.

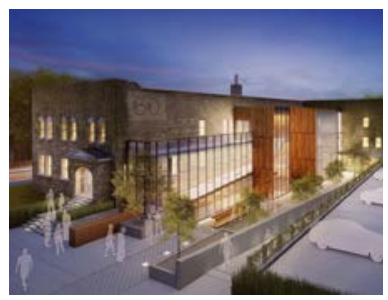

IMAGE 21 . Rendering showing proposed adaptive reuse of 60 Atlantic Avenue, former site of Artscape Liberty Village. 


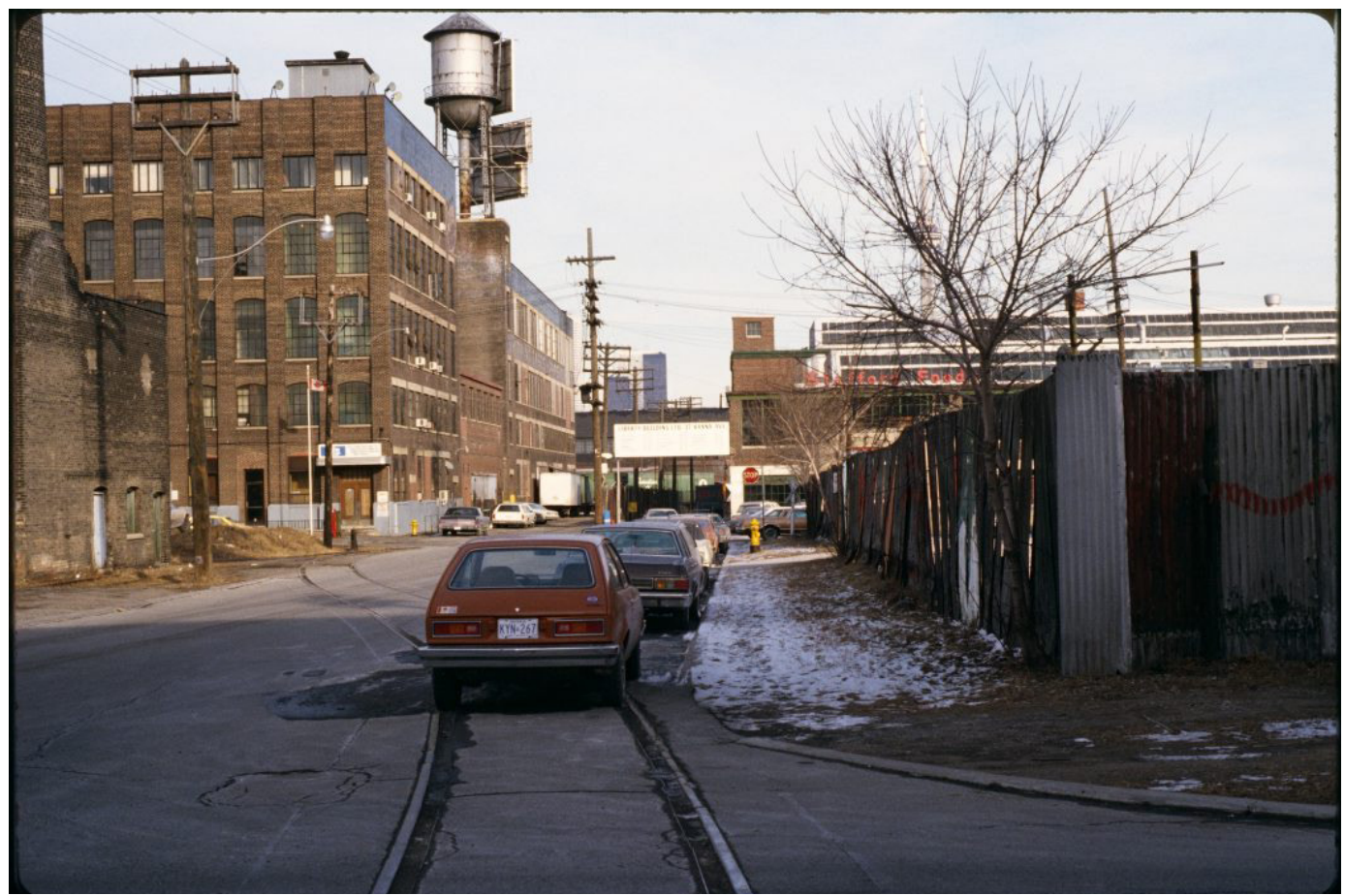

IMAGE 22 . Liberty Village,1970s

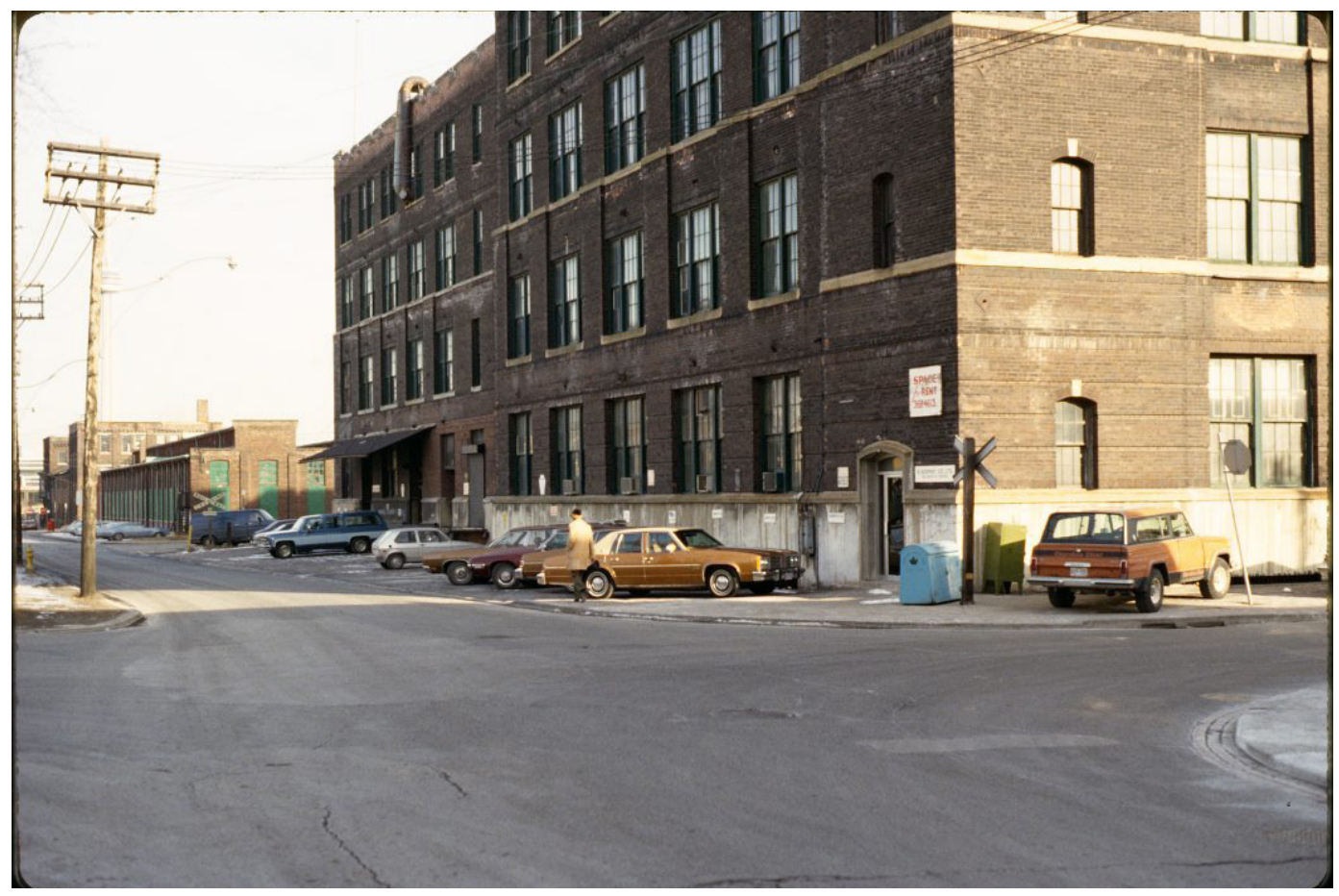

IMAGE 23 . Liberty Village, 1970s 


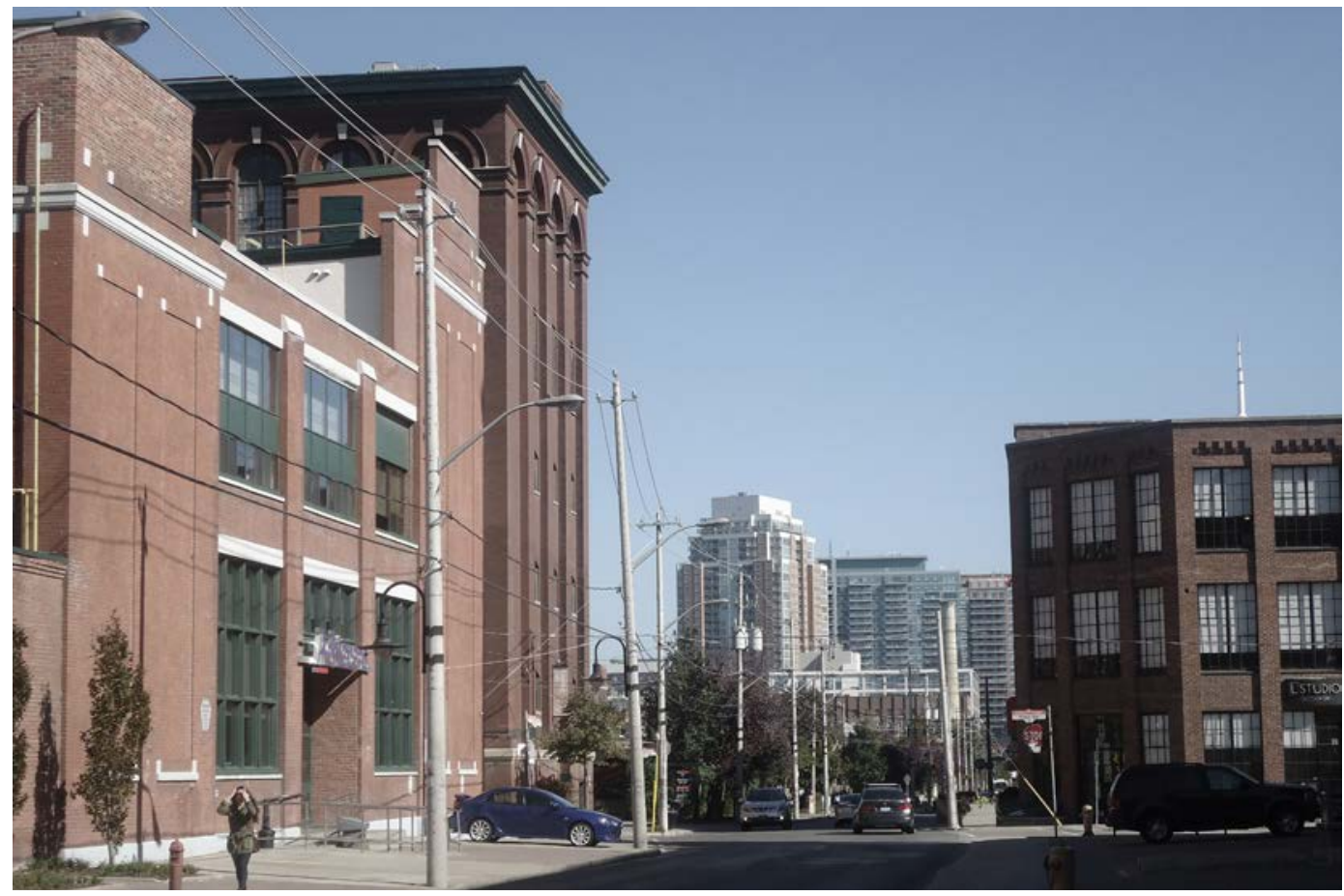

IMAGE 24 . Looking east Liberty Street and Dufferin Avenue, 2014

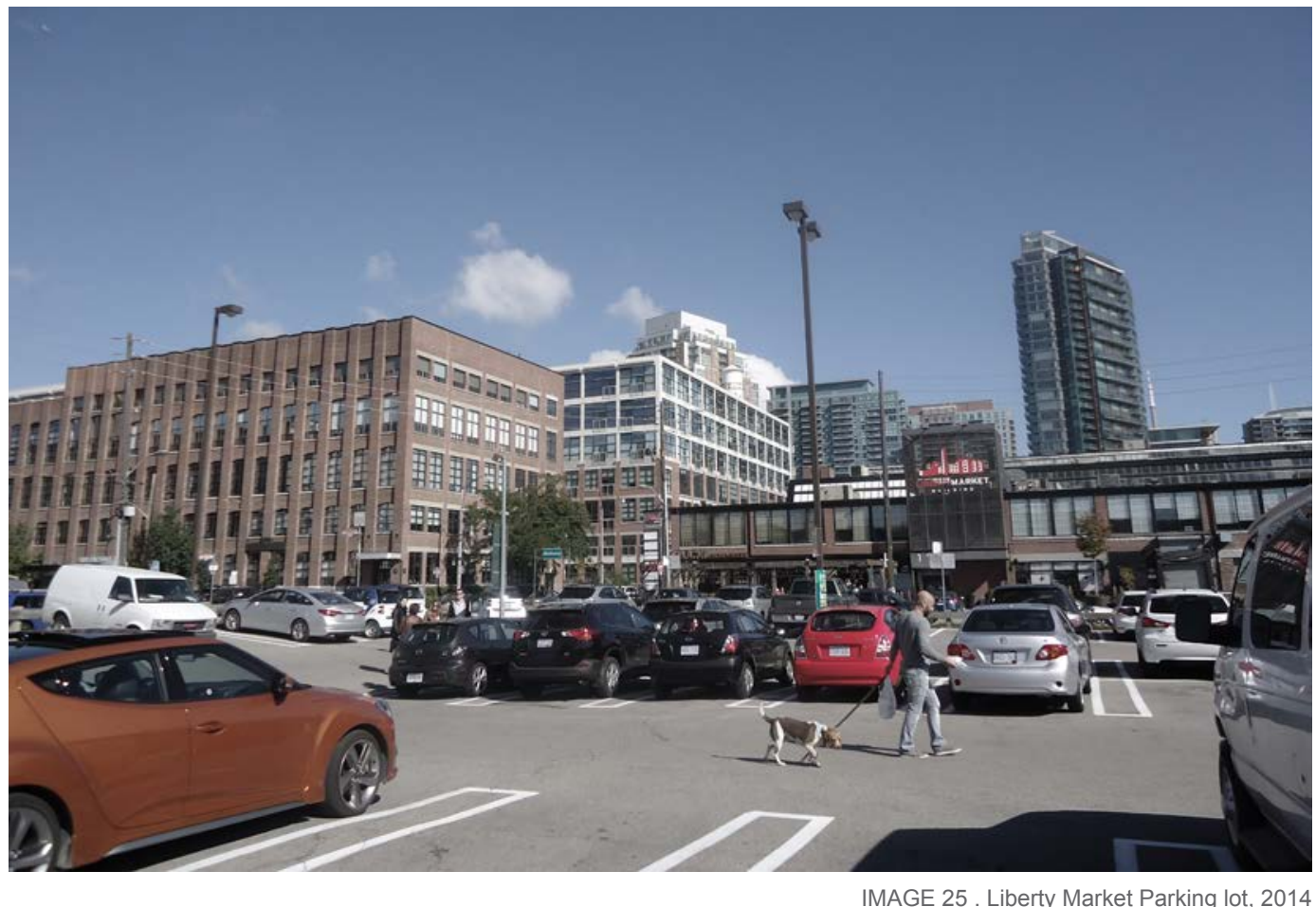


In 1994, Liberty Village was being described as "Toronto's west-end warehouse district"11 but by 2012 much of this industrial character has been overtaken by large condominium developments. Canadian magazine Toronto Life has described Liberty Village as a neighbourhood which has "morphed from an industrial dead zone into an enclave of concrete, glass and brick in just a few years". ${ }^{13}$

However the gentrification of Liberty Village has occurred in a different way and at a different rate in the east end than it has in the west; these two districts are separated by Hanna Street. To some, Liberty Village in the $21^{\text {st }}$ century is known for its successful art and design studios and its growing number of media and IT companies. It holds over 500 businesses and 7,000 employees in information technology, arts, design, entertainment and media. ${ }^{14}$ These occupations are focused largely in the west end of Liberty Village which holds all of the districts mixed-use spaces in former industrial buildings. The interesting architectural character which many attribute to Liberty Village is found almost exclusively on this side.

The east end, however, has effectively demolished all of its previously existing buildings but two - the Toronto Central Prison Chapel and the A.R. Williams Machinery Building. The arrival of large-scale residential developers in the east end has brought forth a drastic rise in density and stripped almost all of the historic identity of the neighborhood's east end.
The over-development of Liberty Village has given rise to some negative reviews in recent years, such as this statement by Christopher Hume of the Toronto Star: ${ }^{12}$

- "Despite its successes, Liberty Village illustrates everything that's wrong with planning in Toronto.

[...]

Although some of the individual projects are excellent, the city has failed to ensure that they add up to a genuine neighbourhood. Wandering the streets of Liberty Village, one is saddened to encounter one huge parking lot after another; they suck the life out of the precinct and give that hardscrabble look you might expect in an industrial park."

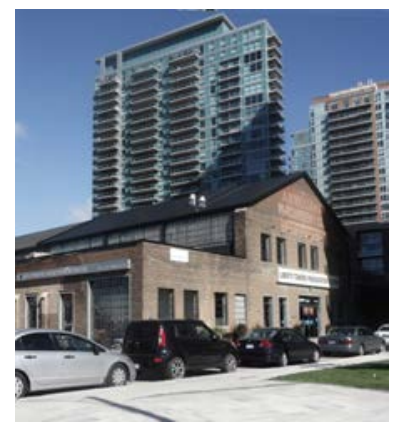

-IMAGE 26 . A.R. Williams Machinery building built in 1929 as part of the prison paint shop. It is currently being used as a condo presentation center. ${ }^{15}$ Current urban design guidelines propose the reuse of the south portion of the building to be adaptively reused in a condo development. 


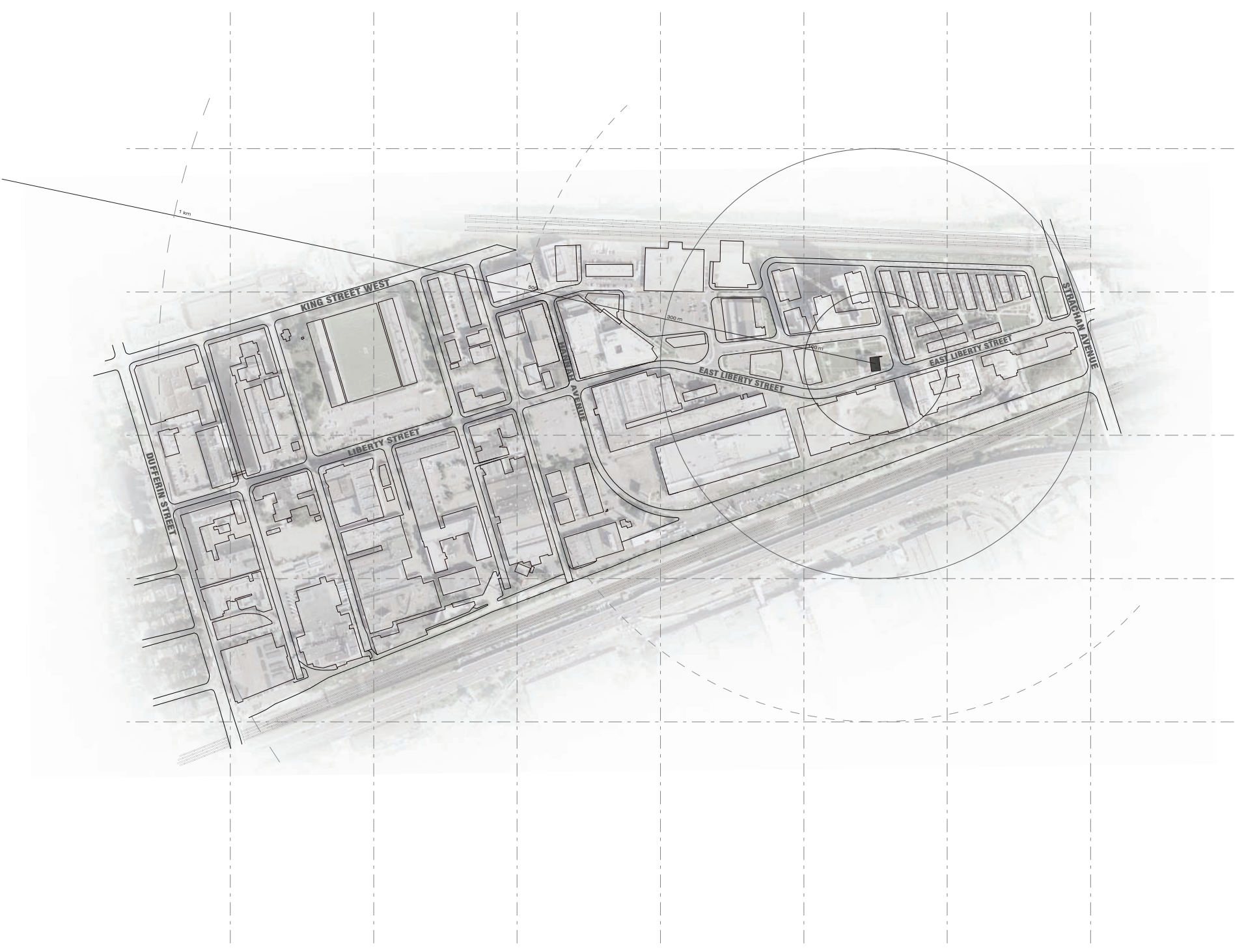




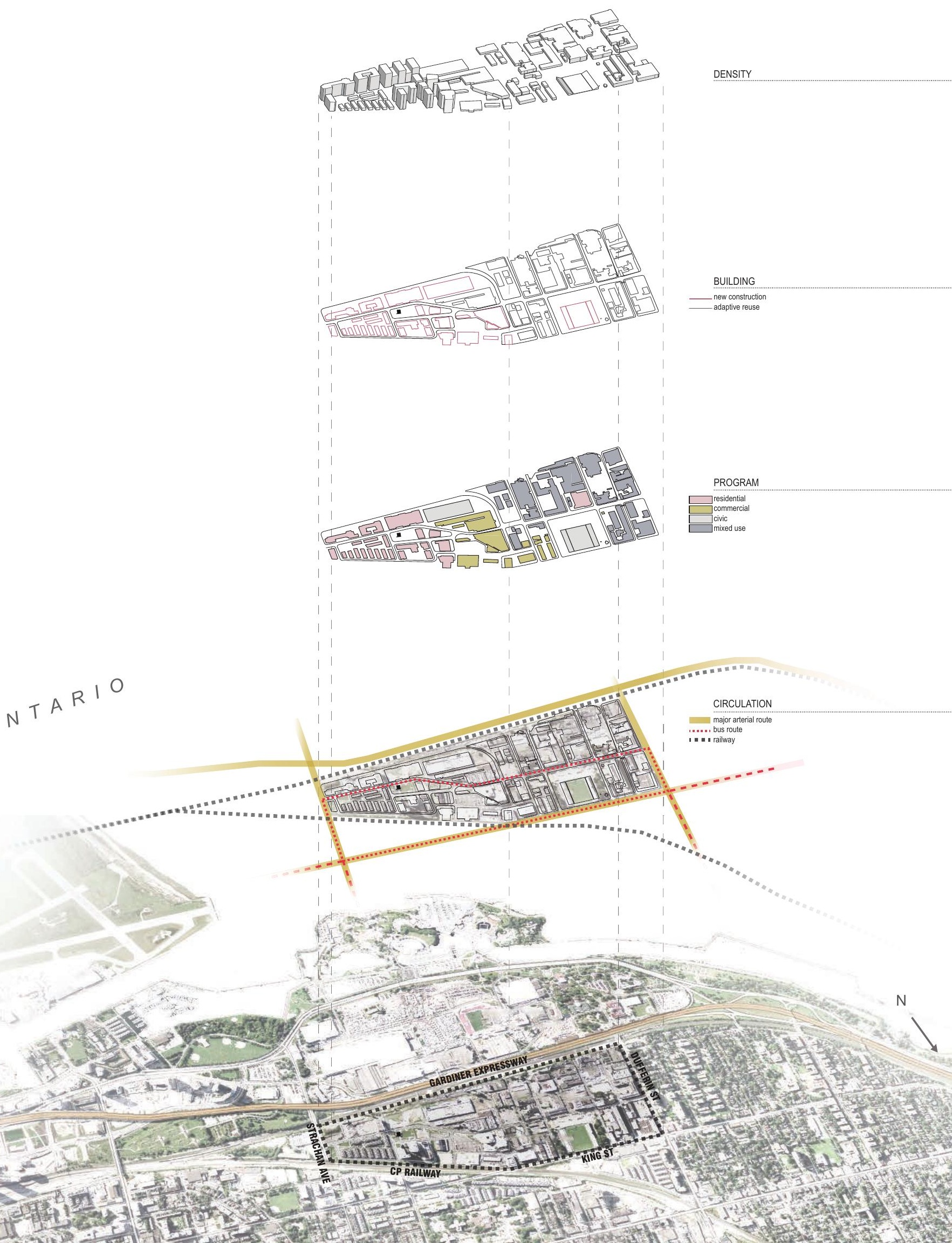



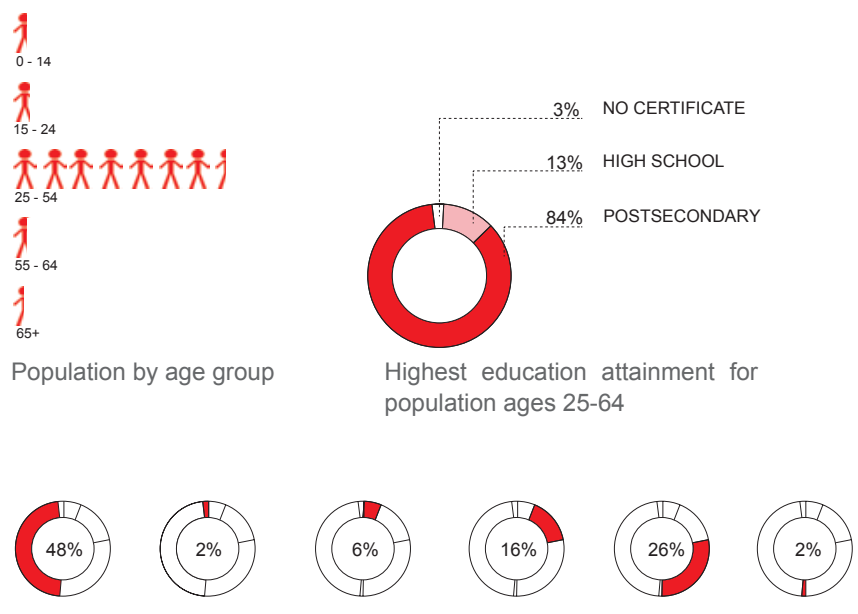

SINGLE

WIDOWEDD

IVORCEDC

OMMON LAW

MARRIED

SEPARATED

Legal marital status
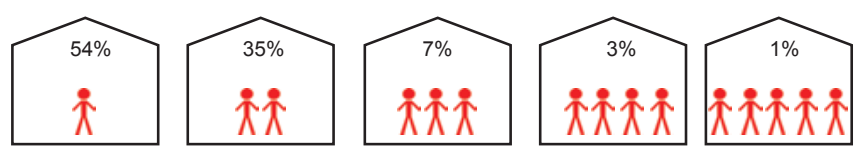

Private households by size

The Toronto Central Prison Chapel is located in the east end of Liberty Village, which by ward boundaries belongs to the Niagara district. ${ }^{16}$ The red circle indicates the location of the Toronto Central Prison Chapel. Since the boundaries of the ward of Niagara do not include the whole of Liberty Village, the statistics of the 2011 census may be somewhat different from the actual Liberty Village demographics. However the overall image presented is

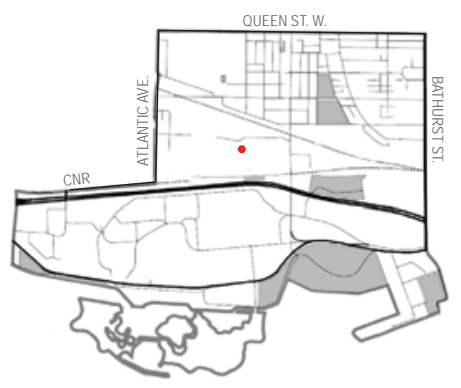
fairly accurate in terms of housing, education and age attributes of the area. 
Liberty Village, particularly the east end, is home to a large population of young, well-educated urban professionals. These residents have been dubbed the urban digerati population of Toronto. The presence of this growing population reflects on the increasing urbanization of Toronto and its growth in high-rise areas. With high household incomes and a predominantly single lifestyle, these residents have time and income to pursue active social lives. This is why neighborhoods such as Liberty Village are often filled with not only condos but many types of recreational establishments such as cafes, boutiques, bars, fitness studios etc., creating a fast-paced and dynamic daily environment. Through the rising trend of organic food stores and restaurants in the neighborhood it is also evident that residents of Liberty Village try to be ecologically aware and keep a health-conscious mindset. ${ }^{17}$
Digerati is a recent term used to describe the elite of the computer industry and online communities. It is a merging of the words digital and literati. People who fall into the category of digerati include computer scientists, tech magazine writers and bloggers.

(Wikipedia)

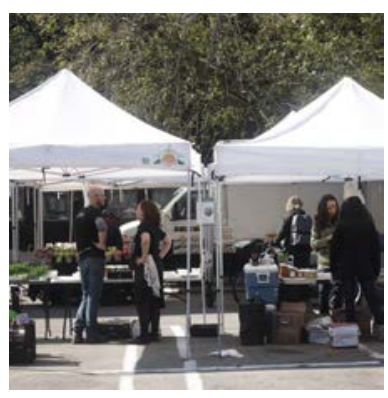

IMAGE 28 . Through the months of June to November, the 'My Market Liberty Village' building uses holds an outdoor farmers market every Sunday. 
"work . play . live"

This is the maxim that the LVBIA has attributed to Liberty Village in order to cultivate a creative and vibrant community. In the site analysis presented earlier, we can see that there are many distinctions to be drawn between the east and west, not only in terms of heritage preservation and density, but in partition of programs across the site.

- The Liberty Village Business Improvement Area is an organization committed to the creative and cultural development of Liberty Village and its promotion in the city. ${ }^{18}$ The commercial buildings are concentrated in the center, linking both sides of the neighborhood. The west contains the mixed-use buildings which hold most of the remaining industrial character of the region, but also many of the recreational activities of the neighborhood. However in the east end Liberty Village becomes almost entirely new construction residential.

The disparate concentration of programs in Liberty Village will serve as an important factor in establishing a program for the adaptive reuse of the Toronto Central Prison Chapel. In addition to the much needed authentic character that the prison chapel brings to the east, its central location provides the opportunity for an engaging and unique new program. 


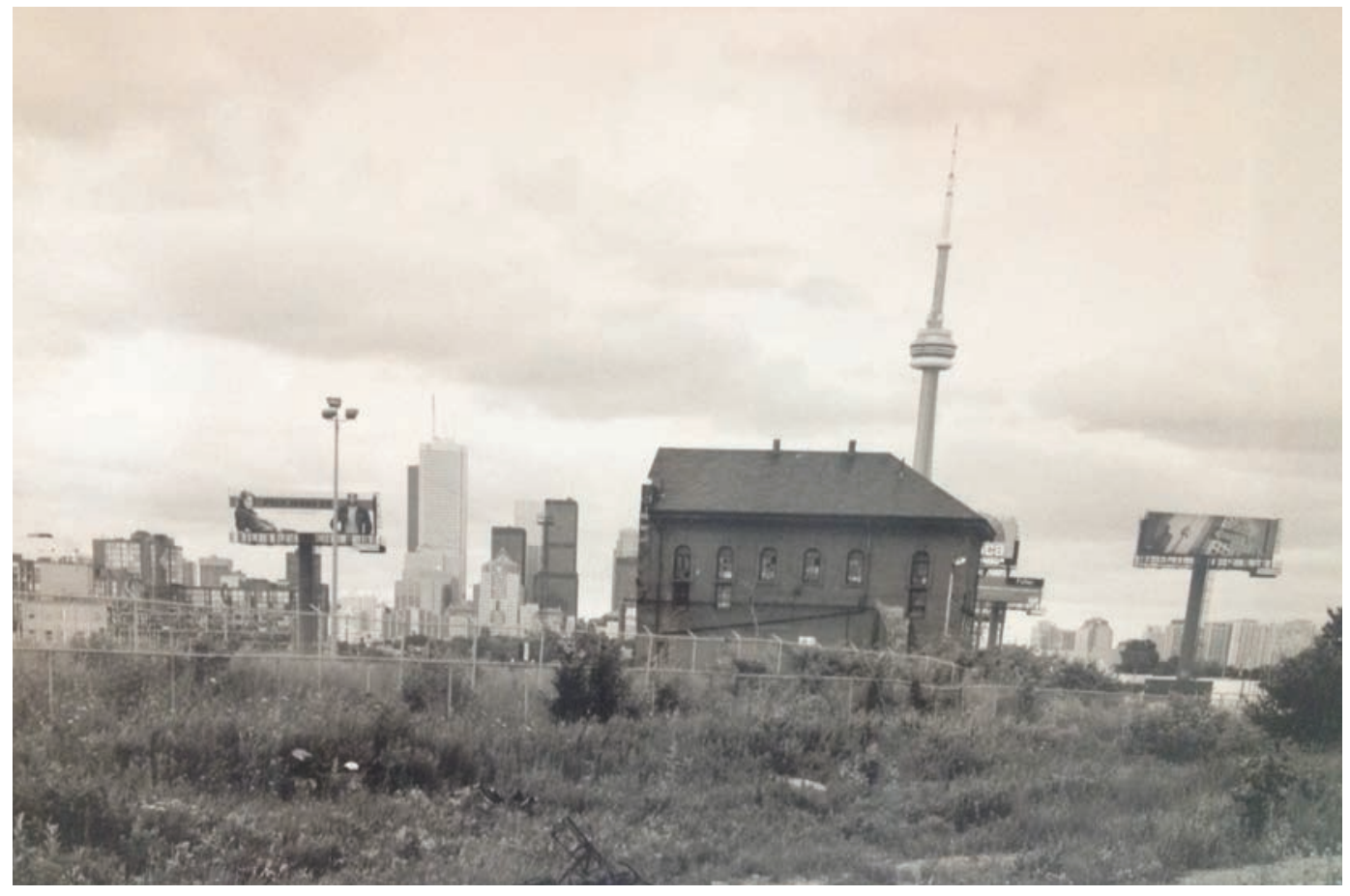

IMAGE 29 . Toronto Central Prison Chapel, 1995 


\section{3 | Toronto Central Prison Chapel}

The Toronto Central Prison Roman Catholic Chapel was built as an addition in 1877 by the inmates of the Toronto Central Prison. The Central Prison was built in 1872 as a penal institution to accommodate industrial training in a self-sustaining correctional facility while taking advantage of the industrial location and nearby network of rail lines. Designed to house a maximum of 600 prisoners, it was filled to capacity by the early 1900 s. In 1915 the Central Prison closed and its remaining structure was occupied briefly by the Canadian Army as a garrison and training facility during World War I, followed by a quick stint as a processing facility for new immigrants. ${ }^{19}$ Five years later, the buildings were sold and the centre block and wings were demolished, leaving only the prison chapel and a few remaining buildings. These structures were sold and subsequently used by a series of manufacturers including Hobbs, Dr. Ballard's, and most notably John Inglis and Sons. ${ }^{20}$ Following the closing of the Inglis plant in 1985, the Toronto Central Prison Chapel was vacated and has stood unoccupied despite several development proposals. It stands empty today within a small public park and as such represents a fragment of the dominant past Liberty Village.
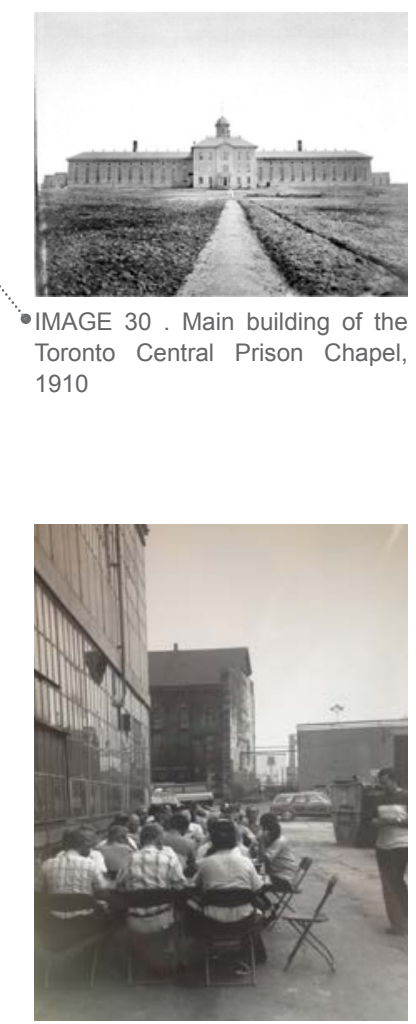

IMAGE 31 . Inglis factory workers having lunch with the prison chapel in view, 1965

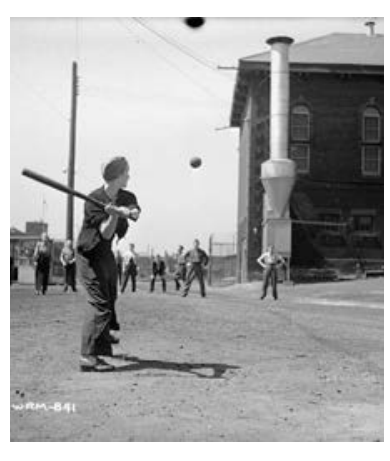

IMAGE 32 . Veronica Foster, Canadian icon known as "Ronnie, the Bren Gun Girl" represented the nearly one million Canadian women working in manufacturing plants during WWII, 1942 
The Toronto Central Prison Chapel was added to the city's list of Heritage Properties in 1985 and was designated under Part IV of the Ontario Heritage Act in 1996. This act protected the property from alterations to the identified heritage elements. Requests to alter these

See Appendix A. City of Toronto By-Law No. 1996-0378: schedule "A" and schedule "C" the permit is refused, a 180 day "cooling off" period is required which is intended to allow time for the landowner to negotiate a better heritage conservation strategy. Unfortunately, this strategy did not prevent demolition of said elements once the 180 days had past. ${ }^{21}$ As of 2005, the provincial government sanctioned changes to strengthen the Act and protect heritage buildings further. Today, upon the refusal of a demolition permit, a landowner has the option to appeal the permit refusal to the Ontario Municipal Board for a final decision. Should the OMB refuse the permit, the site is deemed protected by legislation and would require owners of designated buildings to maintain them in order to prevent "demolition by neglect". 22

The Toronto Prison Chapel at 20 Strachan Avenue in Liberty Village now stands as one of the two remaining heritage protected buildings which formerly made up the Toronto Central Prison (the other being the A.R. Williams Machinery Building). The chapel has however remained vacant since the closing of the Inglis Plant in 1985, with several plans to convert it having come and gone since then. Modernization can be read in the Toronto Central Prison Chapel from its beginnings as a place of faith in a city which had not yet felt the full push of capitalism to its use in a collection of factory buildings during the age of industrialization in Toronto.

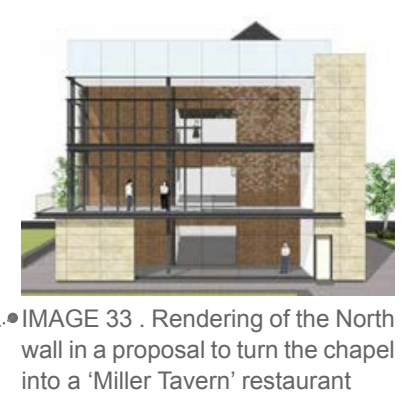




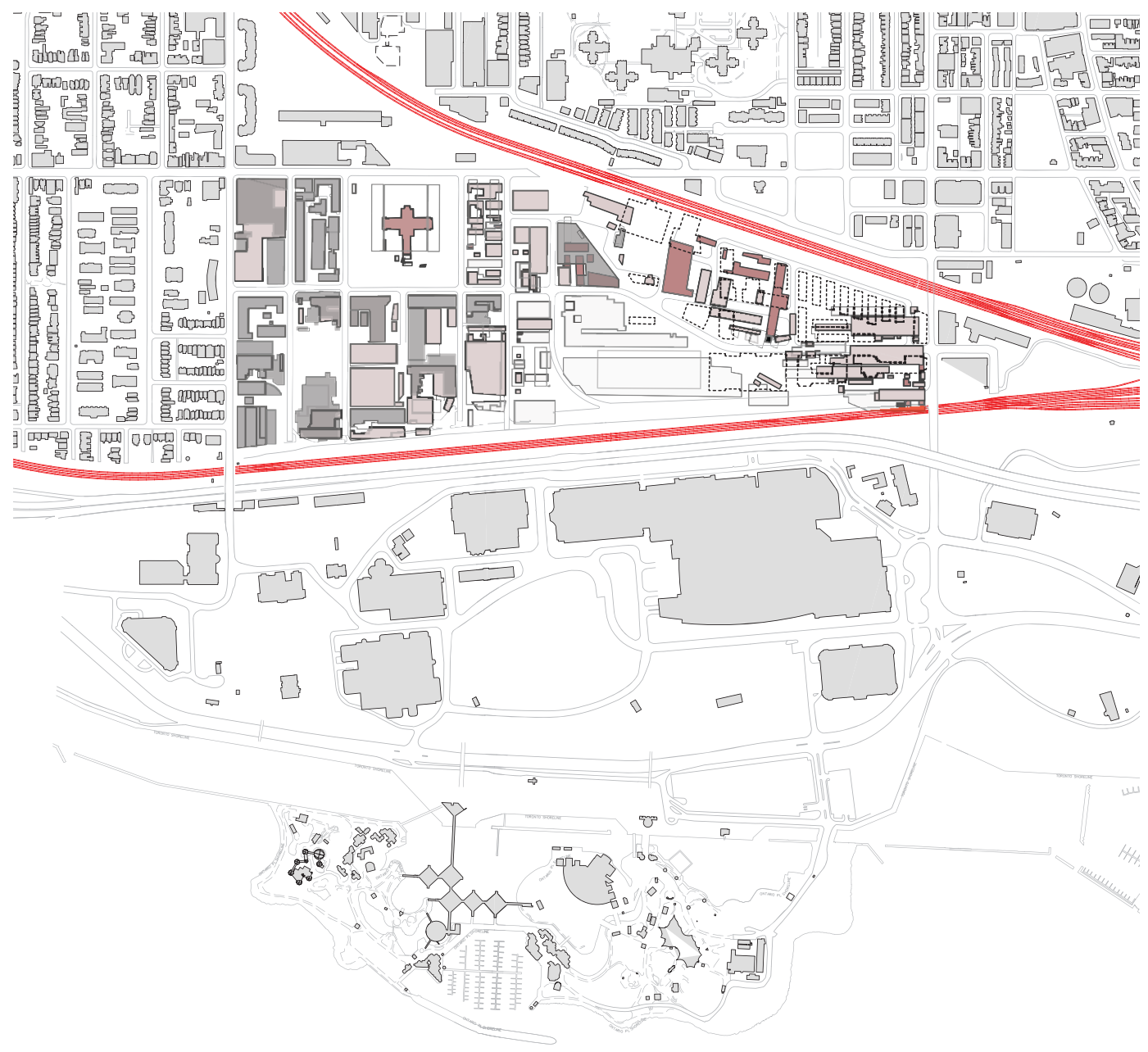

The analytical mapping made using aerial images of Liberty Village since 1899 shows the growth and decline of the prison complex and industrial buildings in its vicinity throughout the last century. Through this mapping we see the chaos of destruction and renewal around the Prison Chapel over time.

The dotted lines show building footprints as they exist today. The gradient of the footprints informs the timeline of construction in the neighbourhood, with the darker outlines delineating older buildings and vice versa, with the exception of the red forms showing the first buildings built on the site prior to 1900 .

See Appendix B. Liberty Village aerial maps 


\section{DEFINING CHARACTERISTICS}

Designed by Irish architect Kivas Tully to complement the adjoining centre block and wings of the prison complex, the prison chapel is designed in the Renaissance Revival style popular to Toronto in the mid to late 19th century. ${ }^{23}$ The two-storey load-bearing brick envelope supports a hipped roof decorated with paired wood bracket that extend beneath the eaves. The east, south and west walls are decorated with brick quoins, stone labels and sills and round-arched window openings adorned with detailed stone keystones and corbels. Some of the window openings have been altered and extended due to the conversion of the building to industrial use. Though it currently sits empty among a forest of towering glass-clad condominiums, the prison chapel has retained the authenticity and integrity of Toronto's founding architectural language.

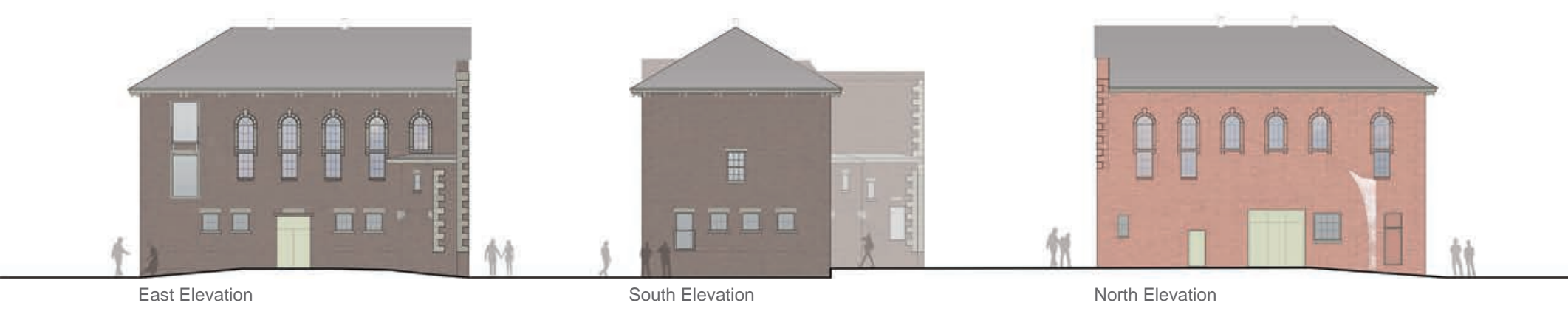




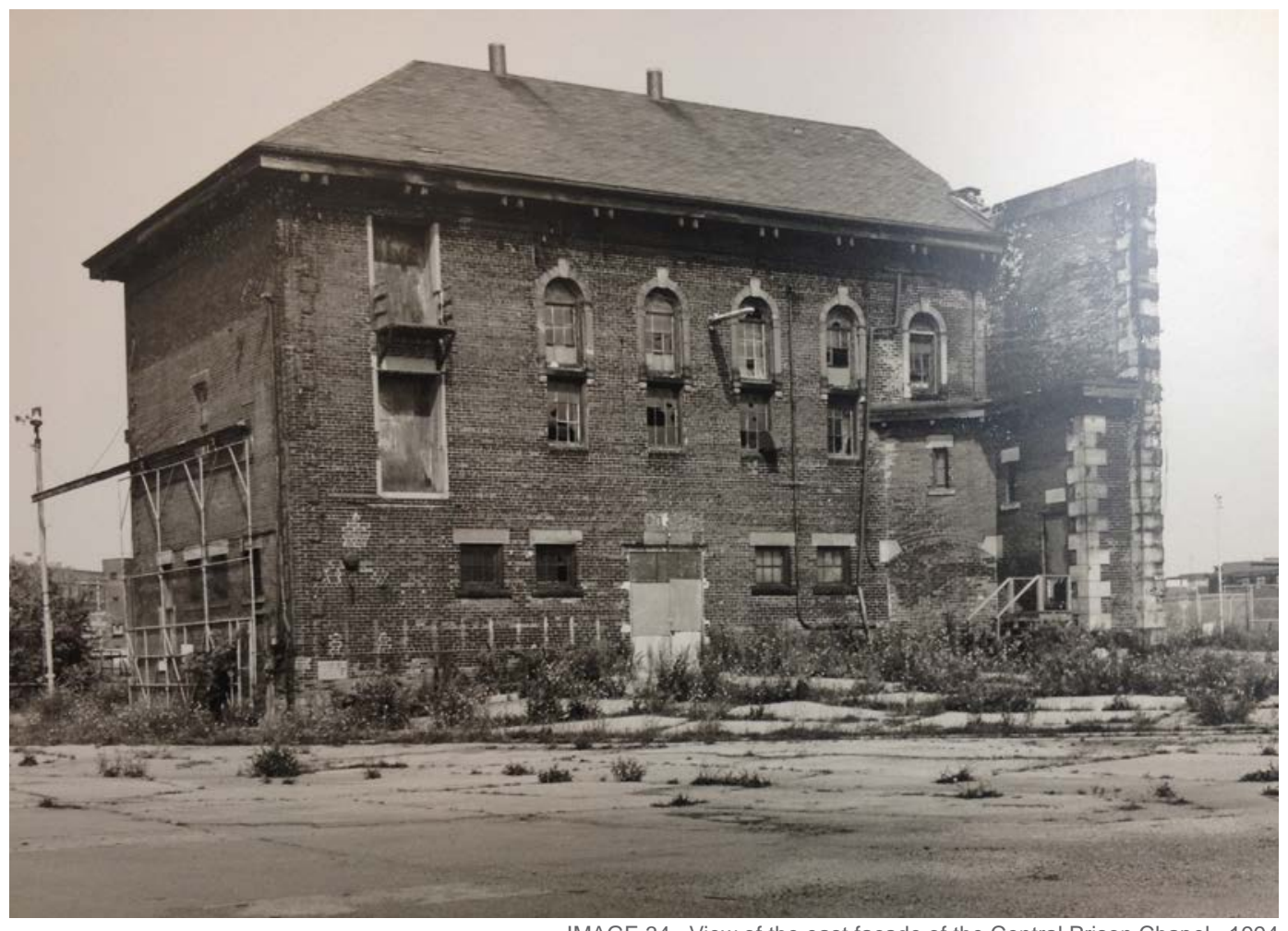

IMAGE 34 . View of the east facade of the Central Prison Chapel, 1994

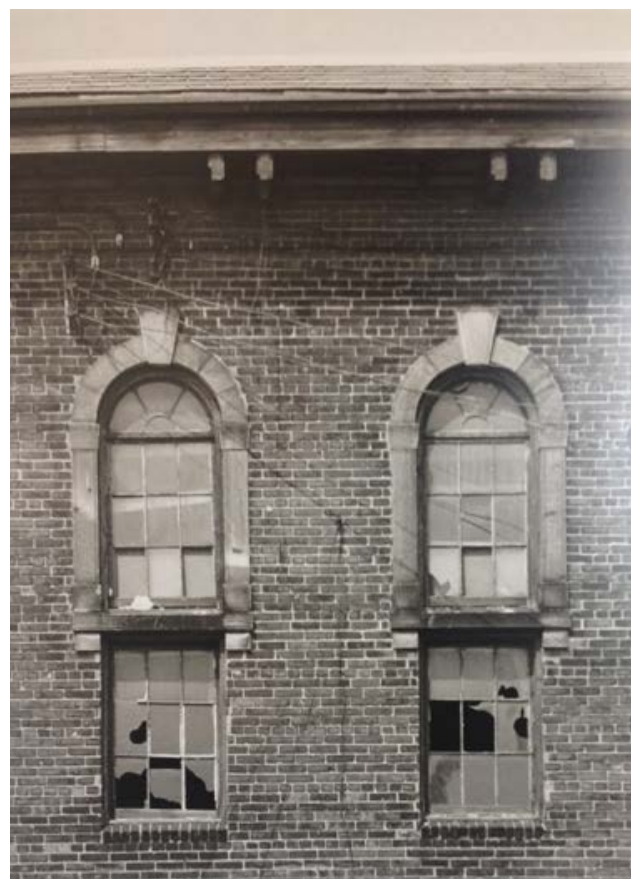

IMAGE 35 . Detailed view of the east wall of the chapel showing two of the round-headed window openings.

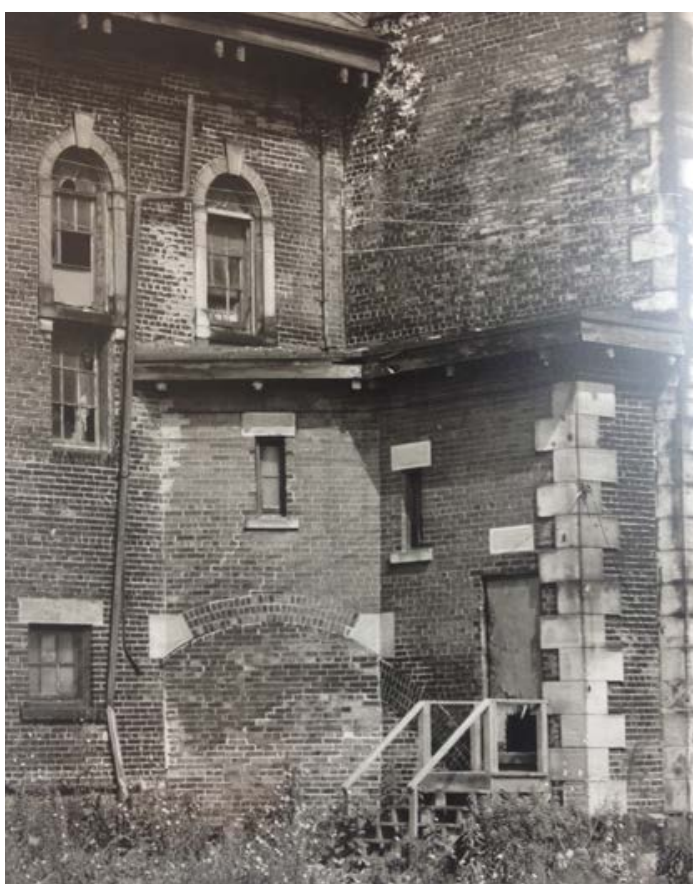

IMAGE 36 . Detailed view of the east wall of the chapel where it meets the south wall of the Central P 


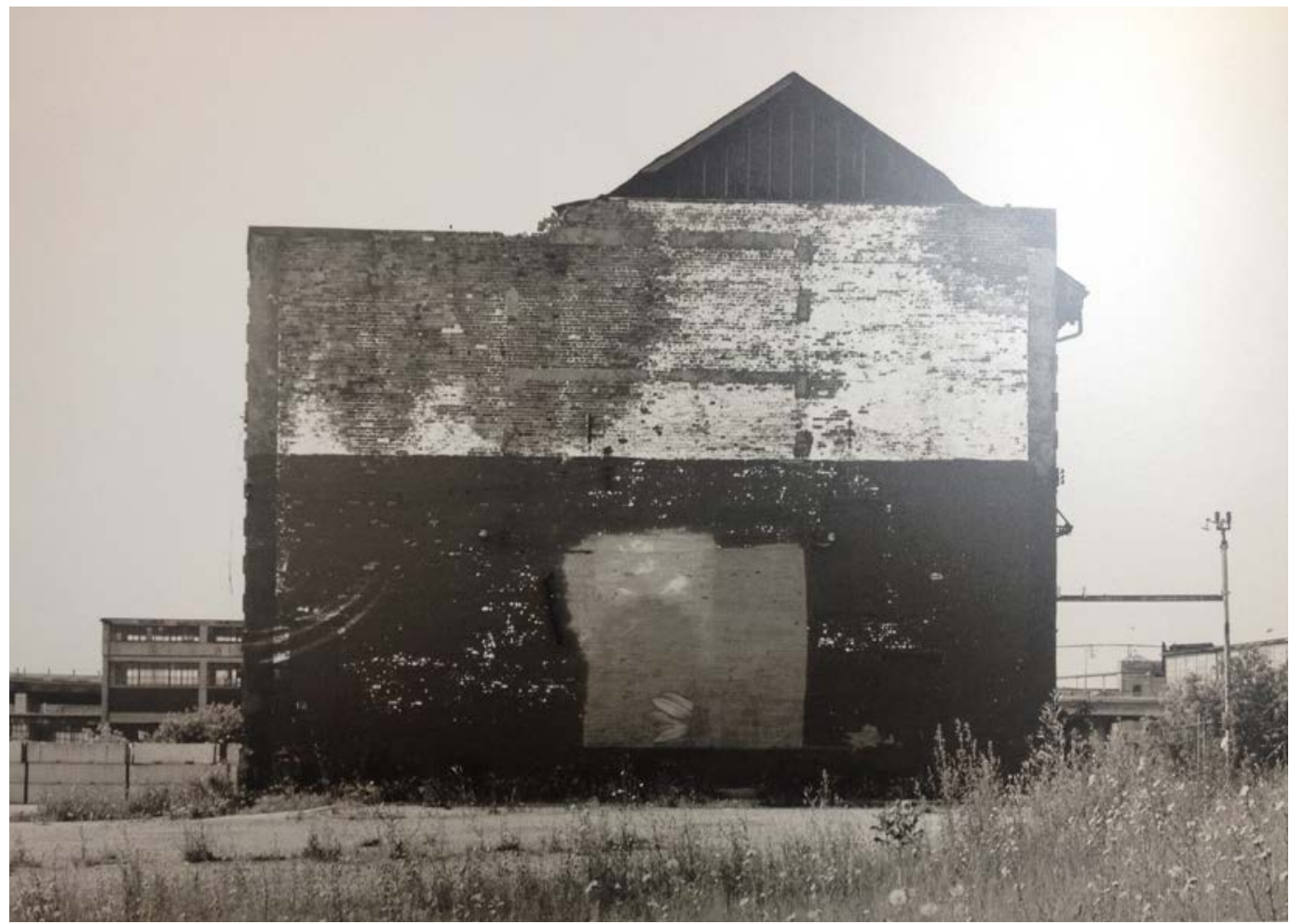

IMAGE 37 . The North wall of the Prison Chapel was a party wall that connected the Chapel to the South wing of the Central Prison. The hip roof of the Chapel rises above the wall. As it was previously part of the Central Prison, the North wall is thus the oldest element of the Prison Chapel. One can see remnants of the chapel's architecture and its changes over time through a layering of stories evident in the changes in paint, brick, and consistency of wall elements. These details inform us of the realities of its unseen past as a chapel, immigration center and industrial building. 


\section{ENDNOTES}

1. Arthur, Eric Ross. Toronto, No Mean City. University of Toronto Press, 1986., p. 43

2. "The History of Toronto: An 11,000 Year Journey." Accessed November 16, 2014

3. ibid.

4. ibid.

5. Wieditz, Thorben. "Liberty village: the makeover of Toronto's King and Dufferin Area." Centre for Urban and Community Studies, Toronto (2007).

6. "Liberty Village BIA - BIA Listings - Business Improvement Areas / City of Toronto," Accessed February 4, 2015.

8. "After 21 Years, Artscape Liberty Village Closes." Artscape. Accessed March 12

9. Thorben. "Liberty village"

10. ibid.

11. ibid.

12. Hume, Christopher. "Liberty Village Highlights Poor Planning". Toronto Star. March 8, 2008.

13. "Condo Showdown: Five Liberty Village Units for Under $\$ 550,000$ ". Toronto Life. June 11, 2013

14. Liberty Village BIA

15. ibid.

16. City of Toronto Neighborhood Profiles 2011 "Niagara (82)." Accessed March 23 2013.

17. Liberty Village BIA

18. ibid.

19. "Alteration of a Designated Heritage Property - 70 East Liberty Street (Central Prison Chapel)." Accessed March 7.

20. ibid.

21. "Ontario Heritage Act." Service Ontario. Accessed November 3, 2014 $<$ http://www.e-laws.gov.on.ca/html/statutes/english/elaws_ statutes_90o18_e.htm>

22. ibid.

23. "Alterations of a Designated Heritage Property" 


\section{Chapter 4: Veil of Modernity}

\section{veil of modernity}

concept

1.

of or relating to the transitory, fleeting or fortuitous quality of present urban architecture built over historical roots of a city to meet changing demographic needs

2.

temporary, adaptive, uninvasive 
The veil of modernity is a concept defined by the presented notion of modernity in Chapter 2 as the destructive character. The proposed design uses the impermanent and changing quality of modernity to inform an adaptable structure which follows a cycle of assembly and deconstruction. A new skin wraps around the prison chapel but because of its open form and stark contrast in material, it emphasizes the distinctive features of the prison chapel envelope rather than covering them. This new skin is inspired by a scaffolding morphology that draws from the recent dramatic intensification of built form in the area and addresses the temporal condition of such a structure, while the utilization of wood adds a new and inviting character to the site. Straddling the dichotomy between authentic and modern, a new vernacular of architectural language is established for Liberty Village.

In warmer months, residents of the area take to the park in which the prison chapel is located to walk their dogs. The few who have small children take them to the playground structure. However for the majority of the year, and especially in the winter, the park stays vacant as residents opt for the different programs offered in the central and west portions of Liberty Village. The Liberty Village Arts Court presents an adaptive program in the east end that will engage the community of Liberty Village while catering to its demographic needs. The Arts Court is a place of interaction, an urban garden, an interim exhibition and a return to a lost authenticity. The North wall serves as the central point in the design and the element which conceptually links the history of the prison chapel to the modern life of Liberty Village residents.

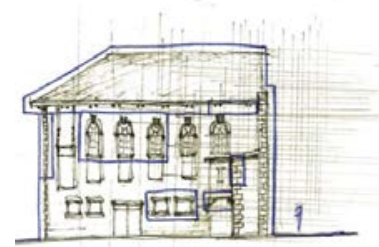

Concept Iteration 1. A steel veil perforated by glass openings clads the structure, protecting its envelope from external elements and revealing key architectural details.

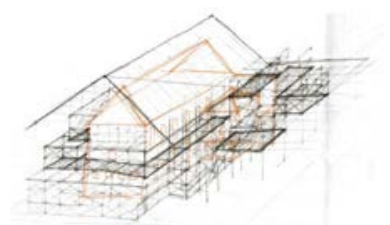

Concept Iteration 2.

A steel scaffolding structure sits around the building and beneath a new roof with walkways and platforms containing varying programs. 
The grounding truth of authenticity is the root of our being that informs who we are, and the truth in a city's language can be found in its built heritage. This built heritage speaks to a city's culture and tradition and plays a key factor in establishing its identity. Despite the guidelines presented on defining authenticity in the Nara Document, authenticity at large remains subjective when speaking on additions to original buildings.

In the case of the prison chapel, the elements that we can ascertain were present in the original chapel are the brick envelope and supporting roof structure complete with the under-eave brackets. The interior floors and roofing envelope were later additions to the building and do not contribute any information as to its history that the North wall does not, which is why they have been removed from the proposed design. The interior walls are stripped bare to their original state as the bones of the structure are revealed. The East, West and South elevations will be preserved to their fullest potential, with the only exceptions being the second-storey windows. One longer window on each side of the building will be used as a door connecting the interior of the building to a third storey walkway, as seen in Section A-A. The roof structure and its details have been kept and added onto in order to enrich the quality of space inside the building. The authenticity of built heritage is especially important in an area such as the east end of Liberty Village, where the destructive character of modernity has erased almost all traces of Toronto's founding language. 


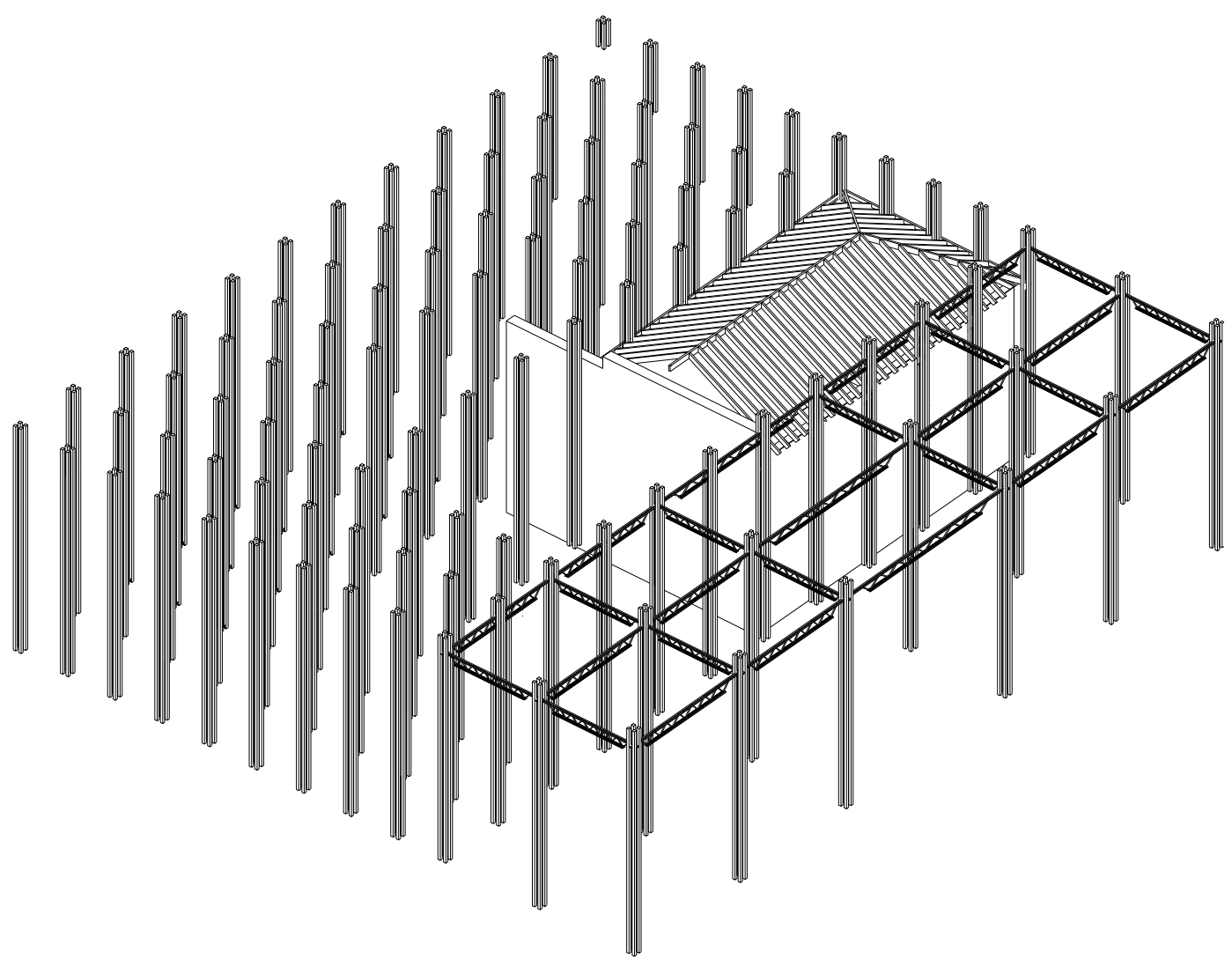

// Supporting structure

The structure relies on a framework of column and beam construction with the exception of the western portion of the design that contains a system of steel trusses and cables for added support. This portion differs from the rest of the structure as the program which it holds is temporary. For that reason it is constructed in a way that is removable in order to make better use of the space it occupies. In the warmer months, the system of steel trusses and cables serve as additional support for a series of walkways and garden planters. These are rented yearly by the residents of Liberty Village and tended to between the months of March and October when the structure is erect. In the months they are not in use the planters are sealed and stored in the basement of the prison chapel. The rest of the structure consisting of beams and walkways is removed, leaving only the concrete base columns and steel trusses above. The reason for this added structure is because several of the columns in the framework have been removed from the west portion in order to better accommodate the new program in the winter. During this time, the space below and that of the atrium is used to hold the skating rink. 


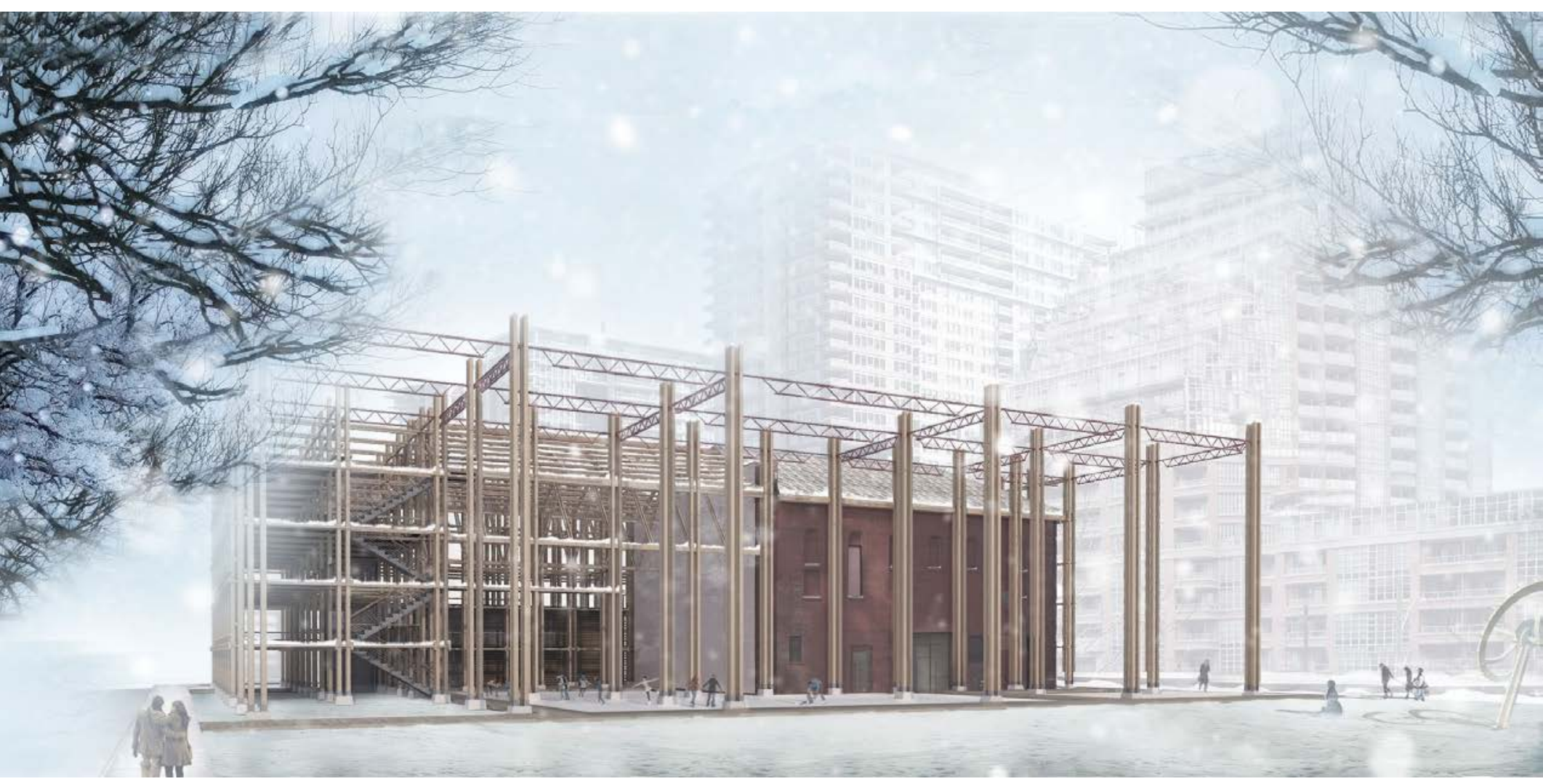

Rendering // View of the Arts Court in the Winter 


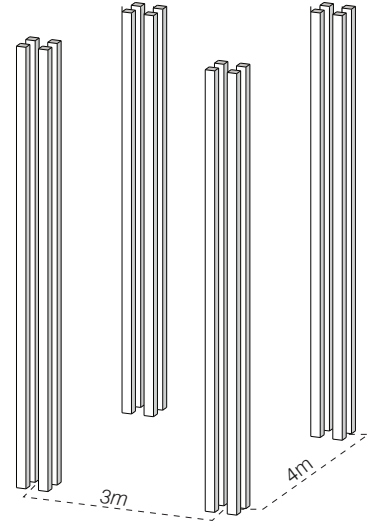

1 - $3 m \times 4 m$ framework consisting of four $15 \mathrm{~cm} \times 15 \mathrm{~cm}$ wood columns placed $35 \mathrm{~cm}$ apart o.c.

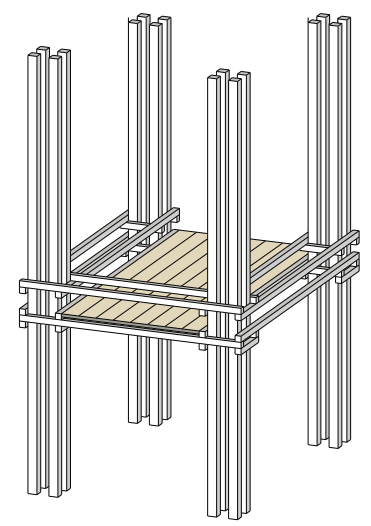

4 - additional beams anchored to sides of columns which will serve to support planters

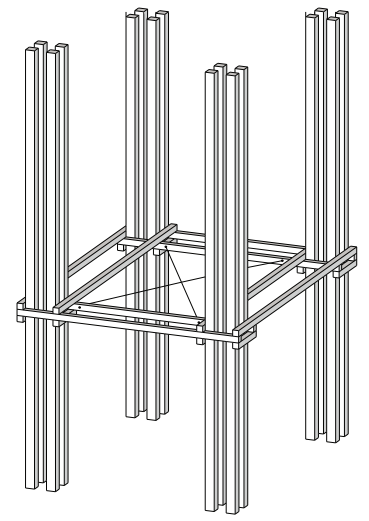

2 - beams are anchored to sides of columns at each level and $\mathrm{x}$-brace is attached to beams for added support

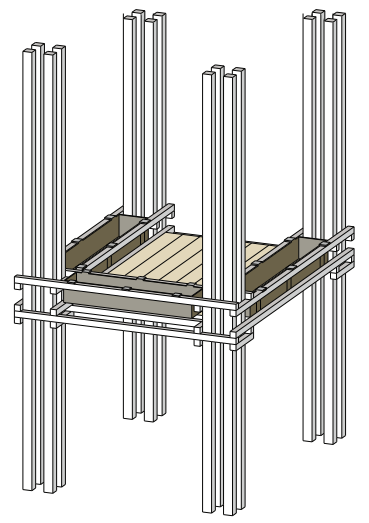

5 - planters measuring $70 \mathrm{~cm}$ wide are placed into spaces created by the beams

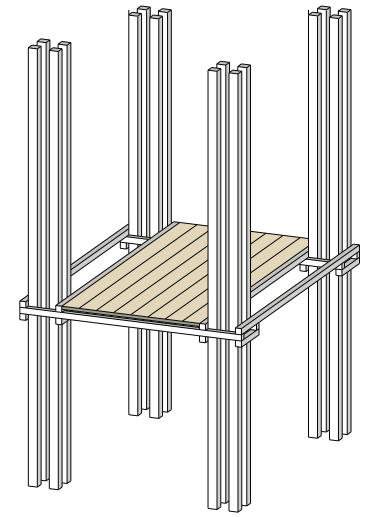

3 - dimensional lumber placed on beams and wires

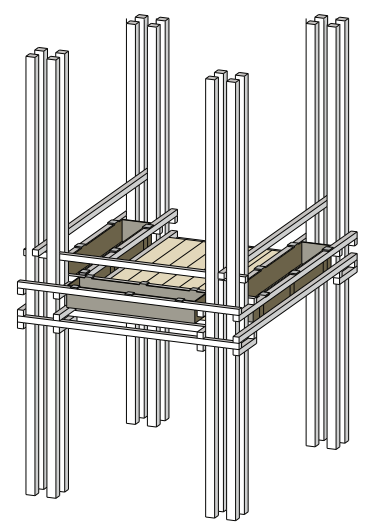

6 - wood beams added $30 \mathrm{~cm}$ above planters act as guard rails

\section{// Framework Structure}

The following diagrams show the construction of the framework structure containing planters. In units which do not contain planters, guard rails consist of steel and wires anchored to the base structure after step 3 . 


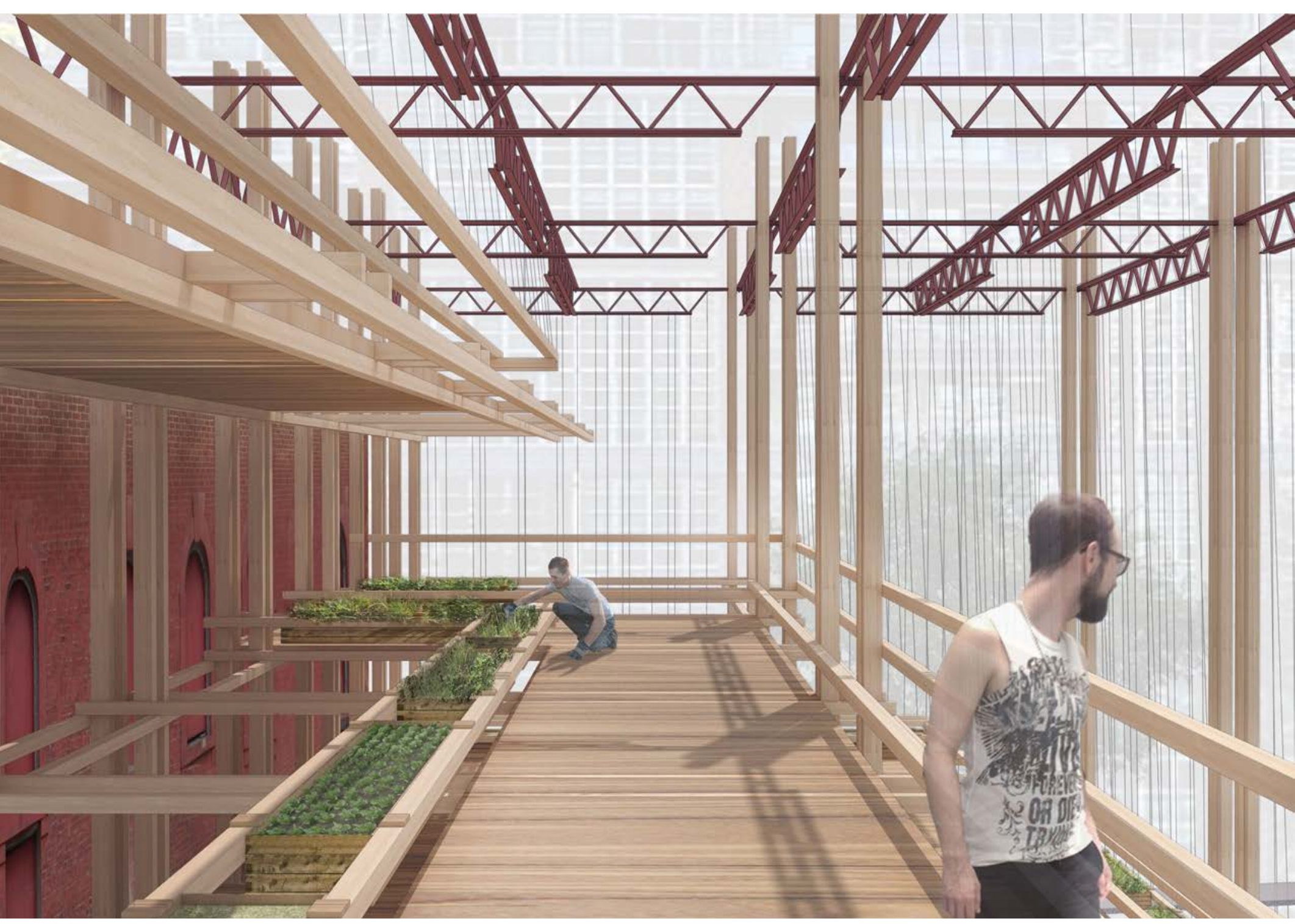

Rendering // View from the 4th floor walkway 


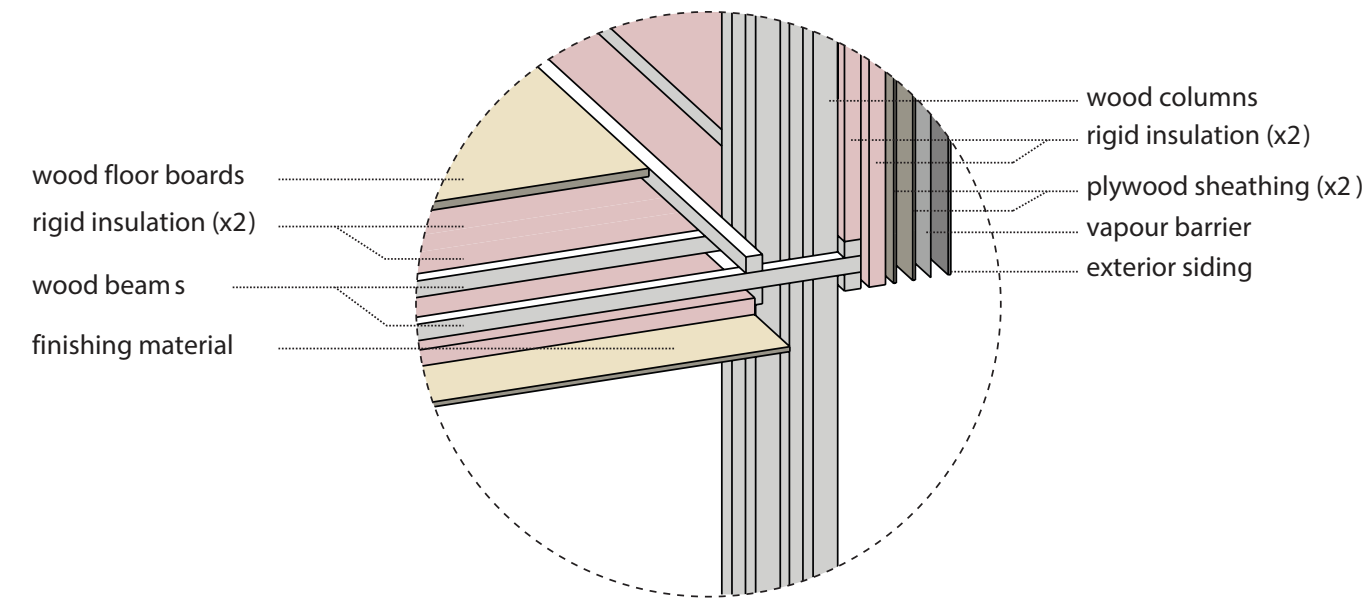

// Framework Structure

The diagram above shows how a structure pod can be converted from an exterior to an interior space. Spaces between and around the columns and beams are outfitted with rigid insulation then covered with finishing material anchored to the plywood sheathing. 

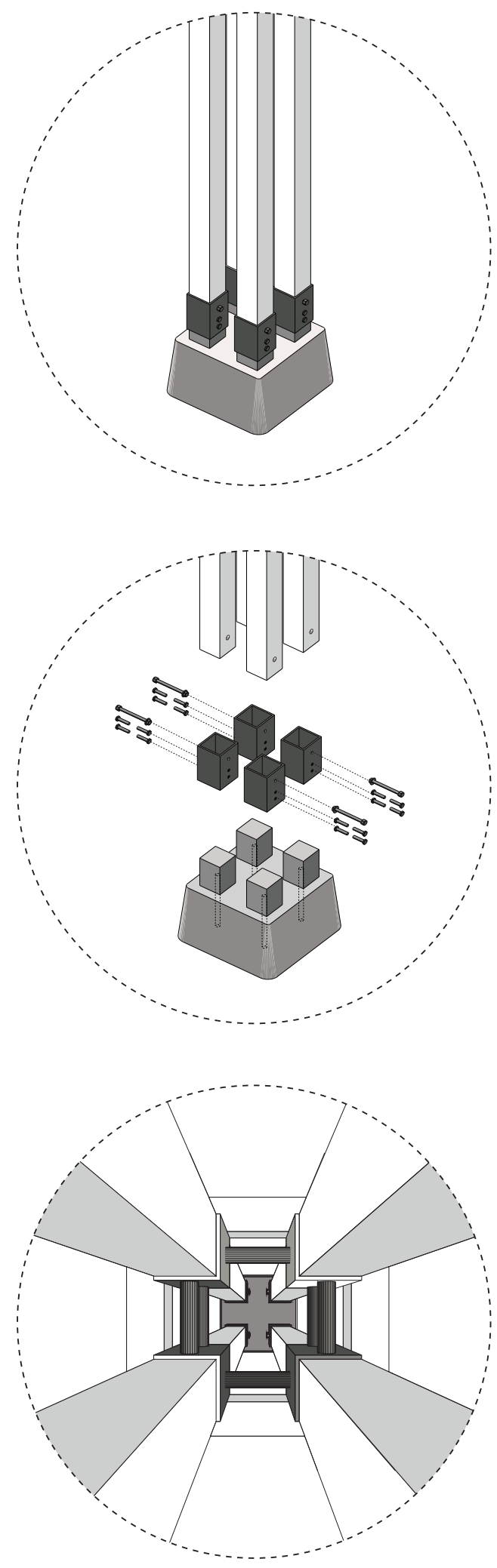

\section{// Column Structure}

The following diagrams show the assembly of a column group consisting of a concrete base to which steel tubing is attached. Anchor straps secure the steel to the column, and four glu-lam measuring $15 \mathrm{~cm} \times 15 \mathrm{~cm}$ are inserted into the tubing. At each subsequent floor level these wood columns are reinforced using steel angles connected using anchor straps and wood bracing. 


\section{// Roof Structure}

The existing roof structure (indicated in red on the diagram) is good condition and has been kept as the base structure for the new roof.

The original hip roof consisted of slate but was changed to ashpalt in recent times. These shingles and adjoining roof envelope has been removed and replaced by a glass skin that is held together using spiderglass attached to the existing rafters.

Between the existing roof and the new glass skin a layer of diagonal battens has been added to provide shade to the interior of the building.

Following the rhythm of the existing rafters, new glue-laminated timber rafters are added to extend the roof over the atrium space. These new members are supported by columns of the grid structure.

The following page indicates how the new glass cladding and wood battens are connected to the existing roof. 

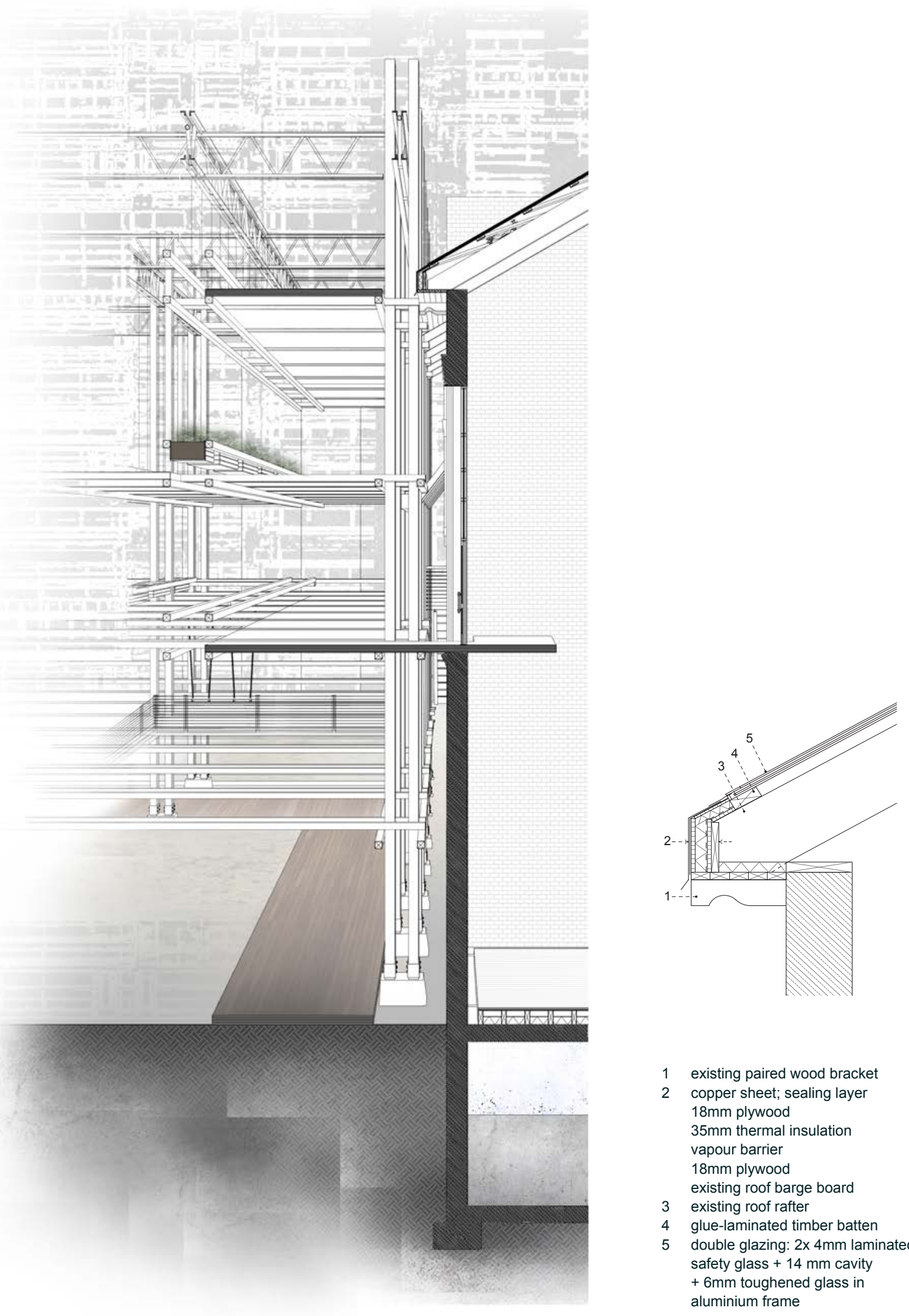

1 existing paired wood bracket

2 copper sheet; sealing layer

$18 \mathrm{~mm}$ plywood

$35 \mathrm{~mm}$ thermal insulation

vapour barrier

$18 \mathrm{~mm}$ plywood

existing roof barge board

3 existing roof rafter

4 glue-laminated timber batten

5 double glazing: $2 \times 4 \mathrm{~mm}$ laminated safety glass $+14 \mathrm{~mm}$ cavity

$+6 \mathrm{~mm}$ toughened glass in aluminium frame 


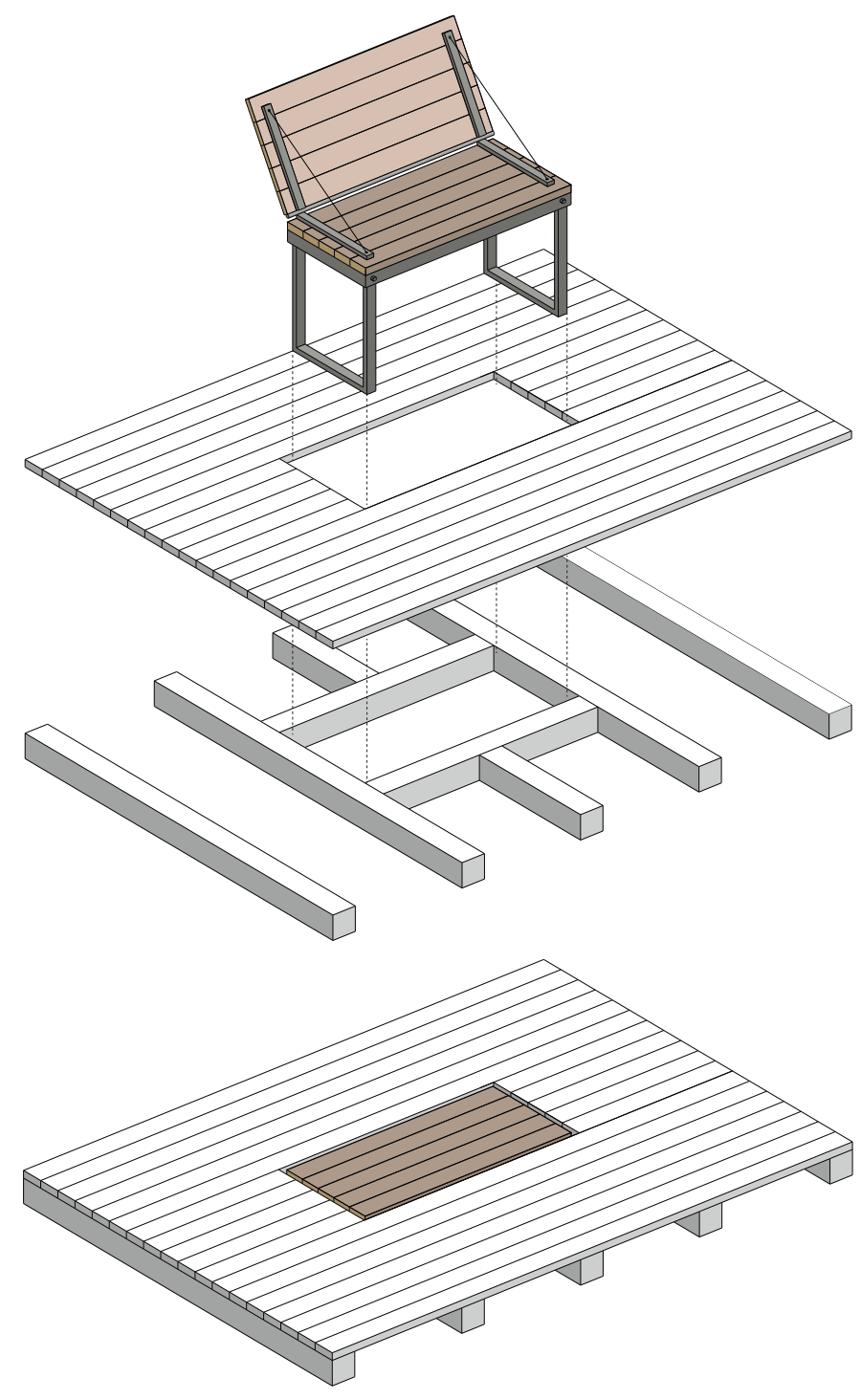

// Seating Structure

This diagram illustrates the exploded structure of a collapsable wood and steel bench in the main space. The wood bench is supported by steel members and cables when in use. When not in use the benche folds into itself and integrates into the wood floor of the atrium. The wood of the bench is different from that of the floorboards so that users will know their location. 


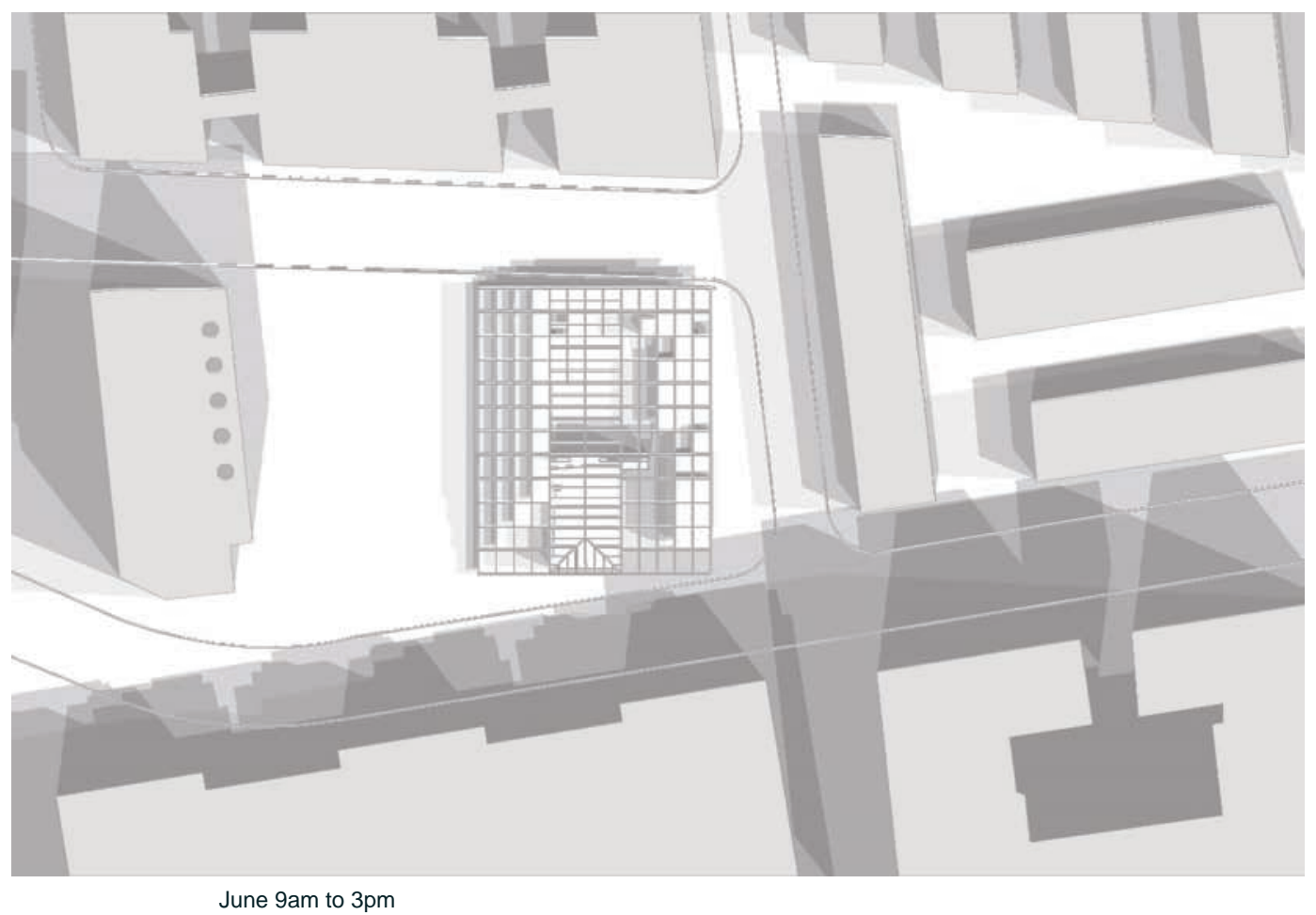

// Sun Studies

The sun studies show the shadows projected onto the site in the months of June and December. Analyzing these shadows is crucial to the location of the planters in the structure, which have been placed in locations for optimal sun exposure. These planters are indicated in the following plans as rectangles placed along the walkways and are oriented in such a way that the users receive maximum views of the prison chapel. 


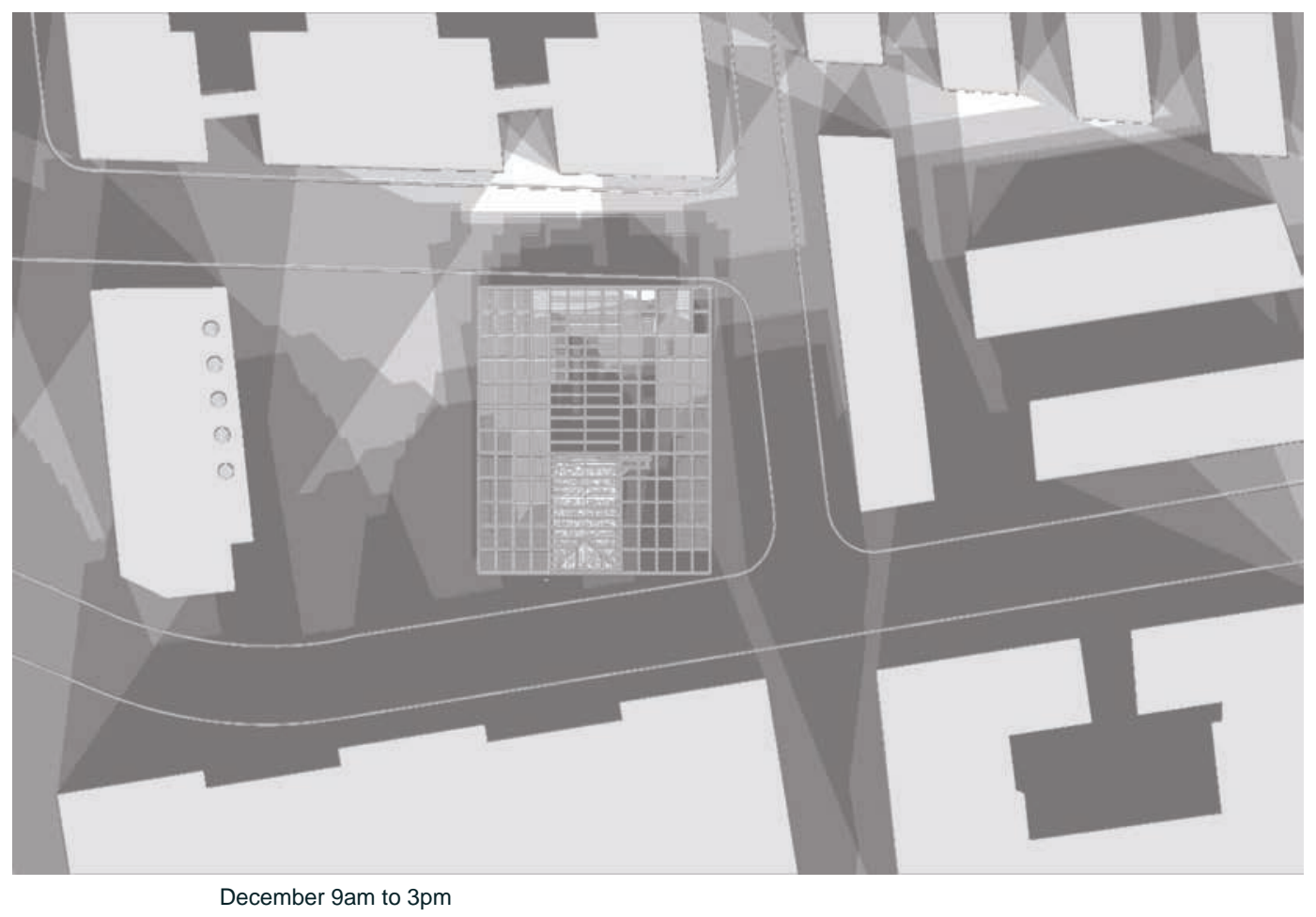




\section{Lynn Williams Street}

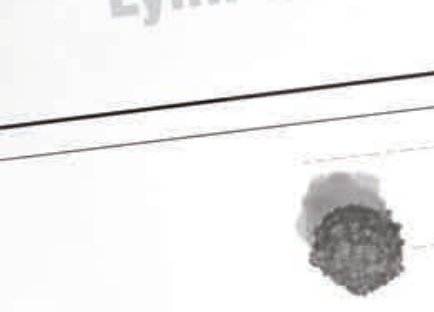




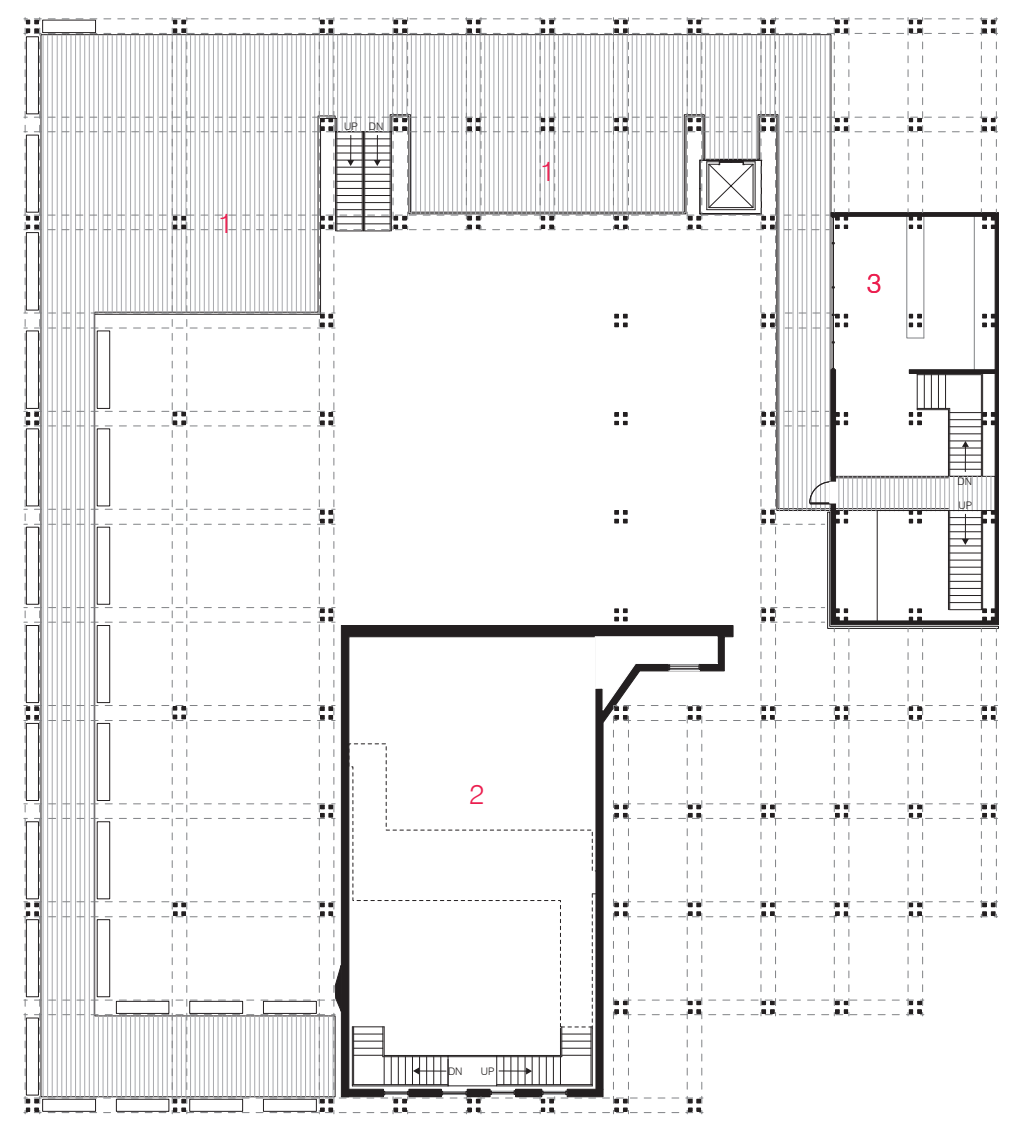

$\widehat{N}$

SECOND FLOOR

1 - gathering space

2 - exhibition space

3 - cafe below

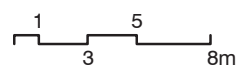


$:$

::

::

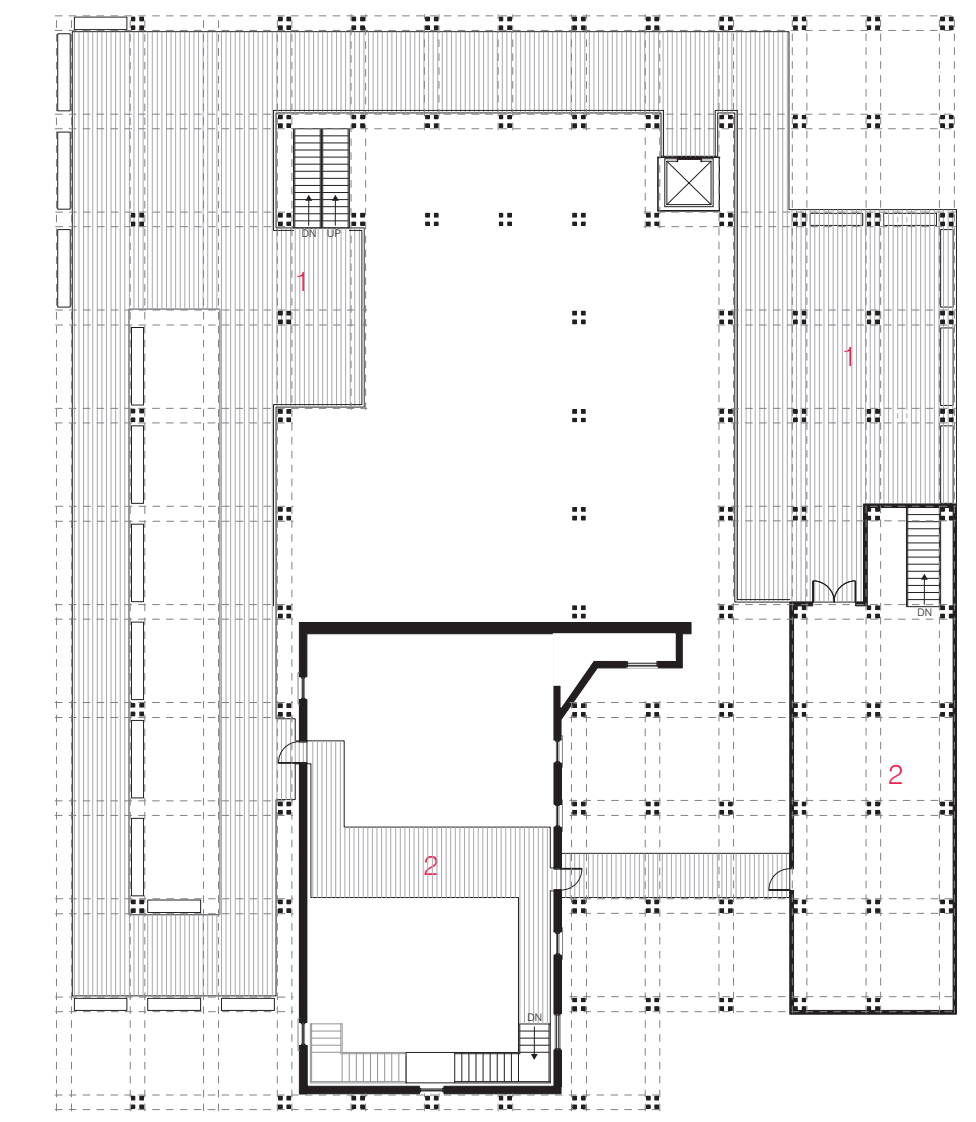

$\widehat{N}$

THIRD FLOOR

1 - gathering space

2 - exhibition space

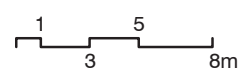


:

:

::

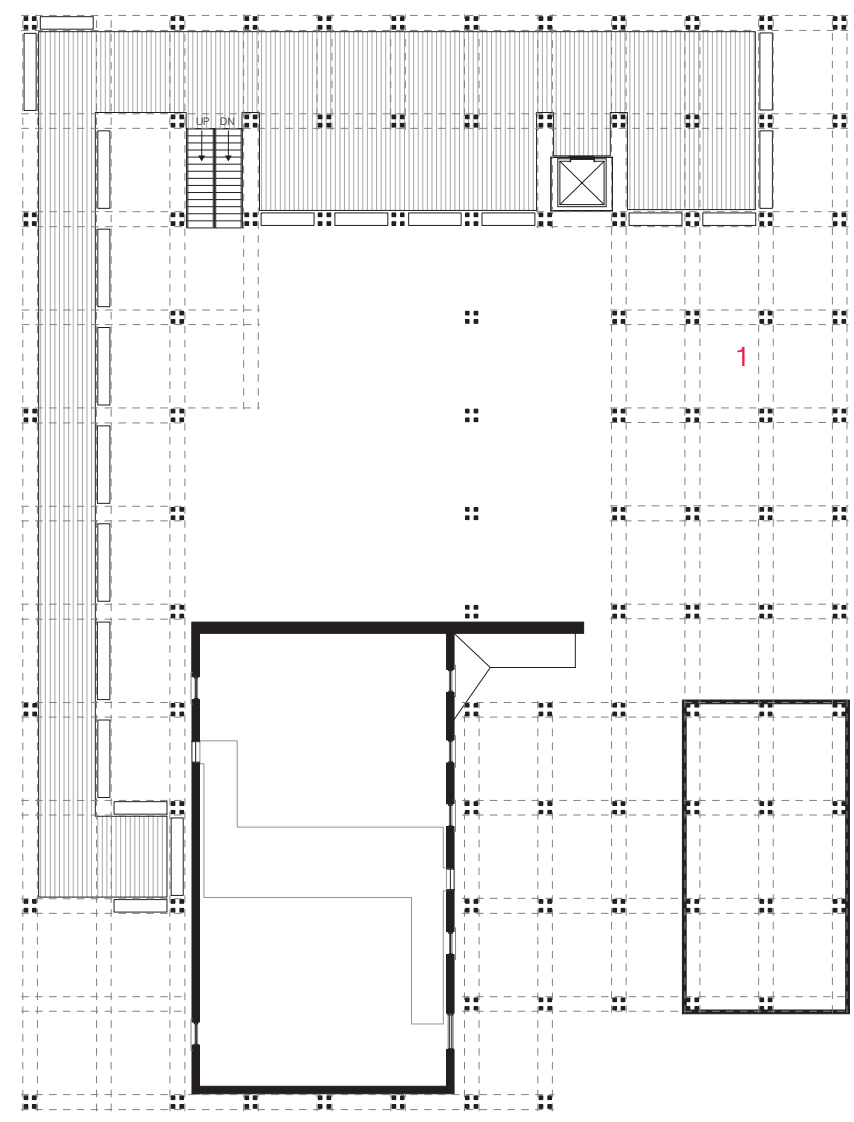

$\widehat{N}$

FOURTH FLOOR

1 - gathering space

2 - exhibition space

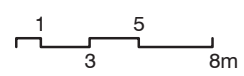


::

::

::

::

::

::

::

::

::

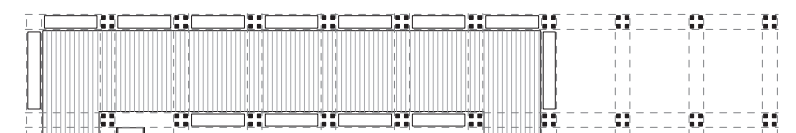

::
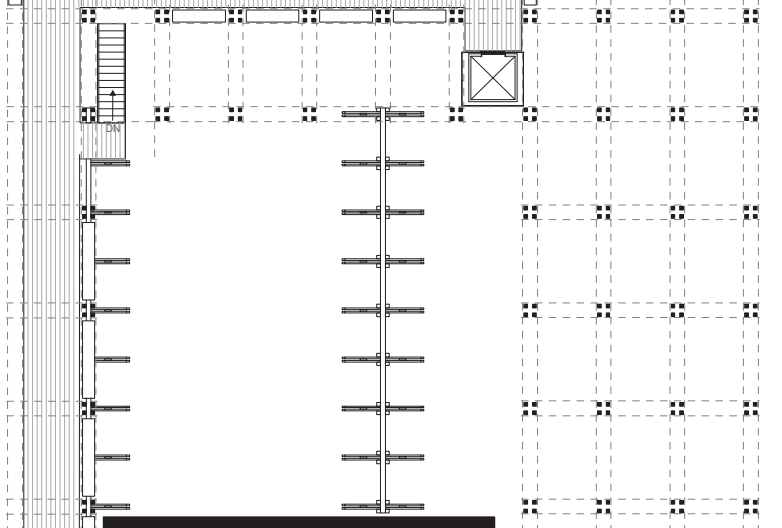

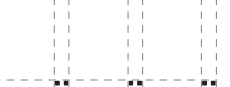

\begin{tabular}{ccc}
-1 \\
\hdashline
\end{tabular}

H

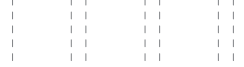

-

-

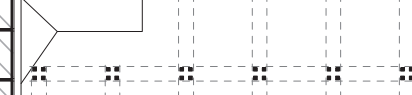

1

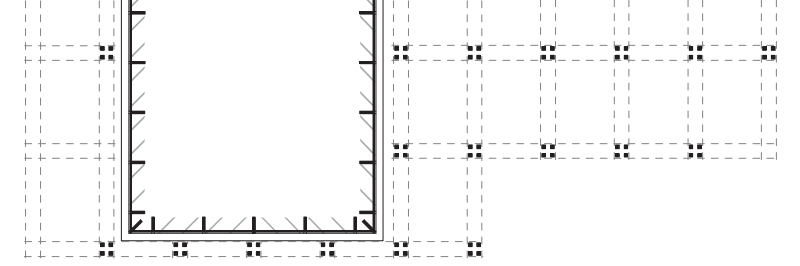

ㅅ

FIFTH FLOOR

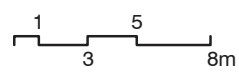




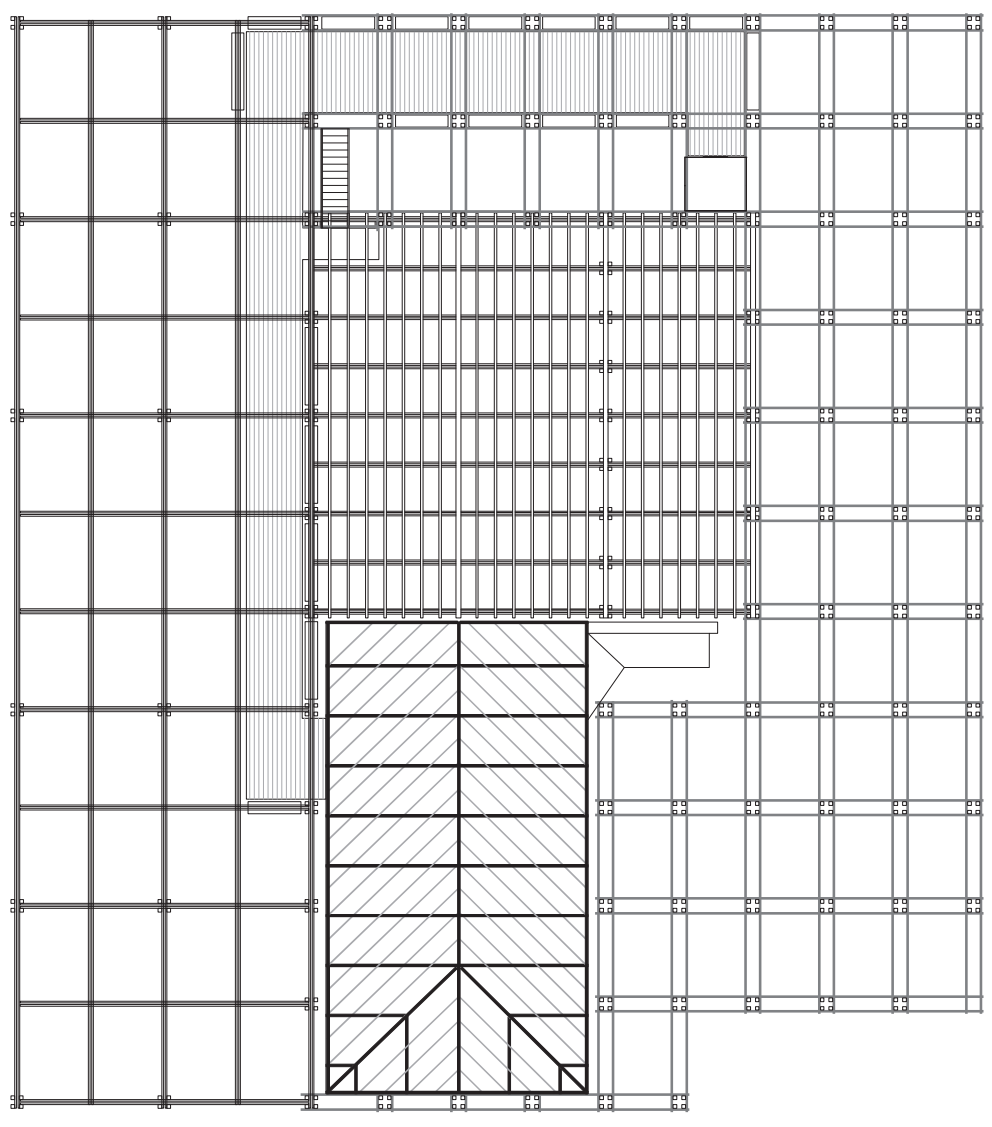

$\hat{N}$

AERIAL PLAN

$\overbrace{3}^{1} \overbrace{8 \mathrm{~m}}^{5}$ 


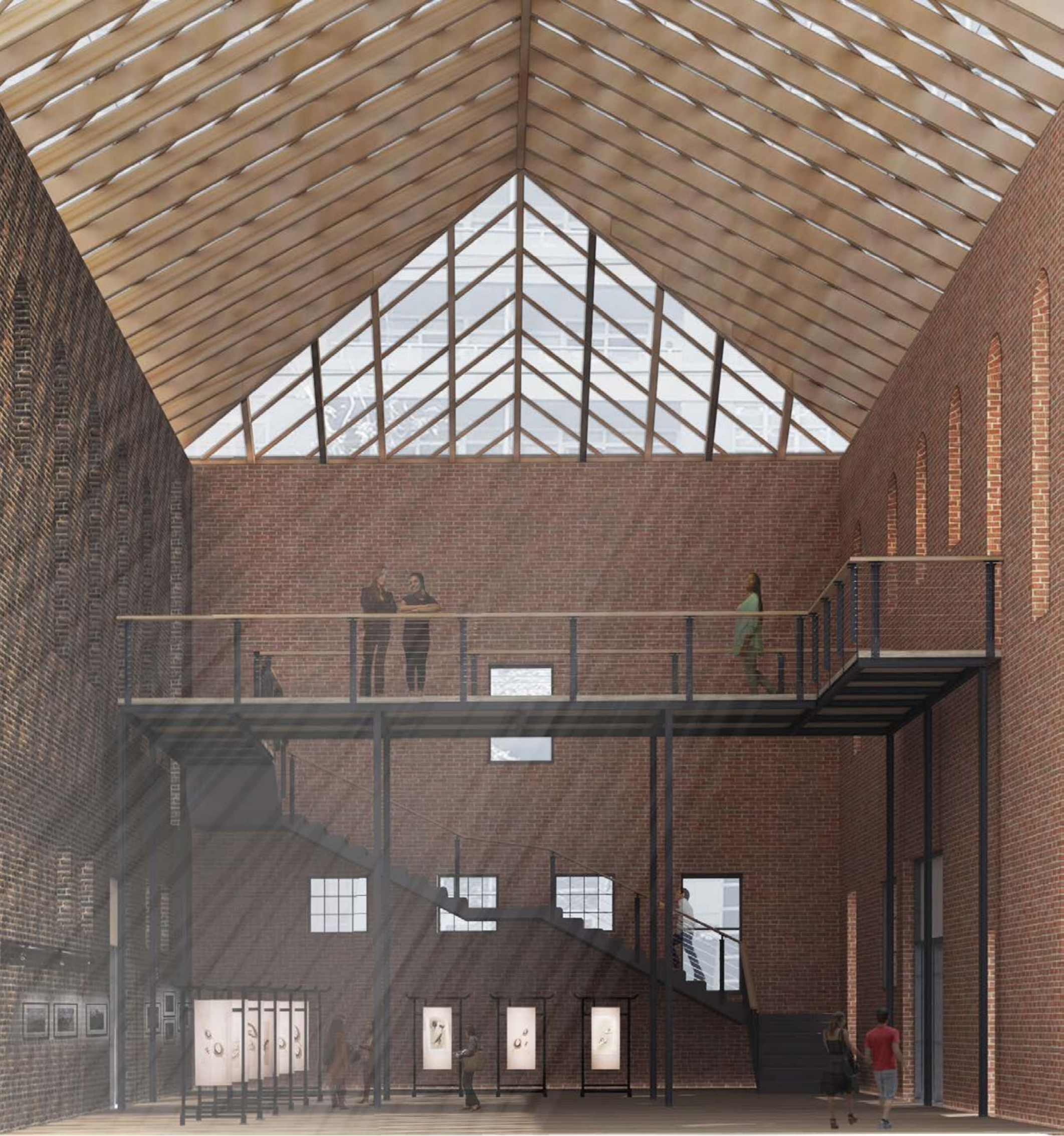

The interior of the chapel has been reverted to its original open form and stripped of any added finishes to reveal the supporting brick walls of the envelope. The lively play of light and shadows on the interior brick walls is achieved by the lattice-like wooden structure above. 


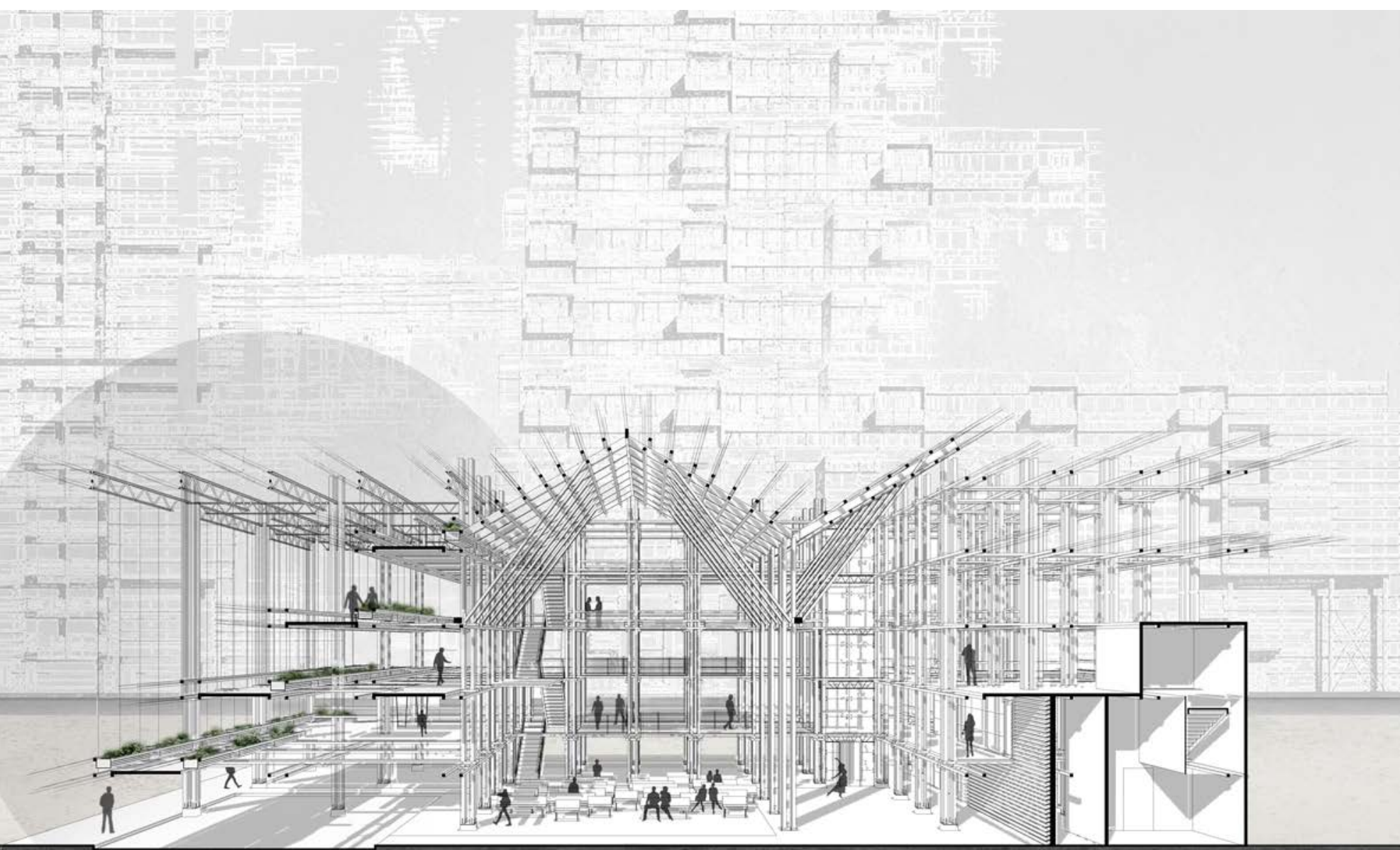

SECTION B-B 


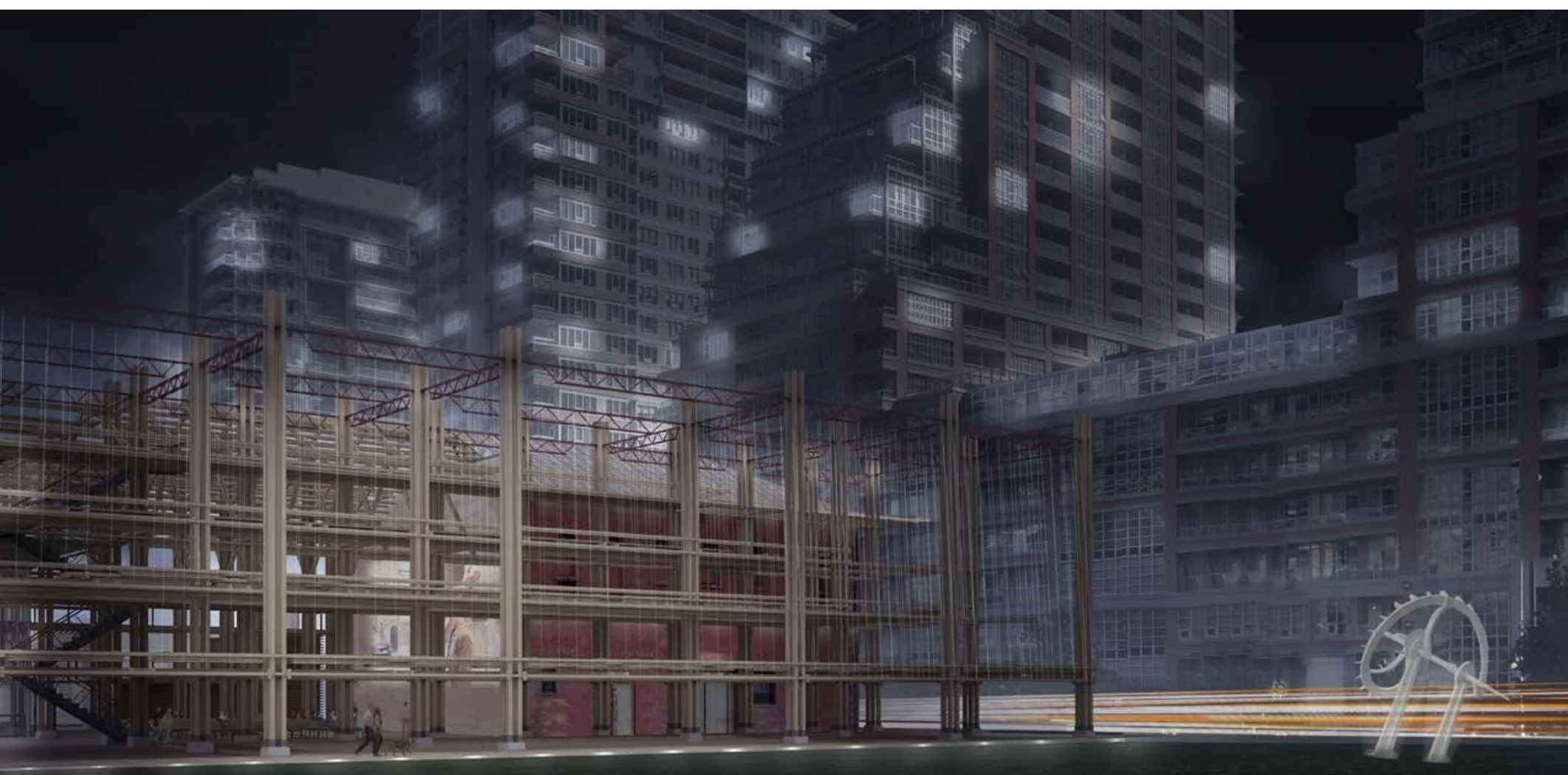




\section{CONCLUSION}

The veil of modernity is a concept informed by the explored themes of the authentic and the modern in this thesis. The design proposed uses the notion Baudelaire's famous interpretation of modernity as the fleeting to inspire a contemporary design intervention to the Toronto Central Prison Chapel in Liberty Village. The Liberty Village Arts Court is an adaptable structure informed by the destructive character that follows a cycle of assembly and deconstruction while engaging the residents of the neighborhood.

To be authentic is to be true, and the truth in a city's language is found in its built heritage. This built heritage allows us to experience our culture and tradition through built form, rendering a city's distinctive identity visible. The authenticity of built heritage is especially important in an area such as the east end of Liberty Village, where the destructive character of modernity has erased almost all traces of Toronto's founding language. For this reason, the authenticity of original materials of the Toronto Central Prison is preserved to its fullest capacity under the veil of modernity.

Through combining the notions of modernity and authenticity this thesis proposes that the changes that are made to the new design over time are what link the two opposing notions on this site. What is contemporary today becomes part of the progressive authenticity of the prison chapel. 


\section{BIBLIOGRAPHY}

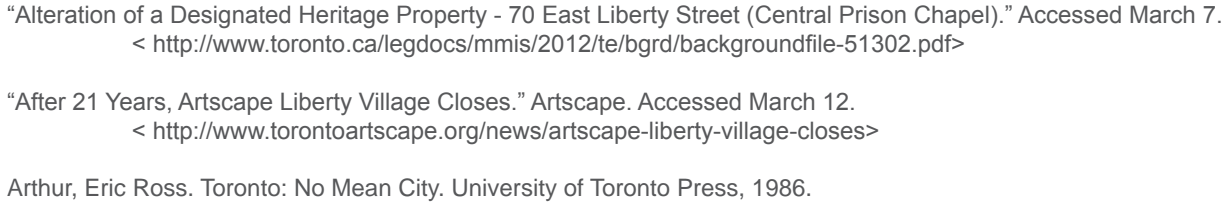

Charter, Venice. "International charter for the conservation and restoration of monuments and sites." In Second international congress of architects and technicians of historic monuments. 1964.

Conway, Daniel W., and Peter S. Groff, eds. Nietzsche: On morality. Vol. 3. Taylor \& Francis, 1998.

David Lowenthal, "Changing Criteria of Authenticity," in "An Introduction to Authenticity in Preservation", Pamela Jerome, APT Bulletin 39, no. 2/3, 2008

Downes, Brant William. Constructing the modern Ottoman waterfront: Salonica and Beirut in the late nineteenth century ProQuest, 2007.

E.R.A. Architects. Updated Stabilization Report: Condition Assessment. 2014

Frisby, David. Fragments of modernity: theories of modernity in the work of Simmel, Kracauer and Benjamin. Routledge, 2013

Geddes, Patrick. Cities in evolution. Vol. 27. London: Williams \& Norgate, 1949.

Guignon, Charles B. The existentialists: critical essays on Kierkegaard, Nietzsche, Heidegger, and Sartre. Rowman \& Littlefield Publishers, 2004.

Heynen, Hilde. Architecture and modernity: a critique. MIT press, 2000

Hvattum, Mari, and Christian Hermansen. Tracing modernity: manifestations of the modern in architecture and the city. Routledge, 2004.

Jacobs, Jane. The death and life of great American cities. Vintage, 1961.

Jerome, Pamela. "An introduction to authenticity in preservation." APT Bulletin39, no. 2/3 (2008): 3-7.

Juhani Pallasmaa, "Space, Place, Memory, and Imagination," in "Spatial Recall: Memory in Architecture and Landscape", Marc Treib, Taylor \& Francis Group, 2009

“King Liberty Village, Urban Design Guidelines." Accessed November 25, 2014. $<$ http://www1.toronto.ca/city_of_toronto/city_planning?community_planning/files/pdf/KingLiberty.pdf >

"Liberty Village Historical Facts." Accessed January 24, 2014.

< http://www.libertyvillagetoronto.com/liberty-village-historical-facts> 
Leakey, Felix William. Baudelaire: Les fleurs du mal. Cambridge University Press, 1992.

"Liberty Village BIA - BIA Listings - Business Improvement Areas / City of Toronto," Accessed February 4, 2015. <http://www1.toronto.ca/wps/portal/contentonly?vgnex-toid=6ad746aa794fa310VgnVCM10000071d60f89RCRD>

Lukacs, John. Democracy and populism: Fear \& hatred. Yale University Press, 2005.

Pevsner, Nikolaus. A History of Building Types. Princeton: Princeton University Press, 1976.

"Private Services Realty Ltd. Liberty Village, Toronto." Accessed January 23. http://www.psrbrokerage.com/neighborhoods/10015/liberty-village/>

Rousseau, Jean-Jacques. The Social Contract: And, the First and Second Discourses. Yale University Press, 2002.

Short, John Rennie. Globalization, modernity and the city. Routledge, 2013.

Stovel, Herb. "Origins and Influence of the Nara document on authenticity."APT Bulletin (2008): 9-17.

"The History of Toronto: An 11,000 Year Journey." Accessed November 16, 2014 <http://www1.toronto.ca/wps/portal/contentonly?vgnex-toid=ac418d577e312410VgnVCM10000071d60f89RCRD>

Taylor, Charles. The malaise of modernity. House of Anansi, 1991.

Taylor, Charles. Modern social imaginaries. Duke University Press, 2004.

Thompson, M. G. "Nietzsche and Psychoanalysis The Fate of Authenticity in a Postmodernist World." EXISTENTIAL ANALYSIS 15, no. 2 (2004): 203-217

Trieb, Marc. "Remembering Ruins, Ruins Remembering." Spatial Recall: Memory in Architecture and Landscape.

Vannini, Phillip, and J. Patrick Williams, eds. Authenticity in culture, self, and society. Ashgate Publishing, Ltd., 2009.

"What Liberty Village looked like before the condos." Accessed November 16, 2014 <http://www.blogto.com/city/2012/02/what_liberty_village_looked_like_before_the_condos/>

Wieditz, Thorben. "Liberty village: the makeover of Toronto's King and Dufferin Area." Centre for Urban and Community Studies, Toronto (2007). 


\title{
LIST OF ILLUSTRATIONS
}

\author{
IMAGE 1. "Young Tree Carved Inside Old Tree" My Modern Met. Accessed October 27, 2014 \\ < http://www.mymodernmet.com/profiles/blogs/guiseppe-penone-the-hidden-life-within> \\ IMAGE 2. Image by Author \\ IMAGE 3 . Kouros, about 530 B.C. or modern forgery, Dolomitic marble \\ $206.1 \times 54.6$ × $51 \mathrm{~cm}(811 / 8 \times 211 / 2 \times 201 / 16 \mathrm{in}$. $)$ \\ IMAGE 4 . \\ The J. Paul Getty Museum, Villa Collection, Malibu, California \\ IMAGE 5. Image by Author \\ IMAGE 6. Image by Author \\ IMAGE 7. "Greek Island Ferry Bookings." Greek Ferries. Accessed November 2, 2014 \\ < http://www.greekferries.gr/weather_greece/thessaloniki-en.htm> \\ IMAGE 8. "Castles of Thessaloniki." Kastrologos. Accessed November 2, 2014 \\ $<$ http://www.kastra.eu/castleen.php?kastro=thesniki> \\ IMAGE 9. "History of Thessaloniki." In Your Pocket. Accessed November 2, 2014 \\ < http://www.inyourpocket.com/greece/Thessaloniki/History-of-Thessaloniki_71841f> \\ IMAGE 10. "Hagia Sophia Thessaloniki." Geolocation. Accessed November 2, 2014 \\ < https://geolocation.ws/v/P/4819233/hagia-sophia-thessaloniki-selanik/en> \\ IMAGE 11. Charles Marville, Rue des Grans-Degrés, Paris, 1865-69. Albumen print, 304 x 266 mm. Courtesy Charles \\ Isaacs Gallery and Howard Greenberg Gallery, New York \\ IMAGE 12. Image by Author \\ IMAGE 13. Richard Roland Holst "Nederlands: Affiche. "Goethe's Faust”. N V Het Tooneel (Amsterdam). \\ Dir. Willem Royaards." Wikipedia. Accessed March 23, 2015 \\ < http://en.wikipedia.org/wiki/Scenes_from_Goethe\%27s_Faust> \\ IMAGE 14. "Living with Apollo and Dionysus." Mythic Stories. Accessed March 23, 2015. \\ < http://mythicstories.com/2013/05/02/living-with-apollo-and-dionysus/> \\ IMAGE 15. Unknown "A map of the Toronto Purchase." James Salmon Collection. \\ < http://en.wikipedia.org/wiki/File:Map_of_the_Toronto_purchase_\%28normal_orientation\%29.jpg> \\ IMAGE 16 . "City of Toronto compiled from surveys made to the present date, 1873." Copp, Clarck \& Co., Toronto City \\ Directory. Accessed on March 3, 2014 \\ < http://www.torontopubliclibrary.ca/detail.jsp?Entt=RDMDC-MAPS-R-73\&R=DCMAPS-R-73> \\ IMAGE 17. " "Church and Adelaide, 1911." Searching Toronto. Accessed December 3, 2014 \\ $<$ http://www.searchingtoronto.com/pictures/toronto-images/old-toronto-1800-1900s/slideshow/> \\ IMAGE 18. Image from Google Maps \\ IMAGE 19. "Clear sailing ahead for Distillery District?.” BlogTO. Accessed March 29, 2014. \\ IMAGE 20. \\ < http://www.blogto.com/city/2009/09/clear_sailing_ahead_for_distillery_district/> \\ IMAGE 21. Rendering of 60 Atlantic Avenue produced by Quadrangle Architects \\ IMAGE 22. "Liberty Village circa 1970." City of Toronto Archives, Series 3461, File 37, Item 26. \\ IMAGE 23. "Liberty Village circa 1970." City of Toronto Archives, Series 1465, File 37, Item 28 \\ IMAGE 24. Image by Author \\ IMAGE 25. Image by Author \\ IMAGE 26. Image by Author \\ IMAGE 27. Image by Author \\ IMAGE 28. Image by Author \\ IMAGE 29. City of Toronto Archives \\ IMAGE 30. City of Toronto Archives \\ IMAGE 31. City of Toronto Archives \\ IMAGE 32. City of Toronto Archives \\ IMAGE 33. Stephen R. Pile Architects \\ IMAGE 34. City of Toronto Archives \\ IMAGE 35. City of Toronto Archives \\ IMAGE 36. City of Toronto Archives \\ IMAGE 37. City of Toronto Archives
}


No. 1996-0378. A BY-LAW

To designate the property at 20 Strachan Avenue (Central Prison Chapel) as being of architectural and historical value or interest.

(Passed August 12, 1996.)

WHEREAS by Clause 3 of Neighbourhoods Committee Report No. 12, adopted by Council at its meeting held on August 12, 1996, authority was granted to designate the property at 20 Strachan Avenue (Central Prison Chapel) as being of architectural and historical value or interest;

AND WHEREAS the Ontario Heritage Act authorizes the Council of a municipality to enact by-laws to designate real property, including all the buildings and structures thereon, to be of historical or architectural value or interest;

AND WHEREAS the Council of The Corporation of the City of Toronto has caused to be served upon the owners of the land and premises known as No. 20 Strachan Avenue (Central Prison Chapel) and upon the Ontario Heritage Foundation Notice of Intention to designate the property and has caused the Notice of Intention to be published in a newspaper having a general circulation in the municipality once for each of three consecutive weeks as required by the Ontario Heritage Act;

AND WHEREAS the reasons for designation are set out in Schedule "B" to this by-law;

AND WHEREAS no notice of objection to the proposed designation has been served upon the Clerk of the municipality;

THEREFORE the Council of The Corporation of the City of Toronto enacts as follows:

1. The property at 20 Strachan Avenue (Central Prison Chapel), more particularly described and shown on Schedule "A" to this by-law, is being designated as being of architectural and historical value or interest.

2. The City Solicitor is authorized to cause a copy of this by-law to be registered against the property described in Schedules "A" and "C" to this by-law in the proper Land Registry Office.

3. The City Clerk is authorized to cause a copy of this by-law to be served upon the owner of the property at 20 Strachan Avenue (Central Prison Chapel) and upon the Ontario Heritage Foundation and to cause notice of this by-law to be published in a newspaper having general circulation in the City of Toronto as required by the Ontario Heritage Act.
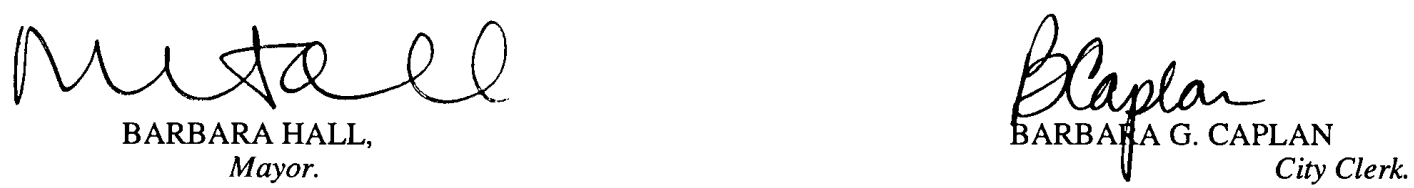

Council Chamber,

Toronto, August 12, 1996.

(L.S.)

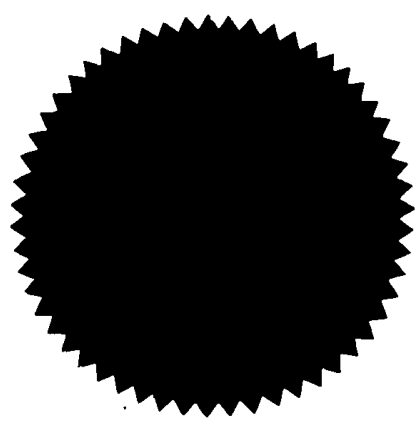




\section{SCHEDULE "A"}

In the City of Toronto, in the Municipality of Metropolitan Toronto and Province of Ontario, being composed of part of the Plan of the Ordnance Reserve (Block 11), known as the Central Prison Property, registered in the Land Registry Office for the Metropolitan Toronto Registry Division (No. 64), the boundaries of the land being described as follows:

PREMISING that the bearings hereinafter mentioned are grid and are referred to the Central Meridian 79 degrees and 30 minutes West Longitude through Zone 10 of the Ontario Co-ordinate System, NAD 27 (1974 adjustment), then;

COMMENCING at a point, the location of which may be arrived at as follows; 64R-13481;

BEGINNING at the most southerly angle of PART 4 on a plan of survey deposited as

THENCE north-easterly along a curve to the left having a radius of 106.68 metres, a distance of 6.84 metres to a point distant 6.84 metres measured on a course of North 65 degrees 35 minutes and 20 seconds East from the beginning of the said curve to the point of commencement;

THENCE continuing north-easterly along the said curve to the left having a radius of 106.68 metres, a distance of 2.82 metres more or less to the end of the said curve distant 2.82 metres measured on a course of North 62 degrees 59 minutes and 30 seconds East from the beginning of the said curve;

THENCE North 6 degrees 18 minutes and 15 seconds West, a distance of 12.06 metres;

THENCE North 83 degrees 43 minutes and 10 seconds East, a distance of 19.64 metres;

THENCE South 6 degrees 16 minutes and 50 seconds East, a distance of 7.77 metres;

THENCE South 83 degrees 43 minutes and 10 seconds West, a distance of 5.37 metres;

THENCE South 6 degrees 14 minutes and 00 seconds East, a distance of 17.04 metres;

THENCE South 83 degrees 46 minutes and 00 seconds West, a distance of 16.92 metres;

THENCE North 6 degrees 05 minutes and 00 seconds West, a distance of 11.74 metres more or less to the point of commencement.

The hereinbefore described land being delineated by heavy outline on Plan SYE2821 dated July 11,1996 , as set out in Schedule "C".

\section{SCHEDULE "B"}

Heritage Property Report

Basic Building Data:

Address:

Ward:

Current Name:
20 Strachan Avenue (southwest of corner of Strachan Avenue and East Liberty Street; see map, Attachment IIa)

3

not applicable 
CITY OF TORONTO BY-LAW

No. $1996-378$

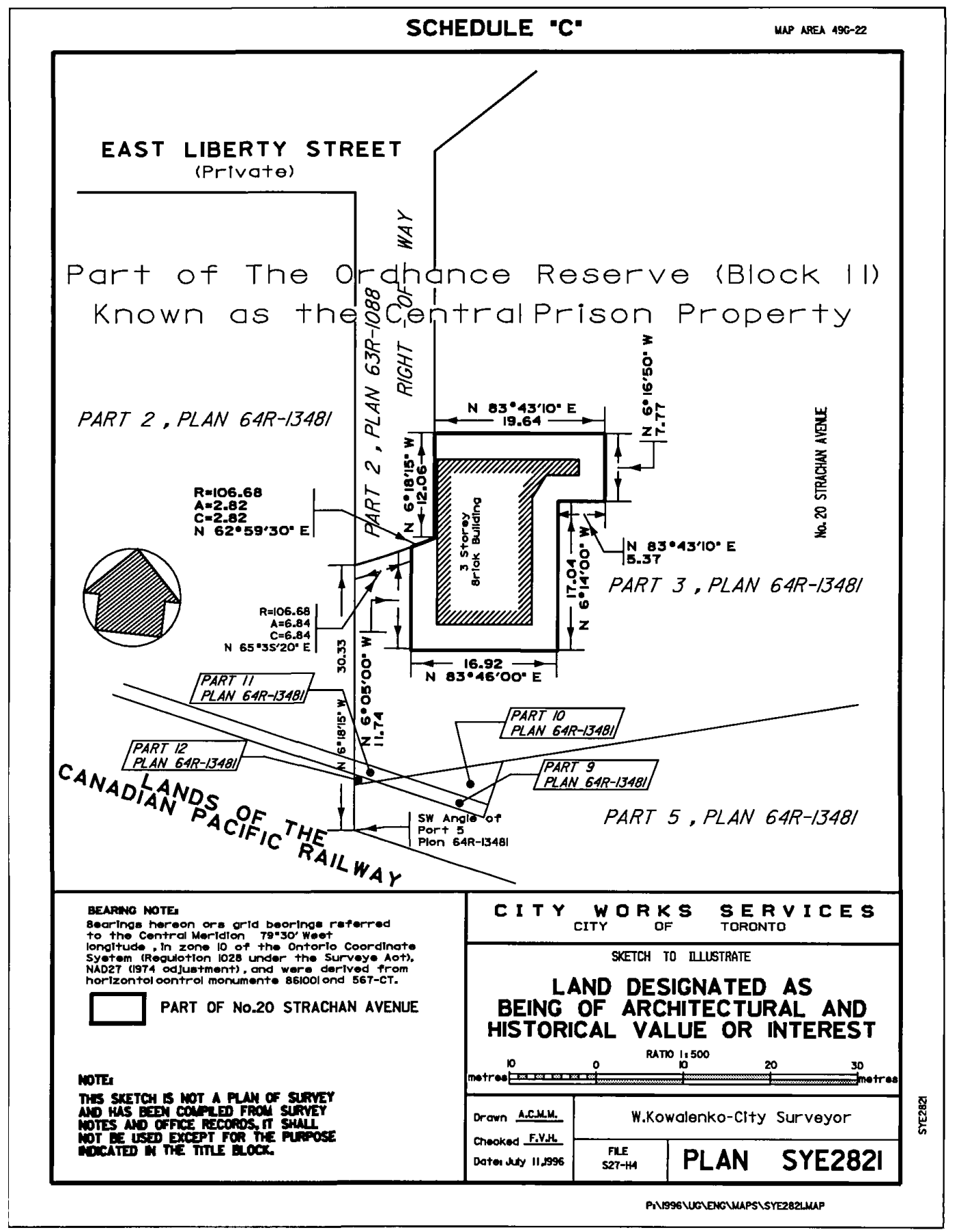



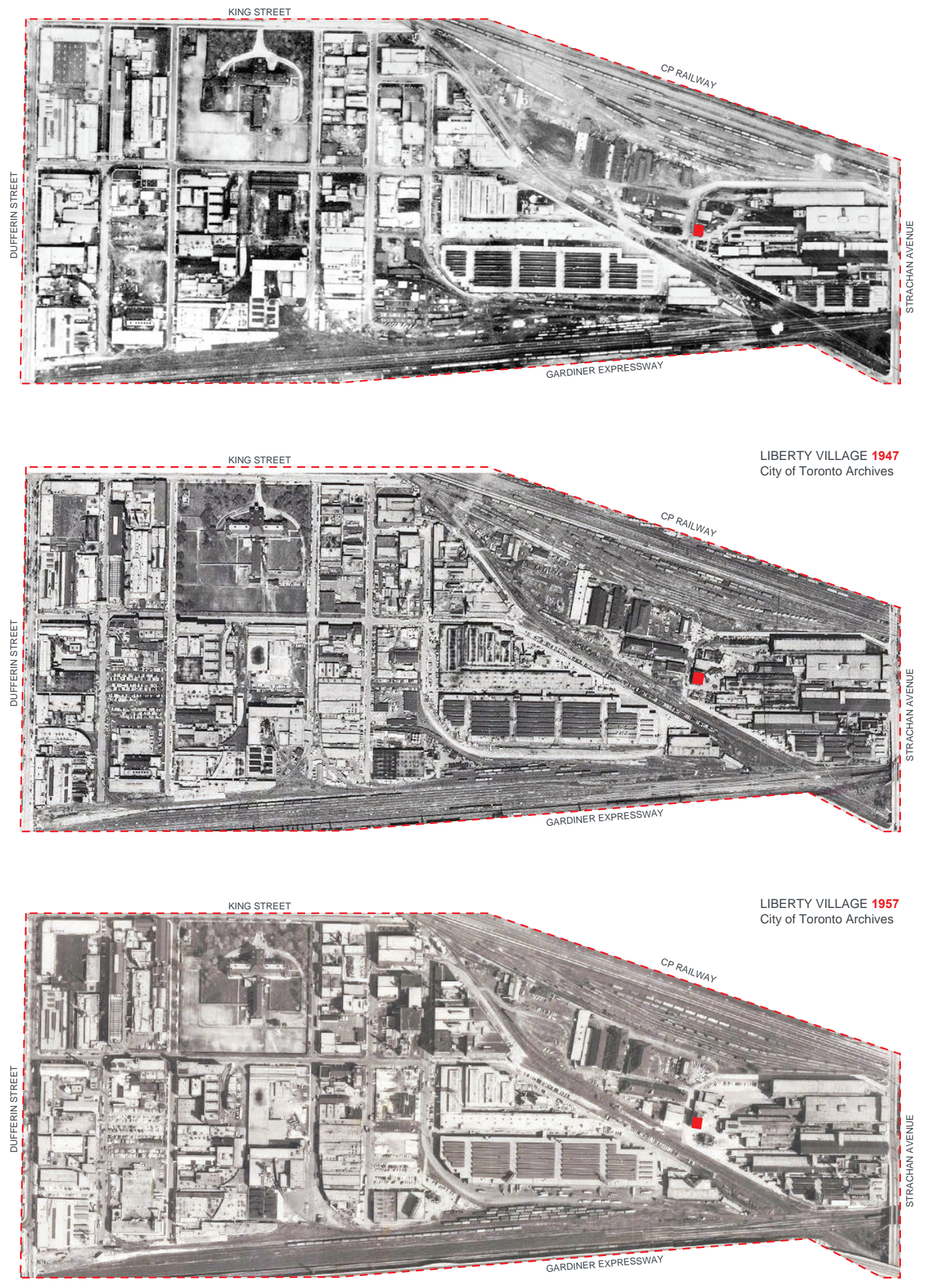

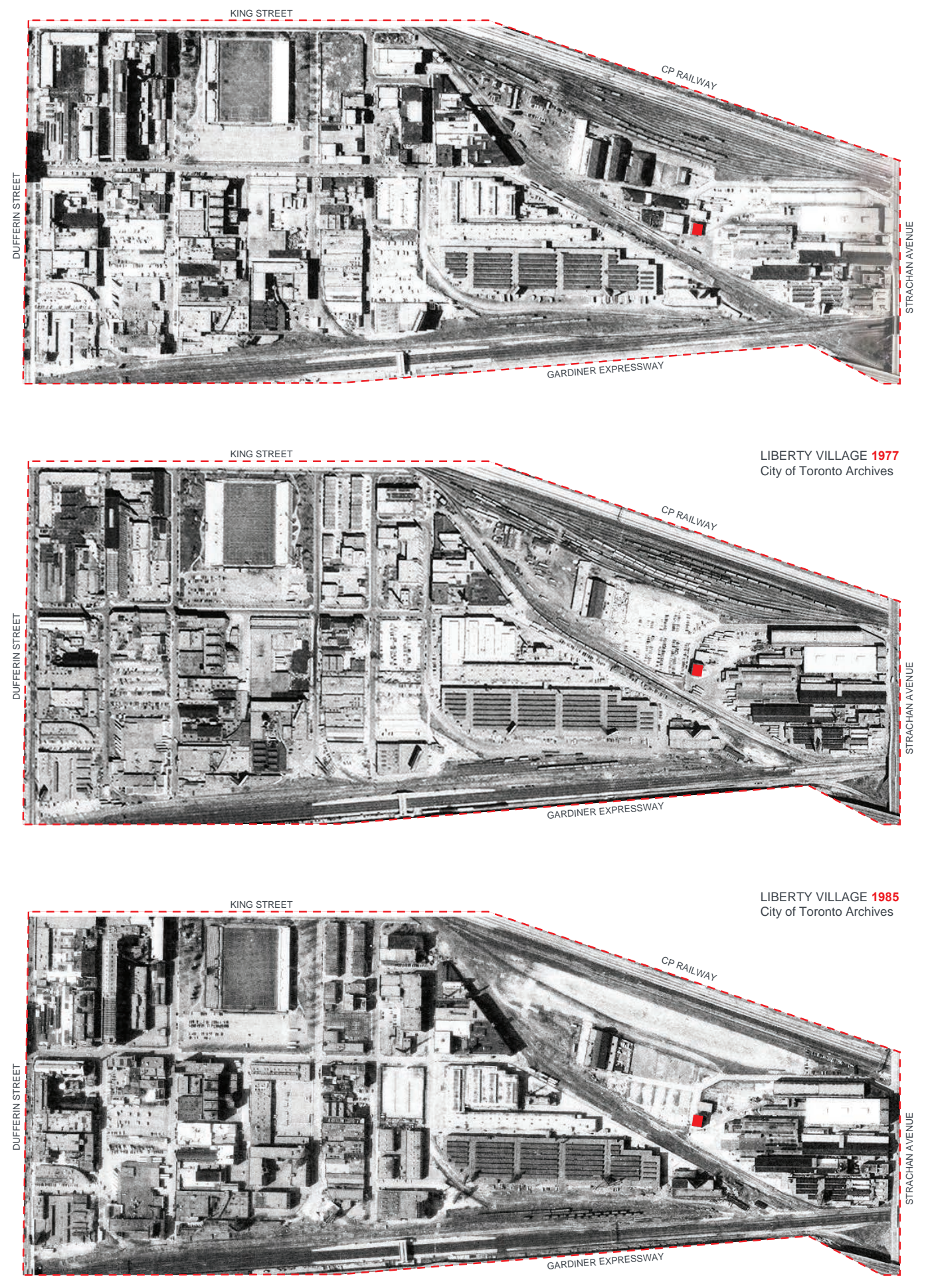